\title{
RESISTÊNCIA GENÉTICA, FUNGICIDAS E SOLARIZAÇÃO PARA O CONTROLE DE Thielaviopsis basicola (Berk. \& Broome) Ferraris NA CULTURA DE ALFACE (Lactuca sativa L.)
}

\author{
LILIANE DE DIANA TEIXEIRA - YAÑEZ
}

\begin{abstract}
Tese apresentada à Escola Superior de Agricultura "Luiz de Queiroz", Universidade de São Paulo, para obtenção do título de Doutor em Agronomia, Área de Concentração: Fitopatologia.
\end{abstract}

P I R A C I C A B A

Estado de São Paulo - Brasil

Fevereiro - 2005 


\title{
RESISTÊNCIA GENÉTICA, FUNGICIDAS E SOLARIZAÇÃO PARA O CONTROLE DE Thielaviopsis basicola (Berk. \& Broome) Ferraris NA CULTURA DE ALFACE (Lactuca sativa L.)
}

\author{
LILIANE DE DIANA TEIXEIRA - YAÑEZ \\ Engenheiro Agrônomo
}

Orientador: Prof. Dr. IVAN PAULO BEDENDO

Tese apresentada à Escola Superior de
Agricultura "Luiz de Queiroz", Universidade de
São Paulo, para obtenção do título de Doutor
em Agronomia, Área de Concentração:
Fitopatologia.

P I R A C I C A B A

Estado de São Paulo - Brasil

Fevereiro -2005 
Dados Internacionais de Catalogação na Publicação (CIP) DIVISÃO DE BIBLIOTECA E DOCUMENTAÇÃO - ESALQ/USP

Teixeira - Yañez, Liliane De Diana

Resistência genética, fungicidas e solarização para o controle de Thielaviopsis basicola (Berk. \& Broome) ferraris na cultura de alface (Lactuca sativa L.) / Liliane De Diana Teixeira - Yañez. - - Piracicaba, 2005.

103 p. : il.

Tese (Doutorado) - - Escola Superior de Agricultura Luiz de Queiroz, 2005.

Bibliografia.

1. Alface 2. Doença de planta 3. Efeito da temperatura 4. Fungicida 5. Matéria orgânica 6 . Solarização do solo 7 . Variedade resistente I. Título

CDD 635.52 
À incansável busca pela explicação do maior dos fenômenos: a vida, tão intensa e efêmera.

A meus pais JOSÉ ITACIL e LUIZA, pelo início de tudo Á MÁRCIA e GABRIEL, pela continuidade dos laços

À SANDRA, pela sincera amizade Ao DAVID, pelo amor incondicional 


\section{AGRADECIMENTOS}

Ao Prof. Dr. Ivan Paulo Bedendo, pela orientação e valiosa amizade.

Ao Prof. Dr. Hiroshi Kimati, pela excelente co-orientação e pela caríssima amizade, sempre disposto a amparar e auxiliar nos momentos pessoais mais difíceis.

Ao Prof. Dr. Cyro Paulino da Costa, pela excelente co-orientação, pelos conhecimentos transmitidos e por sua contagiante alegria de viver.

A todos os professores do departamento de Entomologia, Fitopatologia e Zoologia Agrícola da ESALQ / USP, pela importante colaboração em meu aperfeiçoamento profissional.

Ao prof. Dr. Carlos Tadeu dos Santos Dias, pelo auxílio nas análises estatísticas.

Ao Eng $^{\circ}$ Agrônomo Fernando César Sala, pela grande amizade, convivência agradável, generosidade e profissionalismo como companheiro de trabalho.

Aos amigos da pós-graduação da ESALQ, em especial Solange Bonaldo, Paulo Albuquerque e inúmeros outros que tornaram dias comuns em datas especiais e inesquecíveis. 
A todos os funcionários do departamento de Entomologia, Fitopatologia e Zoologia Agrícola da ESALQ / USP, pela amizade, atenção e presteza no auxílio, especialmente Sílvia, Heloísa, Edivaldo, Jéferson e Marina.

Aos funcionários do Departamento de Produção Vegetal da ESALQ / USP, pela grande colaboração na instalação, condução e avaliação dos ensaios in vivo, especialmente Rogério, Carlinhos e Aparecido.

Aos funcionários da biblioteca da ESALQ / USP, pela atenção dispensada.

A todos aqueles que colaboraram direta ou indiretamente e foram muito importantes para a realização deste trabalho. 


\section{SUMÁRIO}

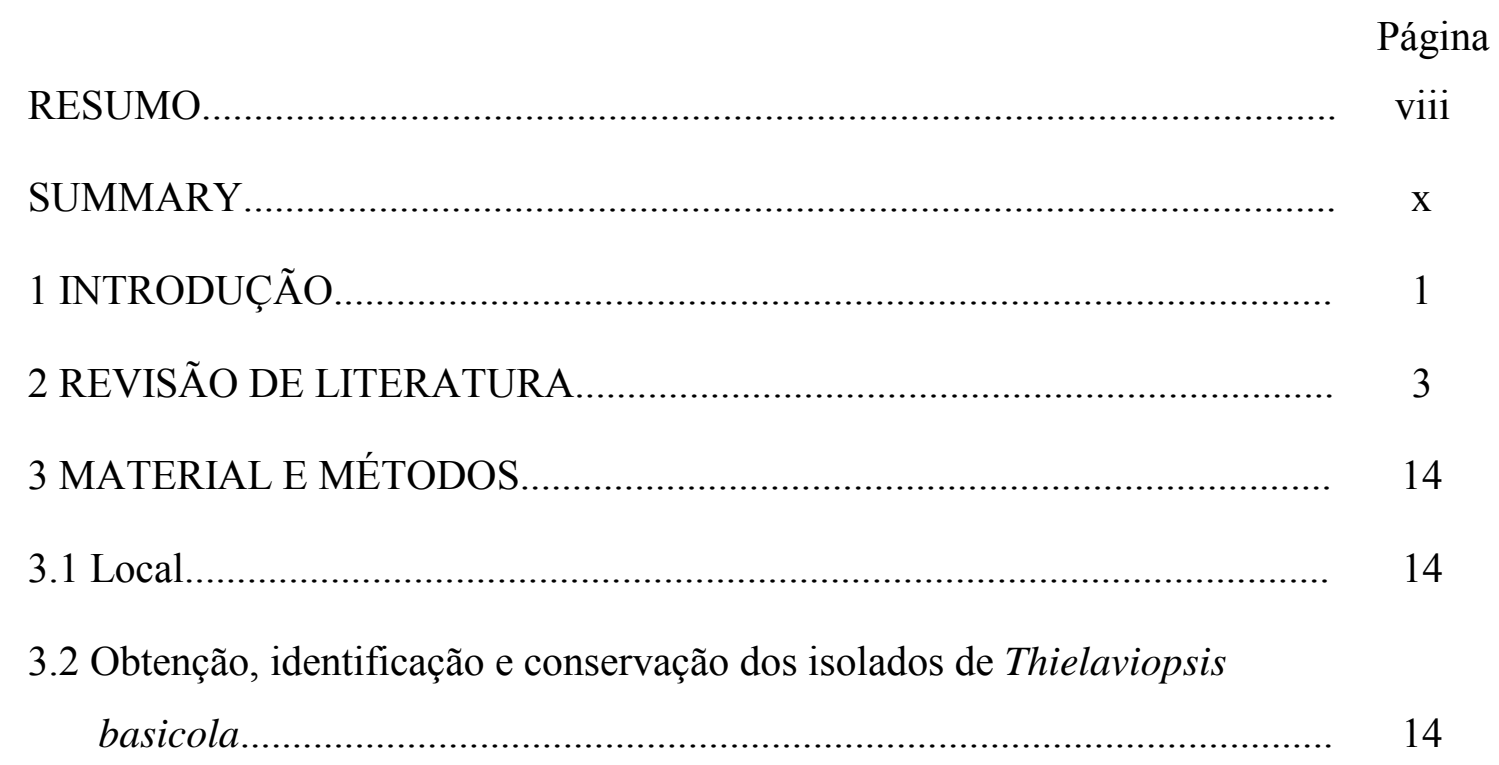

3.3 Efeito da temperatura sobre a patogenicidade in vitro de Thielaviopsis basicola...................................................................................... 15

3.3.1 Patogenicidade in vitro do isolado $L_{1}$ a várias cultivares de alface........... 15

3.3.2 Patogenicidade in vitro dos isolados de Thielaviopsis basicola................ 16

3.4 Reação de cultivares de alface a Thielaviopsis basicola............................. 16

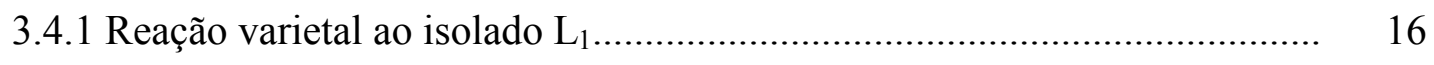

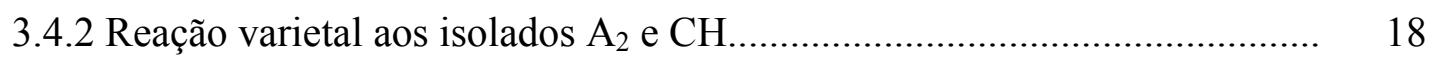

3.5 Efeito de fungicidas sobre o crescimento micelial e a esporulação de Thielaviopsis basicola.................................................................... 19 
3.6 Efeito de fungicidas no controle de Thielaviopsis basicola in vivo.

3.7 Efeito da solarização com e sem incorporação de matéria orgânica no controle de Thielaviopsis basicola em alface

4 RESULTADOS E DISCUSSÃO. 28

4.1 Obtenção dos isolados de Thielaviopsis basicola. 28

4.2 Efeito da temperatura sobre a patogenicidade in vitro de Thielaviopsis basicola...

4.2.1 Patogenicidade in vitro do isolado $\mathrm{L}_{1}$ a várias cultivares de alface. 30

4.2.2 Patogenicidade in vitro dos isolados de Thielaviopsis basicola

4.3 Reação de cultivares de alface a Thielaviopsis basicola.

4.3.1 Reação varietal ao isolado $\mathrm{L}_{1}$ 38

4.3.2 Reação varietal aos isolados $\mathrm{A}_{2}$ e $\mathrm{CH}$.

4.4 Efeito de fungicidas sobre o crescimento micelial e a esporulação de Thielaviopsis basicola.

4.5 Efeito de fungicidas no controle de Thielaviopsis basicola in vivo.

4.6 Efeito da solarização com e sem incorporação de matéria orgânica no controle de Thielaviopsis basicola em alface.

5 CONCLUSÕES

REFERÊNCIAS BIBLIOGRÁFICAS. 69

APÊNDICES 


\title{
RESISTÊNCIA GENÉTICA, FUNGICIDAS E SOLARIZAÇÃO PARA O CONTROLE DE Thielaviopsis basicola (Berk. \& Broome) Ferraris NA CULTURA DE ALFACE (Lactuca sativa L.)
}

\author{
Autora: LILIANE DE DIANA TEIXEIRA - YAÑEZ \\ Orientador: Prof.Dr. IVAN PAULO BEDENDO
}

\section{RESUMO}

A alface é a hortaliça folhosa mais consumida no Brasil. Seu cultivo vem sendo severamente afetado pelo fungo Thielaviopsis basicola, que ocasiona podridão radicular e subdesenvolvimento de plantas. Não existem maiores estudos sobre o controle desse patógeno nas condições brasileiras. Os objetivos deste trabalho foram: a determinação da ocorrência de T. basicola em plantios comerciais de alface e outras folhosas do Estado de São Paulo, do efeito da temperatura sobre a patogenicidade in vitro dos isolados obtidos e a avaliação da viabilidade de seu controle através do emprego de cultivares de alface resistentes, de fungicidas e da solarização, com e sem incorporação de matéria orgânica. Quatorze isolados de T. basicola foram obtidos de raízes necróticas de alface, chicória e rúcula. $\mathrm{O}$ efeito da temperatura sobre a patogenicidade in vitro dos isolados foi determinado, inoculando-se sementes de alface semeadas em agar-água. Foram realizados dois ensaios. No primeiro, quatorze cultivares de alface foram inoculadas com o isolado $\mathrm{L}_{1}$, a 21 e $30^{\circ} \mathrm{C}$. No segundo, a cv. Elisa foi inoculada com os 
quatorze isolados de $T$. basicola, a 21 e $27^{\circ} \mathrm{C}$. O isolado $\mathrm{L}_{1}$ foi mais agressivo a $21^{\circ} \mathrm{C}$ do que a $30^{\circ} \mathrm{C}$, ocasionando maiores severidade da doença e restrição do comprimento de plântulas em todas as cultivares. Todos os isolados causaram podridão radicular e reduziram o comprimento de plântulas a 21 e $27^{\circ} \mathrm{C}$, destacando-se o isolado $\mathrm{A}_{2}$ como o mais agressivo. De modo geral, os isolados foram mais agressivos a 27 que a $21^{\circ} \mathrm{C}$, exceto $\mathrm{L}_{1}$ e $\mathrm{L}_{2}$. A reação de cultivares de alface a três isolados de $T$. basicola foi avaliada in vivo. Primeiramente, treze cultivares foram confrontadas com o isolado $\mathrm{L}_{1} \mathrm{e}$, posteriormente, seis dessas cultivares foram inoculadas com os isolados $\mathrm{A}_{2}$ e $\mathrm{CH}$. As cultivares do tipo lisa foram suscetíveis e as do tipo crespa, resistentes, exceto a cv. Verônica. Quanto às cultivares do tipo americana, houve variação na reação ao patógeno. $\mathrm{O}$ efeito de fungicidas sobre o crescimento micelial e a esporulação in vitro foi determinado para três isolados de T. basicola. Nove fungicidas foram testados para o isolado $L_{1}$ e sete para os isolados $A_{2}$ e $C H$, nas concentrações de $0 ; 0,1 ; 1,10$ e 100 ppm de ingrediente ativo. $\mathrm{O}$ fungicida carbendazim foi o mais efetivo. A eficiência de sete fungicidas foi avaliada no controle de T. basicola in vivo. Todos os produtos testados foram eficientes, destacando-se o tebuconazole e o triadimenol. O controle de $T$. basicola através da solarização, associada ou não à incorporação de 10 ton / ha de torta de mamona ou de cama de frango, também foi avaliado. A solarização do solo com e sem incorporação de matéria orgânica controlou efetivamente o patógeno. Os melhores resultados foram obtidos com a incorporação da torta de mamona seguida de solarização, que permitiu a produção de plantas com maiores comprimento e massa fresca e evitou o aparecimento de qualquer sintoma de necrose radicular. 


\title{
GENETIC RESISTANCE, FUNGICIDES AND SOLARIZATION FOR THE CONTROL OF Thielaviopsis basicola (Berk. \& Broome) Ferraris IN LETTUCE CROP (Lactuca sativa L.)
}

\author{
Author: LILIANE DE DIANA TEIXEIRA - YAÑEZ \\ Adviser: Prof. Dr. IVAN PAULO BEDENDO
}

\section{SUMMARY}

Lettuce is the most used leafy vegetable in Brazil. Its crop is being severely affected by Thielaviopsis basicola, fungus which causes root rot and stunting in plants. There are no control studies about this pathogen for the brazillian conditions. This research aimed: to determine the T. basicola occurence in São Paulo State commercial lettuce and other leafy vegetables crops, the temperature effect on isolates pathogenicity in vitro and control viability evaluation by lettuce resistant varieties, fungicides and solarization with and without organic matter amendments. Fourteen $T$. basicola isolates were got from lettuce, chicory and arugula necrotic roots. Temperature effect on the isolates pathogenicity in vitro was determined in inoculated seeds sown on the surface of water agar medium. Two trials were carried out. In the first one, fourteen lettuce varieties were inoculated with $\mathrm{L}_{1}$ isolate at 21 and $30^{\circ} \mathrm{C}$. In the second, only cv. Elisa was inoculated with fourteen $T$. basicola isolates, at 21 and $27^{\circ} \mathrm{C}$. The isolate $\mathrm{L}_{1}$ was the most aggressive at $21^{\circ} \mathrm{C}$ than $30^{\circ} \mathrm{C}$, causing higher disease severity and seedling length restriction of all varieties. All isolates induced root rot and reduced seedlings length 
at 21 and $27^{\circ} \mathrm{C}$, but $\mathrm{A}_{2}$ isolate was the most aggressive one. All isolates were more aggressive at 27 rather than $21^{\circ} \mathrm{C}$, except $\mathrm{L}_{1}$ and $\mathrm{L}_{2}$ isolates. Lettuce varieties reactions to three T. basicola isolates were evaluated in vivo. First about thirteen varieties were challenged with $\mathrm{L}_{1}$ isolate and later, six of them were inoculated with $\mathrm{A}_{2}$ and $\mathrm{CH}$ isolates. Butterhead types were susceptible and Grand Rapids types were resistant, except cv. Veronica. Iceberg type varieties varied in their reaction to pathogen. Fungicide effect on mycelial growth and sporulation in vitro was determined for three $T$. basicola isolates. Nine fungicides were tested for $\mathrm{L}_{1}$ isolate and seven for $\mathrm{A}_{2}$ and $\mathrm{CH}$ isolates, at concentrations of $0 ; 0,1 ; 1 ; 10$ and $100 \mathrm{ppm}$ of active ingredient. Carbendazim was the most effective. Seven fungicides efficacy was evaluated to control of T. basicola in vivo. All tested products were efficient, but tebuconazole and triadimenol were the best ones. The control of T. basicola through soil solarization with and without chicken litter and coarse castor bean meal amendments, at 10 ton / ha, also was evaluated. Soil solarization alone and combined with organic matter amendments were both effective ways to control the pathogen. The best results were got with incorporation of coarse castor bean meal followed by solarization, which allowed increase in fresh weight and length of plants, and avoided root rot symptoms. 


\section{INTRODUÇÃO}

A alface (Lactuca sativa L.), provavelmente originária da região mediterrânea, é conhecida e cultivada há milhares de anos (Davis et al., 1997). Acredita-se que foi introduzida no Brasil pelos portugueses, no século XVI, tornando-se, atualmente, a hortaliça folhosa mais consumida pelos brasileiros (Ceasa-Campinas, 2002). É uma espécie hortícola também muito atrativa aos horticultores, porque possui ciclo curto e alta produtividade, além de ser cultivada durante todo o ano, graças à adaptabilidade de suas variedades a diferentes condições climáticas.

De acordo com o IBGE (1996), a produção nacional de alface é de aproximadamente 312.000 toneladas / ano. Apenas no estado de São Paulo ocupa uma área de 7859 ha, com uma produtividade de 137.000 toneladas / ano, gerando mais de 6.000 empregos diretos (Ceasa-Campinas, 2002).

As doenças ocasionadas por patógenos habitantes do solo são as mais limitantes para o cultivo de alface. Além de inutilizarem comercialmente toda a planta, comprometem a área para plantios posteriores (Lopes \& Quezado-Duval, 1998). Pythium spp., Sclerotinia minor Jagger, Sclerotinia sclerotiorum (Lib.) de Bary, Rhizoctonia solani Kühn e Thielaviopsis basicola (Berk. \& Broome) Ferraris são os patógenos radiculares que causam maiores prejuízos para a cultura no Brasil (Lopes \& Quezado-Duval, 1998; Pavan \& Kurozawa, 1997; Teixeira-Yañez et al., 2003). Pesquisas visando o controle desses patógenos têm sido desenvolvidas (Barros et al., 2004; Ferreira, 2000; Sinigaglia et al., 2001), com exceção de T. basicola. Apesar de um fungo do gênero Thielaviopsis já ter sido constatado em nosso país, atacando plântulas de alface (Silva et al., 1999), não existem maiores estudos a seu respeito. 
A podridão negra das raízes de alface, ocasionada por $T$. basicola, tem sido freqüentemente diagnosticada na Clínica Fitopatológica da ESALQ/USP. Vem causando grandes prejuízos aos produtores, principalmente no estado de São Paulo.

Dessa forma, frente a total escassez de informações sobre o controle de $T$. basicola, que acomete cultivos brasileiros de alface, foi realizada a presente pesquisa, que teve por objetivos: a determinação da incidência de $T$. basicola em plantios comerciais de alface no Estado de São Paulo, a verificação do efeito da temperatura sobre a patogenicidade in vitro dos isolados obtidos e a avaliação da viabilidade de seu controle através do emprego de cultivares resistentes, do uso de fungicidas e da solarização do solo, associada ou não à incorporação de torta de mamona ou de cama de frango. 


\section{REVISÃO DE LITERATURA}

A alface, planta da família Asteraceae, está sujeita à ocorrência de diversas doenças. Aproximadamente 75 doenças de origem biótica já foram registradas incidindo sobre a cultura em todo o mundo (Lopes \& Quezado-Duval, 1998). A ocorrência de Thielaviopsis basicola causa sérios prejuízos na produção não apenas de alface (O'Brien \& Davis, 1994; Punja \& Chittaranjan, 1994), mas também de outras importantes culturas como citros (Citrus spp.) (Tsao \& Van Gundy, 1962), algodão (Gossypium hirsutum L.) (Mathre et al., 1966), amendoim (Arachis hypogaea L.) (Hsi, 1967), fumo (Nicotiana tabacum L.), feijão (Phaseolus vulgaris L.), cenoura (Daucus carotae L.), pepino (Cucumis sativus L.) e melancia (Citrullus lanatus (Thunb.) Matsum. \& Nakai) (Chupp \& Sherf, 1960; O'Brien \& Davis, 2002). O patógeno apresenta ampla gama de hospedeiros, causando podridão radicular em mais de 137 espécies de plantas, inclusive na planta daninha Sonchus oleraceus L., que é sua hospedeira natural.

Segundo O'Brien \& Davis (2002), as plantas de alface infectadas pelo patógeno apresentam, inicialmente, lesões amarronzadas nas raízes principais, que vão aumentando em tamanho e posteriormente assumem coloração enegrecida. Ocorre acentuada redução do crescimento e, nos momentos mais quentes do dia, as plantas murcham. Freqüentemente, suas raízes laterais são completamente destruídas. Quando a infecção se dá no início do desenvolvimento, observa-se tombamento seguido de morte.

Thielaviopsis basicola é um fungo mitospórico, da classe dos Hyphomycetes,

que não apresenta estágio sexual (ou teleomorfo) conhecido. Produz dois tipos de esporos, o clamidósporo, que é pigmentado e apresenta parede espessa e o conídio (ou 
endoconídio) que é menor em tamanho, hialino e originado endogenamente, em cadeias,a partir de células conidiógenas denominadas fiálides. Devido a sua natureza pleomórfica, sucedem problemas em sua nomenclatura, sendo referido por muitos pesquisadores pelo nome de seu sinanamorfo Chalara elegans Nag Raj \& Kendrick. Essa discordância decorre do fato de que em sua descrição original, feita por Berkeley \& Broome $(1850)^{1}$ citados por Shew \& Meyer (1992), como Torula basicola, apenas um tipo de esporo, o clamidósporo, foi levado em consideração. Por outro lado, como o fungo também produz conídios característicos do gênero Chalara, foi incluído nesse gênero por Nag Raj \& Kendrick (1975), constituindo uma nova espécie: C. elegans. Entretanto, essa espécie somente representa o estágio conidial do organismo. No presente trabalho, foi adotada a denominação Thielaviopsis basicola, de acordo com as recomendações de Shew \& Meyer (1992).

Os esporos de T. basicola são produzidos em número abundante e podem ser disseminados através de muda e solo contaminados, pelo vento e água de irrigação ou drenagem. O clamidósporo é um propágulo mais rústico, resistente e é capaz de sobreviver durante longos períodos de tempo (pelo menos de três a cinco anos) dormente no solo mas também em solos ou chão de estufas, bancadas, máquinas e ferramentas utilizadas para cultivo num estado dessecado (Trebilco et al., 2002). Já os conídios, podem ser transportados pelo vento a distâncias relativamente curtas, sendo facilmente recuperados a partir de poeira e água de drenagem de viveiros contaminados (Graham \& Timmer, 1991; Trebilco et al., 2002).

O patógeno é encontrado tanto em solos cultivados como em não cultivados, em patossistemas selvagens e agrícolas (Trebilco et al., 2002), podendo naturalmente surgir uma linhagem patogênica. Entretanto, há fortes suspeitas de sua introdução em cultivos comerciais no Brasil, através de substratos a base de turfa contaminados. Graham \& Timmer (1991) demonstraram a importância de substratos a base de turfa como fonte de inóculo de T. basicola em viveiros de citros na Flórida. O'Brien \& Davis (1994) isolaram T. basicola de mudas de alface produzidas em substratos contendo turfa,

\footnotetext{
${ }^{1}$ BeRKELEY, M.J.; BROOME, C.E. Notices of Britishi fungi. Ann. Mag. Nat. Hist. Ser, v.2, n.5, p.455-466, 1850.
} 
antes de terem sido transplantadas para o campo. Os autores atribuíram a ampla distribuição e alta severidade da podridão negra da raiz em alface, na Austrália, entre 1990 e 1992 à utilização de substrato contaminado com o patógeno.

Pequenos dípteros vulgarmente conhecidos como "fungus gnats" e "shore flies", freqüentemente encontrados no Brasil, também podem ser responsáveis pela disseminação de T. basicola, particularmente em cultivos protegidos de alface. As larvas desses insetos alimentam-se de algas e também de raízes de plantas. Se essas raízes estiverem infectadas, o fungo passa através do trato digestivo dos insetos e durante a defecação dos adultos, em plantas sadias, os esporos liberados são capazes de germinar e dar início à nova infecção (Trebilco et al., 2002).

No Brasil, uma espécie de Thielaviopsis foi relatada pela primeira vez ocasionando problemas na cultura de alface recentemente no estado do Rio de Janeiro (Silva et al., 1999). Anteriormente, o patógeno foi considerado de menor importância na América Latina (Abawi, 1991), provavelmente pelo fato de não ter sido identificado corretamente. Comumente foi confundido com distúrbios de origem fisiológica como injúrias ocasionadas por fertilizantes, excesso de frio ou calor, irrigação em demasia ou insuficiente (Trebilco et al., 2002). Além disso, seu isolamento direto apresenta maior dificuldade que outros patógenos radiculares. Atualmente, vários produtores paulistas de alface estão tendo enormes prejuízos devido à podridão radicular ocasionada por $T$. basicola, conforme constatado na Clínica Fitopatológica da Escola Superior de Agricultura "Luiz de Queiroz" - ESALQ/USP. Dessa forma, maiores estudos a respeito desse patógeno nas condições brasileiras são de extrema importância para que propostas de controle possam ser recomendadas.

Existe uma marcante correlação entre densidade de inóculo de T. basicola no solo e severidade de podridão negra da raiz em diversas culturas, que tem sido demonstrada por vários autores (Bhatti \& Kraft, 1992a; Holtz \& Weinhold, 1994; Meyer \& Shew, 1991; Tabachnik et al., 1979). Entretanto, diversos fatores ambientais e culturais influenciam essa relação, como temperatura ambiente, resistência genética do hospedeiro, temperatura, umidade e propriedades químicas do solo. 
A severidade de T. basicola geralmente é maior em plantas cultivadas sob condições adversas de temperatura. Diversos relatos na literatura evidenciam que a amplitude de temperatura adequada para o desenvolvimento da doença normalmente é subótima ao crescimento do hospedeiro (Abawi, 1991; Adams, 1971; Bateman \& Dimock, 1959; Lloyd \& Lockwood, 1963). Entretanto, Bhatti \& Kraft (1992a) estudando a influência da temperatura e densidade de inóculo sobre a podridão negra da raiz de grão-de-bico (Cicer arietinum L.), observaram que a doença foi mais severa na temperatura de $30^{\circ} \mathrm{C}$, maior que a faixa de temperatura ideal para o crescimento do hospedeiro. O'Brien \& Davis (1994), trabalhando com uma estirpe altamente patogênica, isolada de alface, constataram que o crescimento ótimo do patógeno ocorre entre 23 e $26^{\circ} \mathrm{C}$. Os autores consideraram que o fungo é adaptado às temperaturas mais elevadas daquela região subtropical.

Maior umidade do solo, além de ser favorável ao desenvolvimento das plantas cultivadas, favorece também a atividade patogênica de T. basicola. De acordo com Bhatti \& Kraft (1992b) o aumento da umidade do solo agravou a severidade da podridão negra da raiz em grão-de-bico. Solos com déficit hídrico prejudicam a germinação dos esporos do fungo. Solos saturados em umidade, por apresentarem condições muito próximas à anaerobiose, são prejudiciais ao sistema radicular das plantas, podendo torná-las predispostas ao patógeno.

Assim, a manipulação das condições ambientais deve fazer parte de programas integrados para o manejo da doença.

$\mathrm{O}$ uso de cultivares resistentes é o meio mais efetivo, prático e barato para o controle da podridão negra da raiz incitada por T. basicola. Segundo Hood \& Shew (1996) dois tipos de resistência genética têm sido utilizados para o controle da doença na cultura do fumo. Há uma resistência baixa a moderada e parcial derivada de Nicotiana tabacum L. e outra resistência completa, regulada por apenas um gene, derivada de Nicotiana debneyi L. Esta resistência completa é utilizada em fumo desde a década de 1950, nos EUA. Parece ser durável, pois ainda não foi constatado nenhum isolado ocasionando a doença em cultivares que possuem esse gene. 
Sala et al. (2004a), estudando a herança da reação de alface a T. basicola, constataram que a resistência é controlada por um gene dominante e sugeriram a designação $T b$ para esse gene.

Meyer \& Shew (1991) verificaram o efeito da resistência genética do hospedeiro sobre a relação entre densidade de inóculo de T. basicola e a severidade da podridão negra da raiz de fumo. Populações do patógeno menores que 50 unidades formadoras de colônia (u.f.c.) / g de solo ocasionaram alta severidade da doença em 52 $\%$ das plantas com baixa resistência (cv. B21xKy10) e em somente $3 \%$ das plantas com moderada resistência (cv. Ky14). Entretanto, a severidade da doença foi similar para ambas cultivares avaliadas quando foram submetidas à uma alta pressão do patógeno.

O'Brien \& Davis (1994) ao examinarem a reação de diversas cultivares de alface ao patógeno, constataram grande variabilidade. Esse fato foi surpreendente, pois se desconhecem pesquisas visando resistência ao patógeno em alface. As cultivares Kirralee e Monaro mostraram-se resistentes enquanto Classic, Yatesdale e Buffalo foram altamente suscetíveis.

Como existe grande carência de cultivares de alface, dos vários segmentos varietais, altamente resistentes a $T$. basicola, o uso de cultivares suscetíveis ou com moderada resistência associado ao tratamento com um fungicida adequado pode proporcionar satisfatório controle da podridão negra da raiz de alface (O'Brien \& Davis, 1994).

Segundo Papavizas et al. (1972), de 41 fungicidas voláteis e não voláteis avaliados no controle de T. basicola nas culturas de feijão e fumo, apenas benomyl, thiabendazole, thiabendazole + ETMT (5-ethoxy-3-trichloromethyl-1,2,4-thiadiazole), maneb, captan, MSNB (2-methylsulfonyl-6-nitrobenzothiazole), DMTT (tetrahydro-2H3,5-dimethyl-1,3,5-thiadiazine-2-thione) e SMDC (sodium N-methyldithiocarbamate) reduziram eficientemente a severidade da doença, em condições de casa-de-vegetação, quando aplicados como rega, nas concentrações de 50 e 100 ppm.

Tosi \& Zazzerini (1992) pesquisaram a eficiência da rega com benomyl, triadimenol, fosetyl-Al e tolclofos-methyl na redução da severidade da podridão negra da raiz de fumo, em casa-de-vegetação. Os autores verificaram que as aplicações de 
benomyl, a $30 \mathrm{ppm}$ no momento da semeadura e de triadimenol, a 10 e $20 \mathrm{ppm}, 15$ dias antes, reduziram significativamente a severidade da doença. Fosetyl-Al e tolclofosmethyl, empregados na concentração de $50 \mathrm{ppm}$ na semeadura, foram ineficientes.

O'Brien \& Davis (1994) estudaram o efeito de benomyl e propiconazole sobre o crescimento micelial de quatro isolados de Chalara spp. Dois de C. elegans (sinanamorfo: Thielaviopsis basicola) de alface e dois de C. paradoxa (De Seynes) Sacc. (sinanamorfo: T. paradoxa (De Seynes) Höhn), um de fruto de abacaxi (Ananas comosus L. Merril) e um de fruto de banana (Musa x paradisiaca L.). Isolados de C. paradoxa foram relativamente mais sensíveis aos fungicidas que os de C. elegans. A completa inibição do crescimento micelial foi atingida com $0,1 \mathrm{ppm}$ de benomyl para as duas espécies; $0,01 \mathrm{ppm}$ de propiconazole para C. paradoxa e $1 \mathrm{ppm}$ de propiconazole para C. elegans. Os pesquisadores também avaliaram o controle da podridão negra da raiz de alface, em casa-de-vegetação, pelos dois fungicidas e constataram a eficácia da rega, logo após o transplante das mudas, com benomyl $(500 \mu \mathrm{g}$ i.a. $/ \mathrm{mL})$ e propiconazole (125 $\mu$ g i.a. $/ \mathrm{mL})$. Entretanto, no tratamento com propiconazole, ocorreu leve distorção no crescimento das plantas.

Entre inúmeros fungicidas testados para o controle da podridão negra da raiz em diversas culturas, o benomyl destacou-se em várias pesquisas (Gayed, 1969; Hsi \& Ortiz Jr., 1980; Manning et al., 1970; Saenger, 1970), além daquelas anteriormente citadas. Entretanto, esse fungicida foi retirado do mercado.

A ocorrência de podridão negra da raiz incitada por T. basicola também é influenciada por diversos fatores edáficos. Valores baixos de $\mathrm{pH}(\leq 5,6)$, altos teores de amônia e alumínio trocável e uma baixa saturação de bases diminuem a severidade da doença (Chun \& Lockwood, 1985; Copes \& Hendrix, 1996; Meyer et al., 1994; Meyer $\&$ Shew, 1991).

Meyer \& Shew (1991) constataram em experimentos de campo, que não houve desenvolvimento de podridão negra da raiz tanto em cultivar suscetível (B21xKy10) como moderadamente resistente de fumo (Ky14), em solos com valores de $\mathrm{pH}$ inferiores a 5,2, embora o patógeno estivesse presente em densidades suficientes para ocasionar a doença (> 50 u.f.c. / g de solo). Entretanto, ocorreu a expressão da doença, em ambas 
cultivares, em solos com pH inferior a 5,2, mas que apresentavam saturação de bases superior a $70 \%$. Em outro ensaio feito sob condições controladas, solos ácidos provenientes de campos de cultivo de fumo foram fumigados e reinfestados artificialmente com T. basicola. A supressão a doença foi confirmada nessas condições, sendo revertida após a realização da calagem para aumentar o pH da solução do solo e a saturação de bases. O mecanismo de interação entre o desenvolvimento da doença e o $\mathrm{pH}$ da solução do solo não foi ainda totalmente elucidado. $\mathrm{O}$ efeito do $\mathrm{pH}$ pode ser derivado de sua influência sobre outros fatores. A liberação de cátions adsorvidos e a absorção pelas raízes das plantas são parcialmente determinadas pelo $\mathrm{pH}$. Como a saturação de bases é um indicativo dos níveis de cátions base (principalmente $\mathrm{Ca}$ ) ou ácidos (principalmente $\mathrm{Al}$ ) disponíveis no solo, acredita-se que a virulência do patógeno pode ser afetada por baixos níveis de cálcio ou altos níveis de alumínio trocável. Maiores estudos são necessários para que essa relação possa ser esclarecida.

A forma e a concentração de nitrogênio no solo também afetam o desenvolvimento de doenças de plantas, quer atuando sobre o patógeno, quer alterando a resistência do hospedeiro (Huber \& Watson, 1974). O nitrogênio no solo está relacionado ao $\mathrm{pH}$; em valores baixos de $\mathrm{pH}$, ocorre a redução dos processos de amonificação e nitrificação; a absorção radicular de amônio acidifica e a de nitrato neutraliza o pH da solução do solo, especialmente na região da rizosfera das plantas. Copes \& Hendrix (1996), ao pesquisar a influência de proporções de $\mathrm{NO}_{3} / \mathrm{NH}_{4}$ sobre a ocorrência de T. basicola em Viola $x$ wittrockiana, constataram que a forma de nitrogênio afeta o desenvolvimento da doença e observaram uma diminuição de 56 \% na incidência, quando as proporções de $\mathrm{NO}_{3} / \mathrm{NH}_{4}$ estiveram entre 1:0 e 1:3. O crescimento das plantas inoculadas foi maior quando as proporções de $\mathrm{NO}_{3} / \mathrm{NH}_{4}$ foram 3:1, 2:1 ou 1:1 e a doença apresentou uma severidade moderada nas proporções de 2:1 e 1:1. A menor incidência ocorreu com altos teores de $\mathrm{NH}_{4}$, porém, o crescimento das plantas também foi inibido. Os maiores pesos de raiz e de parte aérea e número de flores em plantas não inoculadas sucederam na proporção de 3:1 de $\mathrm{NO}_{3} / \mathrm{NH}_{4}$. Todavia, nessa mesma proporção, o desenvolvimento das plantas inoculadas foi reduzido devido à alta incidência da doença. 
Com o intuito de diminuir a contaminação ambiental e evitar resíduos tóxicos nos alimentos, métodos alternativos de controle de patógenos veiculados pelo solo têm sido desenvolvidos.

A solarização é uma técnica de tratamento em solo umedecido, coberto por um filme plástico transparente e exposto à luz do sol durante os meses com altas radiações.

Comparada com a fumigação química ou com o tratamento a vapor, a solarização é considerada como relativamente amena em relação a modificações no solo (Souza, 1994). Esta metodologia não promove temperaturas tão altas como é o caso do uso do vapor (Katan, 1981). Entretanto, a solarização envolve um processo hidrotérmico que atua no solo durante algumas semanas com temperaturas flutuando diariamente. Isto faz com que alterações químicas e biológicas sejam observadas, como o incremento na concentração de certos nutrientes minerais solúveis (Chen \& Katan, 1980). Quando o solo é solarizado, grande parte da microbiota residente é morta e degradada liberando assim, nutrientes, os quais, a seguir, voltam a compor a solução do solo.

Durante a fase de solarização, a combinação de altas temperaturas e umidade, principalmente em solos com alto teor de matéria orgânica, resulta na morte de muitos tipos de microorganismos, incluindo os nitrificadores, resultando em condições microaeróbicas favoráveis ao acúmulo de $\mathrm{NH}_{4} \mathrm{~N}$ (Souza, 1994). Além do nitrogênio, outros nutrientes minerais, como o fósforo, potássio e cálcio mais magnésio foram encontrados algumas vezes em altas concentrações após a solarização (Lefèvre \& Souza, 1993).

Em função das temperaturas não muito altas alcançadas durante o processo de solarização, o efeito da aplicação desta técnica sobre a microbiota do solo pode ser considerado seletivo, pois fungos, bactérias e actinomicetos termotolerantes e termofilicos podem sobreviver, e suas populações podem até aumentar (Gamliel et al., 1989), enquanto a maioria dos patógenos habitantes do solo podem ser inativados, pois são mesofílicos (Bollen, 1969). O efeito letal da solarização é mais pronunciado em microrganismos que não são bons competidores no solo. Muitos patógenos de plantas se enquadram neste grupo, já que os mesmos apresentam requerimentos fisiológicos 
especializados que os condicionam a uma maior adaptação para uma coexistência com o hospedeiro (Souza, 1994).

Com a retirada do plástico, após a solarização, o solo apresenta um "vácuo biológico", que é ocupado pelos microorganismos mais competitivos. Assim, populações de antagonistas como Bacillus spp., Pseudomonas fluorescens e fungos termotolerantes passam a ser prevalentes, resultando em uma suspensão da recolonização pelo patógeno (Gamliel et al., 1989).

Um fenômeno frequentemente observado em solos solarizados é o ganho de crescimento das plantas quando comparado com culturas em solos não solarizados, devido às alterações químicas e biológicas e por não afetar populações de antagônicos e reduzir populações de patógenos (Gamliel \& Katan,1991; Lefèvre \& Souza, 1993; Souza \& Lefèvre, 1990; Stapleton \& DeVay, 1982; Stapleton \& DeVay, 1984). É evidente o potencial da solarização do solo na redução da população de fungos e bactérias patogênicos, entre eles Rhizoctonia solani (Elad et al., 1980; Lee, 1985; Osman \& Sahab, 1984; Pullman et al., 1981), Pythium spp. (Pullman et al., 1981), Verticillium dahliae (Davis \& Sorensen, 1986; Pullman et al., 1981) e Thielaviopsis basicola (Pullman et al., 1981).

Sinigaglia et al. (2001) comprovaram a eficiência da solarização no controle de Sclerotinia minor, Rhizoctonia solani e plantas daninhas em cultura comercial de alface. Apenas nos tratamentos que foram solarizados houve efetiva redução da severidade das duas doenças, destacando-se a associação de solarização com o fungicida pencycuron para queima da saia e de solarização com procimidone para murcha de esclerotinia. A solarização também afetou drasticamente a emergência das plantas daninhas avaliadas e antecipou a colheita das plantas de alface em onze dias.

Porém, existem limitações ao emprego dessa técnica, pois requer que o solo permaneça livre de culturas durante um período de até dois meses, além de ser viável somente para regiões onde ocorram altas radiações solares. Acarreta ainda o aumento dos teores de manganês no solo, além de eliminar grande quantidade de microorganismos potencialmente antagônicos (Souza, 1994). Também existe a 
dificuldade de manuseio e o alto custo para retirada, posterior utilização ou a reciclagem do plástico (Katan, 1981).

O efeito da solarização pode ser potencializado com a incorporação de matéria orgânica antes da cobertura do solo com o filme plástico (Gamliel et al., 2000; Gamliel \& Stapleton, 1993; Schoenmaker, 2001; Souza, 2001). A combinação de altas temperaturas e umidade acelera o processo de fermentação, resultando em condições de anaerobiose. De acordo com Blok et al. (2000) a sobrevivência de muitos fitopatógenos é severamente afetada sob condições anaeróbicas do solo. $\mathrm{O}$ exato mecanismo de ação ainda não foi elucidado, mas a ausência de oxigênio, o acúmulo de substâncias tóxicas resultantes da decomposição anaeróbica da matéria orgânica e o controle biológico exercido por microrganismos anaeróbicos são fatores cruciais.

Excrementos de animais são freqüentemente usados na agricultura como fertilizantes orgânicos. A cama de frango é uma forma de esterco de galinha muito utilizada pelos agricultores brasileiros. Contém significativas quantidades de N, P, K, $\mathrm{Ca}, \mathrm{Mg}$ e micronutrientes. $\mathrm{O}$ esterco de frango contém alta porcentagem de nitrogênio na forma de ácido úrico que é rapidamente convertido em nitrogênio amoniacal durante a sua decomposição. A amônia gerada é tóxica a microrganismos e nematóides fitopatogênicos (Gamliel et al., 2000; Riegel \& Noe, 2000). Palhas ou cascas de vegetais, constituintes muito comuns da cama de frango, servem como fonte de carbono para a atividade microbiana. Schoenmaker (2001) constatou efetivo controle de Pythium spp. em pepino e crisântemo em solo incorporado com cama de frango e solarizado. De acordo com a autora, a adição da cama de frango ao solo induziu supressividade ao patógeno, proporcionou maior elevação da temperatura do solo durante a solarização, maior condutividade elétrica, maior atividade microbiana (medida através da hidrólise de diacetato de fluoresceina e desprendimento de $\left.\mathrm{CO}_{2}\right)$ e diminuiu a resistência à penetração no solo.

A torta de mamona (Ricinus communis L.) é o mais importante subproduto da indústria de óleo de mamona e seu principal emprego é como fertilizante orgânico. Possui notável capacidade de melhoria das características físicas, químicas e biológicas do solo (Beltrão, 2003). Souza (2001) estudou o efeito da solarização do solo 
incorporado com $0,8 \mathrm{Kg} / \mathrm{m}^{2}$ de torta de mamona no controle de Fusarium oxysporum (Schlecht.) f. sp. lycopersici (Sacc.) Snyder and Hansen raça 2 e Sclerotium rolfsii Sacc. As estruturas de resistência de S. rolfsii foram completamente eliminadas com o tratamento, porém, o mesmo não aconteceu com F. oxysporum f. sp. lycopersici. Este fungo foi insensível inclusive às drásticas condições de anaerobiose e ao alto teor de monóxido de carbono, gás tóxico a maioria dos seres vivos, registrados durante a primeira semana de solarização. 


\section{MATERIAL E MÉTODOS}

\subsection{Local}

O presente trabalho foi desenvolvido nos laboratórios do Departamento de Entomologia, Fitopatologia e Zoologia Agrícola (setor de Fitopatologia) e no campo experimental do Departamento de Produção Vegetal da ESALQ / USP, em Piracicaba SP, situado a uma altitude de $546 \mathrm{~m}$, latitude sul de $22^{\circ} 42^{\prime} 30^{\prime}$ e longitude oeste de $47^{\circ} 38^{\prime} 00^{\prime \prime}$.

\subsection{Obtenção, identificação e conservação dos isolados de Thielaviopsis basicola}

Os isolados de T. basicola foram obtidos a partir de plantas de alface, chicória (Cichorium intybus L.) e rúcula (Eruca sativa L.) apresentando sintomas de podridão negra da raiz, provenientes de cultivos comerciais convencionais ou hidropônicos. Para a realização do isolamento, fragmentos radiculares de aproximadamente dois centímetros de comprimento, lavados em água de torneira corrente durante cinco minutos, foram depositados na superfície de discos de cenoura de um centímetro de espessura, desinfestados superficialmente segundo as recomendações de Lloyd \& Lockwood (1962) e acondicionados em placas de Petri ou placas Gerbox, em temperatura ambiente, numa adaptação da metodologia de Yarwood (1946). Após três ou quatro dias, estruturas típicas do fungo (conídios e clamidósporos) foram transferidas do tecido da cenoura para o meio de cultura BCA (20 g de batata, $20 \mathrm{~g}$ de cenoura, $20 \mathrm{~g}$ de ágar e $1.000 \mathrm{~mL}$ de água destilada). A identificação taxonômica dos isolados foi baseada na análise das estruturas morfológicas características do patógeno, de acordo com Barnett \& Hunter (1987) e Nag Raj \& Kendrick (1975). A conservação dos isolados obtidos foi feita através do método de Castellani (Figueiredo, 1967). 


\subsection{Efeito da temperatura sobre a patogenicidade in vitro de Thielaviopsis basicola}

\subsubsection{Patogenicidade in vitro do isolado $L_{1}$ a várias cultivares de alface}

A patogenicidade do isolado $\mathrm{L}_{1}$ de Thielaviopsis basicola foi avaliado em cultivares de alface, de três segmentos varietais: 1) do tipo americana (Lucy Brown, Invader, Mohawk, Raider, Tainá, Classic, Warrior), 2) do tipo lisa (Elisa, Regina, Luisa) e 3) do tipo crespa (Vera, Verônica, Locarno, New Red Fire). A utilização do isolado $\mathrm{L}_{1}$, se deve ao fato de que foi o primeiro isolado do patógeno obtido durante a pesquisa, e que vinha ocasionando graves problemas em cultivo comercial de alface (Tabela 2). $\mathrm{O}$ ensaio foi realizado em condições de laboratório, empregando-se metodologia semelhante à desenvolvida por Stanghellini \& Kronland (1986). Sementes das cultivares de alface foram desinfestadas superficialmente com hipoclorito de sódio (três partes de água destilada: uma parte de água sanitária - 0,625\% de cloro ativo) durante três minutos. Sete sementes de cada cultivar foram dispostas na superfície do meio de cultura ágar-água (15 g de ágar e $1.000 \mathrm{~mL}$ de água destilada), em placa de Petri Pyrex. No centro de cada placa, foi colocado um disco de micélio de cinco $\mathrm{mm}$ de diâmetro do isolado $\mathrm{L}_{1}$. Placas de Petri contendo apenas sementes de alface serviram de testemunha. O delineamento experimental utilizado foi o inteiramente ao acaso, em esquema fatorial 14 x 2, com quatorze cultivares de alface, com e sem inóculo, com quatro repetições. Cada parcela foi representada por uma placa de Petri. A incubação foi realizada durante 15 dias, com fotoperíodo de 12 horas, a $21 \pm 1{ }^{\circ} \mathrm{C}$, em câmara de crescimento, com lâmpadas fluorescentes de $40 \mathrm{~W}$, dispostas $40 \mathrm{~cm}$ acima das placas e a $30 \pm 1{ }^{\circ} \mathrm{C}$, em câmara de germinação, com lâmpadas fluorescentes de $20 \mathrm{~W}$, situadas na parede interna da porta. Após o período de incubação, procedeu-se à avaliação, medindo-se o comprimento das plântulas de cada parcela, através de uma régua graduada em centímetros. A avaliação da severidade da doença também foi feita, através de uma modificação da escala de notas proposta por O'Brien \& Davis (1994), descrita no item 3.4.1 e adaptada para as plântulas que foram cultivadas in vitro. Como todas as plântulas não inoculadas apresentaram nota 1 (ausência de sintomas), nas duas condições de temperatura, a análise estatística para nota foi realizada apenas com as plântulas 
inoculadas, para que somente as reais diferenças na reação das cultivares fossem evidenciadas.

\subsubsection{Patogenicidade in vitro dos isolados de Thielaviopsis basicola}

A patogenicidade de 14 isolados de $T$. basicola a cultivar suscetível de alface Elisa foi pesquisada em condições de laboratório, sob duas temperaturas: 21 e $27^{\circ} \mathrm{C}$. Empregou-se como delineamento experimental o inteiramente casualizado, com quatro repetições, cada uma representada por uma placa de Petri. A metodologia de condução e avaliação foi similar à descrita no item 3.3.1.

\subsection{Reação de cultivares de alface a Thielaviopsis basicola}

A reação de cultivares de alface a três isolados de $T$. basicola foi avaliada em dois experimentos, em condições de casa-de-vegetação.

\subsubsection{Reação varietal ao isolado $L_{1}$}

O primeiro ensaio foi conduzido no período de 14 de abril a 29 de maio de 2003. Mudas de alface foram produzidas em bandejas de isopor de 200 células e, após 30 dias foram transplantadas para bandejas de 128 células, preenchidas com um terço de substrato (Plantmax ${ }^{\circledR} \mathrm{HA}$ ) colonizado com o isolado $L_{1}$, na concentração de $7,5 \times 10^{5}$ conídios / g de substrato. Logo após o transplante, três $\mathrm{mL}$ de uma suspensão de $2 \times 10^{6}$ conídios / $\mathrm{mL}$ foi adicionada à região do colo de cada muda. Tanto o substrato utilizado para a produção das mudas, quanto o colonizado, foram previamente solarizados durante 72 horas em coletor solar (Ghini, 1997) (Figura 1). Empregou-se irrigação intermitente por aspersão. Vinte e um dias após o transplante, foram avaliados: o comprimento das mudas, através de uma trena graduada em centímetros; e a severidade da doença, por meio de uma modificação da escala de notas de O'Brien \& Davis (1994): 1 - ausência de sintomas, 2 - traços de necroses nas radicelas, 3 - menos de $50 \%$ das raízes necrosadas, 4 - mais de $50 \%$ e menos de $90 \%$ das raízes necrosadas e 5 - mais de $90 \%$ das raízes severamente afetadas, poucas íntegras (Figura 2). 


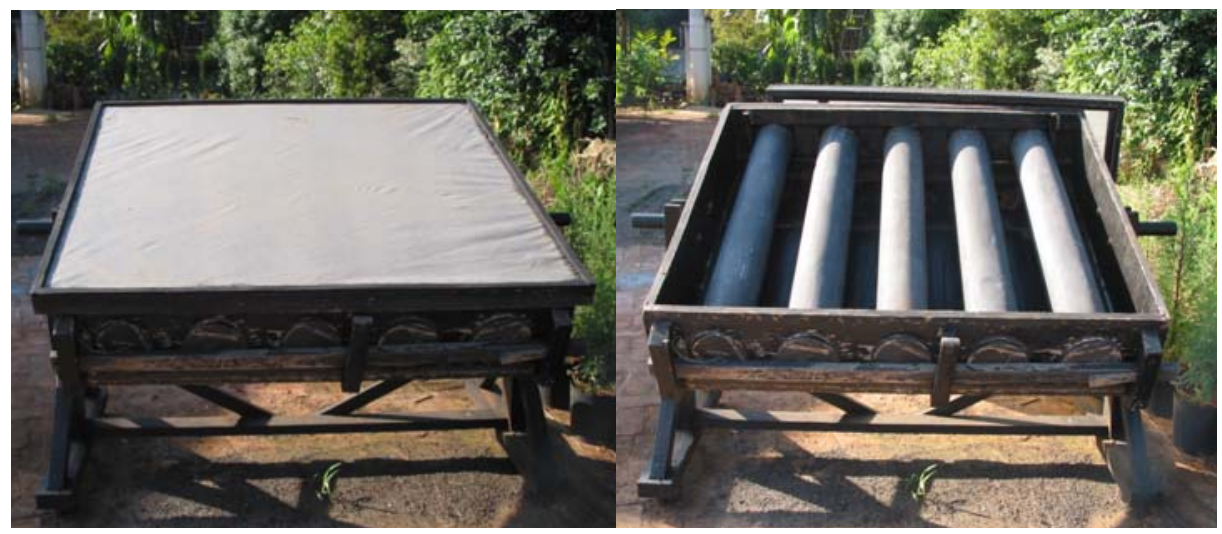

Figura 1 - Coletor solar utilizado para a solarização do substrato empregado nos ensaios em casa-de-vegetação

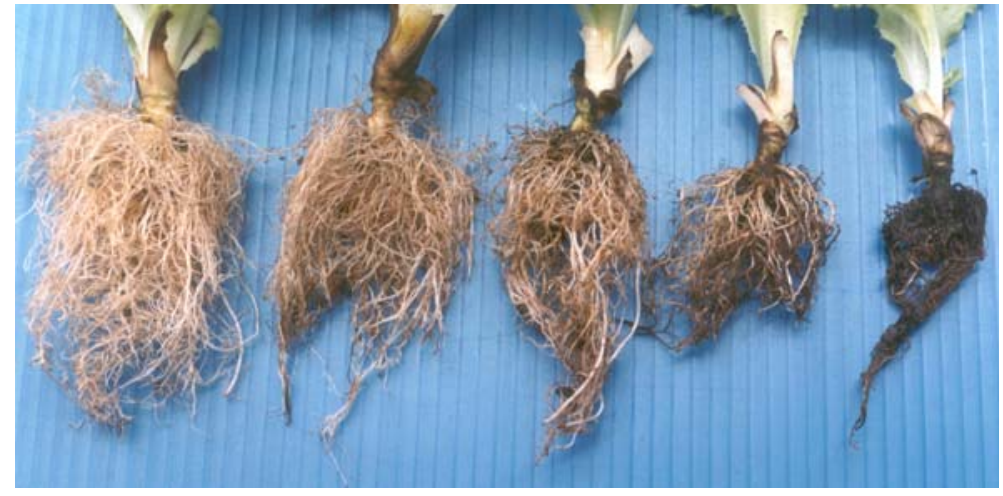

Figura 2 - Representação da escala de notas utilizada para a avaliação da severidade da podridão negra da raiz de alface. Da esquerda para a direita: nota 1 (ausência de sintomas), nota 2 (traços de necroses nas radicelas), nota 3 (menos de 50 $\%$ das raízes necrosadas), nota 4 (mais de $50 \%$ e menos de $90 \%$ das raízes necrosadas) e nota 5 (mais de $90 \%$ das raízes severamente afetadas, poucas íntegras) 
O delineamento experimental foi o inteiramente casualizado, em esquema fatorial $13 \times 2$, com treze cultivares de alface: Lucy Brown, Invader, Mohawk, Raider, Classic, Warrior, Elisa, Regina, Luisa, Vera, Verônica, Locarno e New Red Fire, com e sem inoculação, com quatro repetições. Cada parcela foi constituída por cinco mudas de alface. A análise estatística para nota foi realizada de forma similar ao item 3.3.1.

\subsubsection{Reação varietal aos isolados $\mathrm{A}_{2} \mathrm{e} \mathrm{CH}$}

O segundo experimento foi realizado no período de 5 de março a 28 de abril de 2004.

Mudas de alface foram produzidas em bandejas de isopor de 200 células, em substrato (Plantmax ${ }^{\circledR}$ HA) solarizado e, após 26 dias foram transplantadas para vasos plásticos com capacidade de $1 \mathrm{~L}$, preenchidos com substrato (Plantmax ${ }^{\circledR}$ HA) previamente solarizado e colonizado ou não com os isolados $\mathrm{A}_{2}$ e $\mathrm{CH}$. Os vasos receberam fertirrigação por meio de um sistema de gotejamento. A avaliação foi feita vinte e oito dias após o transplante das mudas, de maneira similar à descrita no item 3.4.1. A massa fresca das plantas também foi registrada, em gramas, através da pesagem das mesmas em balança digital. Como padrão referencial de resistência à doença, foram utilizadas as cultivares Raider, Warrior, Vera e New Red Fire, pois se mostraram resistentes ao isolado $L_{1}$ no teste anterior. Como referencial de suscetibilidade, foi empregada a cultivar Elisa, que é a alface do tipo lisa mais cultivada no Brasil. Incluiuse também a cultivar do tipo americana Lucy Brown, pois é a líder de mercado desse segmento varietal no nosso país há dez anos consecutivos e tem apresentado variabilidade genética tanto para características agronômicas quanto para resistência a $T$. basicola (Sala et al., 2004b). Os isolados $\mathrm{A}_{2}$ e $\mathrm{CH}$ foram utilizados em função dos resultados do ensaio de patogenicidade in vitro dos isolados de T. basicola, no qual o isolado $\mathrm{A}_{2}$ apresentou-se como o mais agressivo. $\mathrm{O}$ isolado $\mathrm{CH}$, apesar de não ter ocasionado severa podridão radicular, reduziu consistentemente o comprimento de plântulas. $\mathrm{O}$ delineamento experimental foi o inteiramente ao acaso, em esquema fatorial $6 \times 3$, com seis cultivares de alface, 3 tipos de inóculo: sem inoculação, isolado $\mathrm{A}_{2} \mathrm{e}$ isolado $\mathrm{CH}$, com cinco repetições. Cada repetição foi representada por um vaso com 
uma planta. A análise estatística para o parâmetro nota seguiu o mesmo critério do item 3.3.1.

\subsection{Efeito de fungicidas sobre o crescimento micelial e a esporulação de \\ Thielaviopsis basicola}

$\mathrm{O}$ efeito de fungicidas sobre o crescimento micelial e a esporulação de Thielaviopsis basicola foi avaliado in vitro. Foram realizados dois experimentos, nos quais os fungicidas testados foram incorporados ao meio de cultura BCA, nas concentrações de $0 ; 0,1 ; 1 ; 10$ e $100 \mathrm{mg} / \mathrm{L}$ de ingrediente ativo (i.a.). Primeiramente foi confeccionada uma suspensão estoque para cada fungicida, adicionando-se a quantidade adequada de produto em $10 \mathrm{~mL}$ de água destilada e esterilizada. A partir desta, realizaram-se diluições em série para obtenção de suspensões nas concentrações desejadas. Alíquotas de um $\mathrm{mL}$ dessas suspensões foram adicionadas a Erlenmeyers contendo meio de ágar fundente previamente autoclavado na temperatura ao redor de $45^{\circ} \mathrm{C}$. Após homogeneização do fungicida ao meio, através de agitação manual, procedeu-se sua colocação em placas de Petri esterilizadas. As testemunhas constaram de meio BCA sem fungicida (Nunes, 1992). Um disco de micélio de cinco mm de diâmetro de cada isolado foi colocado no centro de cada placa de Petri, constituindo uma parcela. A incubação foi realizada em estufa, a $25^{\circ} \mathrm{C}$, no escuro e após um período de 15 dias, procedeu-se à avaliação. No primeiro experimento foi utilizado o isolado $\mathrm{L}_{1}$ e no segundo, os isolados $\mathrm{A}_{2}$ e $\mathrm{CH}$.

$\mathrm{O}$ delineamento experimental do primeiro experimento foi o inteiramente casualizado, em esquema fatorial 9 x 5, com nove fungicidas (azoxystrobin, benomyl, carbendazim, cyproconazole, tebuconazole, tiofanato metílico, triadimenol, hexaconazole+chlorothalonil e propiconazole) e cinco concentrações $(0 ; 0,1 ; 1 ; 10$ e 100 ppm), contando com quatro repetições.

Para o segundo experimento, o delineamento experimental foi o inteiramente casualizado, em esquema fatorial 7 × 5 x 2, com sete fungicidas (benomyl, carbendazim, tiofanato metílico, cyproconazole, tebuconazole, triadimenol e 
hexaconazole+chlorothalonil), cinco concentrações $(0 ; 0,1 ; 1 ; 10$ e $100 \mathrm{ppm})$ e dois isolados $\left(\mathrm{A}_{2} \mathrm{e} \mathrm{CH}\right)$, contando com três repetições.

A avaliação do crescimento micelial foi feita com o auxílio de uma régua, registrando-se o diâmetro das colônias em dois sentidos perpendiculares entre si. O diâmetro médio das colônias em cada placa, com os produtos e respectivas doses foi comparado com o crescimento diametral médio das testemunhas, determinando-se, dessa forma, a porcentagem de inibição do crescimento micelial (PIC) (Edgington et al., 1971), expressa pela fórmula:

PIC $=\underline{\text { crescimento da testemunha }- \text { crescimento do tratamento }} \times 100$ crescimento da testemunha

A esporulação de cada tratamento foi quantificada a partir da confecção de uma suspensão de conídios, adicionando-se $10 \mathrm{~mL}$ de água destilada em cada placa de Petri, com posterior avaliação em hemacitômetro. De forma similar a PIC, foi determinada a porcentagem de inibição da esporulação (PIE), através da fórmula:

$$
\mathrm{PIE}=\underline{\text { esporulação da testemunha }- \text { esporulação do tratamento }} \times 100
$$

Apenas a redução do número de conídios foi avaliada, pois houve mínima produção de clamidósporos, mesmo nos tratamentos controles, insuficiente para adequada comparação.

Para a avaliação da eficiência dos fungicidas, baseados nos valores de PIC e $\mathrm{PIE}$, calculou-se o $\mathrm{ED}_{90}$ tanto para o crescimento micelial quanto para a esporulação. $\mathrm{O}$ $\mathrm{ED}_{90}$ consiste na concentração de ingrediente ativo necessária para a inibição de 90 \% da população do fungo.

$\mathrm{Na}$ Tabela 1 estão apresentados os fungicidas utilizados e suas principais características. Como o fungicida benomyl foi retirado do mercado, no presente trabalho, foi utilizado apenas como referencial para comparação da eficiência dos outros 
Tabela 1. Características dos fungicidas testados para o controle de Thielaviopsis basicola

\begin{tabular}{|c|c|c|c|c|c|c|}
\hline Nome técnico & $\begin{array}{l}\text { Produto } \\
\text { comercial }\end{array}$ & $\begin{array}{c}\text { Grupo } \\
\text { químico }\end{array}$ & Modo de ação & Formulação & C. $\mathbf{T}^{\mathbf{1}}$ & $\begin{array}{c}\text { Concentração de } \\
\text { i. a. }{ }^{2} \\
\end{array}$ \\
\hline azoxystrobin & $\begin{array}{l}\text { Amistar } \\
\mathrm{WG}^{\circledR}\end{array}$ & estrobilurina & $\begin{array}{l}\text { inibição da respiração } \\
\text { mitocondrial }\end{array}$ & $\begin{array}{c}\text { grânulos } \\
\text { dispersíveis em } \\
\text { água }\end{array}$ & IV & $50 \mathrm{~g} / \mathrm{Kg}$ \\
\hline benomyl & Benlate $500^{\circledR}$ & benzimidazol & $\begin{array}{l}\text { inibição da mitose - reação } \\
\text { com } \beta \text {-tubulina }\end{array}$ & pó molhável & III & $500 \mathrm{~g} / \mathrm{Kg}$ \\
\hline carbendazim & Derosal $500 \mathrm{SC}^{\circledR}$ & benzimidazol & $\begin{array}{c}\text { inibição da mitose - reação } \\
\text { com } \beta \text {-tubulina }\end{array}$ & $\begin{array}{l}\text { suspensão } \\
\text { concentrada }\end{array}$ & III & $500 \mathrm{~g} / \mathrm{L}$ \\
\hline $\begin{array}{l}\text { tiofanato } \\
\text { metílico }\end{array}$ & $\begin{array}{c}\text { Cercobin } 700 \\
\text { PM }^{\circledR}\end{array}$ & benzimidazol & $\begin{array}{l}\text { inibição da mitose - reação } \\
\text { com } \beta \text {-tubulina }\end{array}$ & pó molhável & IV & $700 \mathrm{~g} / \mathrm{Kg}$ \\
\hline cyproconazole & Alto $100 \mathrm{SC}^{\circledR}$ & triazol & $\begin{array}{l}\text { inibição da reação de } \\
\text { demetilação }\end{array}$ & $\begin{array}{l}\text { concentrado } \\
\text { solúvel }\end{array}$ & III & $100 \mathrm{~g} / \mathrm{L}$ \\
\hline propiconazole & Tilt $\mathrm{CE}^{\circledR}$ & triazol & $\begin{array}{l}\text { inibição da reação de } \\
\text { demetilação }\end{array}$ & $\begin{array}{l}\text { concentrado } \\
\text { emulsionável }\end{array}$ & III & $250 \mathrm{~g} / \mathrm{L}$ \\
\hline tebuconazole & Folicur $200 \mathrm{CE}^{\circledR}$ & triazol & $\begin{array}{l}\text { inibição da reação de } \\
\text { demetilação }\end{array}$ & $\begin{array}{l}\text { concentrado } \\
\text { emulsionável }\end{array}$ & II & $200 \mathrm{~g} / \mathrm{L}$ \\
\hline triadimenol & $\begin{array}{l}\text { Bayfidan } 250 \\
\mathrm{CE}^{\circledR}\end{array}$ & triazol & $\begin{array}{l}\text { inibição da reação de } \\
\text { demetilação }\end{array}$ & $\begin{array}{l}\text { concentrado } \\
\text { emulsionável }\end{array}$ & II & $250 \mathrm{~g} / \mathrm{L}$ \\
\hline $\begin{array}{l}\text { hexaconazole+ } \\
\text { chlorothalonil }\end{array}$ & Effect $\mathrm{SC}^{\circledR}$ & $\begin{array}{l}\text { triazol+derivado } \\
\text { de ftalonitrila }\end{array}$ & $\begin{array}{c}\text { inibição da reação de } \\
\text { demetilação / inativação de } \\
\text { enzimas }\end{array}$ & $\begin{array}{l}\text { suspensão } \\
\text { concentrada }\end{array}$ & II & $30 \mathrm{~g} / \mathrm{L}+600 \mathrm{~g} / \mathrm{L}$ \\
\hline
\end{tabular}

\footnotetext{
${ }^{1}$ Classe Toxicológica
}

${ }^{2}$ i.a. $=$ ingrediente ativo 
produtos, em função de sua bem relatada eficácia no controle de T. basicola (Gayed, 1969; Hsi \& Ortiz Jr., 1980; Manning et al., 1970; Saenger, 1970).

\subsection{Efeito de fungicidas no controle de Thielaviopsis basicola in vivo}

A eficiência de diversos fungicidas no controle de T. basicola foi avaliada em condições de casa-de-vegetação, no período de 23 de outubro a 18 de dezembro de 2003. Mudas de alface, cv. Elisa, foram produzidas em bandejas de isopor com 200 células, preenchidas com substrato (Plantmax ${ }^{\circledR} \mathrm{HA}$ ) solarizado. Trinta dias após a semeadura, as mudas foram transplantadas para vasos plásticos com capacidade de $1 \mathrm{~L}$, contendo substrato contaminado ou não. Os vasos receberam fertirrigação por meio de um sistema de gotejamento. O substrato colonizado foi previamente solarizado e recebeu uma suspensão de $10^{6}$ conídios do isolado $\mathrm{L}_{1} / \mathrm{g}$ de substrato. Dois dias antes do transplante das mudas, foi feita a rega dos vasos com $150 \mathrm{~mL}$ de cada suspensão de fungicida. Como os produtos testados não apresentam registro para a cultura de alface no Brasil, as dosagens utilizadas foram baseadas nas recomendações para outras culturas, principalmente tomate, nas concentrações indicadas na literatura ( $\mathrm{O}^{\prime}$ Brien \& Davis, 1994) e nos resultados de um ensaio realizado previamente (dados não apresentados).

O experimento foi instalado no delineamento experimental inteiramente ao acaso com nove tratamentos: 1 - Testemunha não inoculada sem aplicação de fungicida; 2 - Testemunha inoculada sem aplicação de fungicida; 3 - rega com benomyl (250 mg / L de i.a.); 4 - rega com carbendazim (350 mg/L de i.a.); 5 - rega com tiofanato metílico (490 mg / L de i.a.); 6 - rega com cyproconazole (15 mg / L de i.a.); 7 - rega com tebuconazole (200 mg / L de i.a.); 8 - rega com triadimenol (125 mg / L de i.a.) e 9 - rega com hexaconazole+chlorothalonil (94,5 mg / L de i.a.). Cada tratamento contou com nove repetições, cada uma sendo representada por um vaso com uma planta de alface.

A avaliação foi realizada vinte e um dias após o transplante das mudas, de modo semelhante ao item 3.4.1. 


\subsection{Efeito da solarização com e sem incorporação de matéria orgânica no controle de Thielaviopsis basicola em alface}

O experimento foi instalado no campo experimental do departamento de Produção Vegetal da ESALQ/USP, com o objetivo de avaliar a solarização do solo com e sem incorporação de cama-de-frango e de torta de mamona no controle da podridão negra da raiz de alface.

O ensaio foi conduzido no delineamento experimental blocos ao acaso, em esquema fatorial $3 \times 2$, com incorporação de 10 ton / ha de cama-de frango, de 10 ton / ha de torta de mamona e sem incorporação de matéria orgânica, com e sem solarização, com três repetições. Cada parcela foi constituída de um canteiro de 1,0 $\mathrm{m}$ de largura $\mathrm{x}$ 2,8 m de comprimento. Dessa forma, o ensaio contou com os seguintes tratamentos:

1. Incorporação de cama-de-frango, solarizado (CFS)

2. Incorporação de cama-de-frango, não solarizado (CFNS)

3. Incorporação de torta de mamona, solarizado (TMS)

4. Incorporação de torta de mamona, não solarizado (TMNS)

5. Substrato sem incorporação de matéria orgânica, solarizado (SS)

6. Substrato sem incorporação de matéria orgânica, não solarizado (SNS)

Em cada parcela foram colocadas, na profundidade de $10 \mathrm{~cm}$, duas bolsas de náilon contendo $0,6 \mathrm{Kg}$ de substrato contaminado (Plantmax ${ }^{\circledR} \mathrm{HA}$ - composto por vermiculita expandida, turfa processada e enriquecida e cascas processadas e enriquecidas). Para a infestação do substrato foi adicionada uma suspensão de inóculo na concentração de $10^{6}$ conídios do isolado $\mathrm{A}_{2} / \mathrm{g}$ de substrato.

A incorporação da cama de frango (proveniente do setor de aves do Departamento de Genética da ESALQ/USP - composta por casca de arroz + esterco de frango) e da torta de mamona (Nitrobrás ${ }^{\circledR}-\operatorname{com} 4,5 \%$ de $\mathrm{N}$ total, $1,2 \%$ de $\mathrm{P}_{2} \mathrm{O}_{5}, 0,8 \%$ de $\mathrm{K}_{2} \mathrm{O}, 78 \%$ de M.O., $42 \%$ de $\mathrm{C}$ e $7 \%$ de umidade) foi feita em cada parcela, no solo, a uma profundidade de aproximadamente $15 \mathrm{~cm}$ e também no substrato do interior das bolsas, em quantidade equivalente (10 ton / ha - com base no peso fresco).

Após a colocação das bolsas de náilon preenchidas com substrato em todos os tratamentos, a área experimental foi irrigada e as parcelas a serem solarizadas foram 
cobertas com plástico transparente (polietileno de baixa densidade), de expessura de 100 $\mu \mathrm{m}$ (Figura 5 - a). A solarização foi realizada no período de 21 de outubro a 25 de novembro de 2004, ou seja, durante 35 dias.

A temperatura do solo foi registrada durante todo o período de solarização, em uma parcela de cada tratamento (Figura 3). Sensores térmicos foram enterrados na profundidade de $10 \mathrm{~cm}$, na parte central de cada parcela, próximo às bolsas de náilon. Os sensores foram conectados a um coletor de dados Datalogger 21X (Campbell Scientific) (Figura 5 - b). A temperatura do ar também foi monitorada através de um sensor térmico, conectado ao mesmo Datalogger e disposto aproximadamente a um metro de altura em relação à superfície do solo. As temperaturas foram registradas a cada meia hora. Para a apresentação dos dados, foi realizada a média das temperaturas diárias de todo o período de solarização, para cada tratamento, em intervalos de uma em uma hora (Apêndice 24).

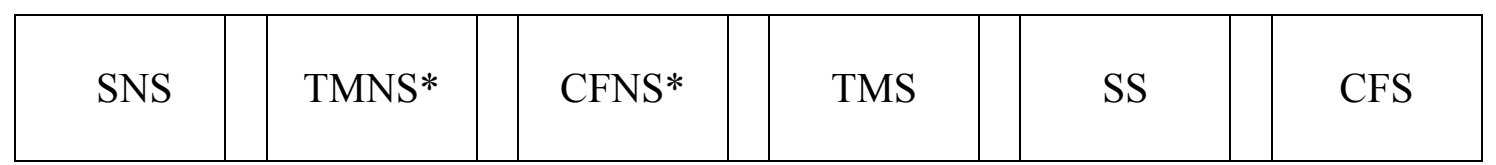

\begin{tabular}{|c|c|c|c|c|c|c|c|c|}
\hline TMS & CFS* & SS* & SNS & CFNS & TMNS \\
\hline
\end{tabular}

\begin{tabular}{|c|c|c|c|c|c|c|c|c|}
\hline SS & SNS* & & TMS* & & CFS & TMNS & CFNS \\
\hline
\end{tabular}

$$
\overline{0,5} 0 \mathrm{~m} \quad \overline{2,80 \mathrm{~m}}
$$

Figura 3 - Croquis da área experimental. As parcelas que receberam os sensores térmicos estão indicadas por asterisco $(*)$

No centro de cada parcela, entre as bolsas de náilon, foi colocada uma sonda coletora de gases (Figura 4 - a), similar à desenvolvida por Souza (2001). A sonda é 
dotada de uma mangueira de silicone, de modo que uma de suas extremidades permaneceu enterrada a $10 \mathrm{~cm}$ de profundidade. A outra extremidade ficou posicionada externamente ao solo ou ao plástico, nas parcelas solarizadas. A sua extremidade externa é vedada por um septo de borracha, que evita a saída de componentes voláteis do solo. Neste septo de borracha, conectou-se, durante cada avaliação da atmosfera do solo, a agulha do medidor de gases Texto 325-1 (Figura 4 - b, c). Este aparelho quantifica e registra (de forma impressa) instantaneamente os teores de oxigênio, dióxido de carbono e monóxido de carbono, presentes em cada parcela no momento da avaliação. Foram realizadas quatro leituras das concentrações desses gases: nos $2^{\circ}, 16^{\circ}, 23^{\circ}$ e $30^{\circ}$ dias após a cobertura do solo com o filme plástico, sempre por volta das 11:00 horas.

Após a retirada do plástico, no dia 25 de novembro de 2004, as bolsas de náilon foram desenterradas. O substrato de uma das bolsas de cada parcela que teve a temperatura do solo monitorada, foi enviado para a realização de análise química. As análises químicas dos substratos foram feitas pelo Departamento de Solos e Nutrição de plantas da ESALQ/USP. Apenas o teor de nitrogênio total foi analisado pelo Laboratório Agrotécnico Piracicaba S/C Ltda.

Os substratos contidos nas demais bolsas de náilon foram acondicionados em vasos plásticos com capacidade de $1 \mathrm{~L}$. Para estes vasos, foram transplantadas mudas de alface, cv. Elisa, com 30 dias de idade (1 muda / vaso). Os vasos foram mantidos em casa-de-vegetação, empregando-se fertirrigação, através de um sistema de gotejamento. Depois de 26 dias do transplante das mudas, no dia 21 de dezembro de 2004, realizou-se a avaliação do experimento. Foram registrados o comprimento e a massa fresca das plantas e a severidade da doença, de modo similar ao item 3.4.2. Para cada parcela, considerou-se a média das duas plantas que foram cultivadas nos substratos provenientes das duas bolsas de náilon enterradas na área solarizada. Para as parcelas que tiveram a temperatura do solo monitorada, como o substrato de uma das bolsas foi enviado para a análise química, apenas uma planta foi considerada. 


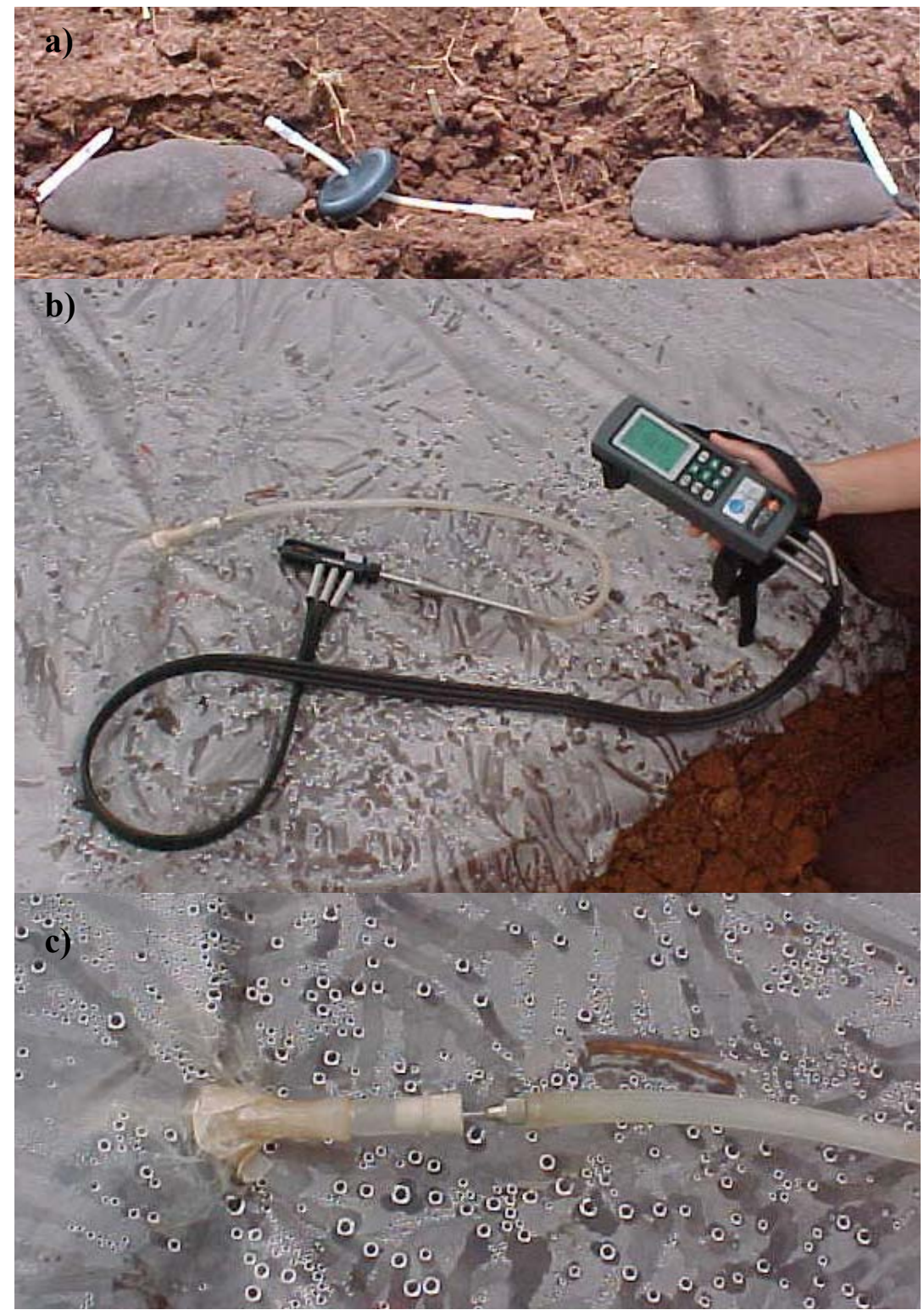

Figura 4 - Sonda coletora de gases. a) entre duas bolsas de náilon contendo substratos contaminados, antes de serem enterrados a $10 \mathrm{~cm}$ de profundidade. b) conectada ao medidor de gases Texto 325-1. c) Detalhe da conexão entre a extremidade externa da sonda e a agulha do medidor de gases 


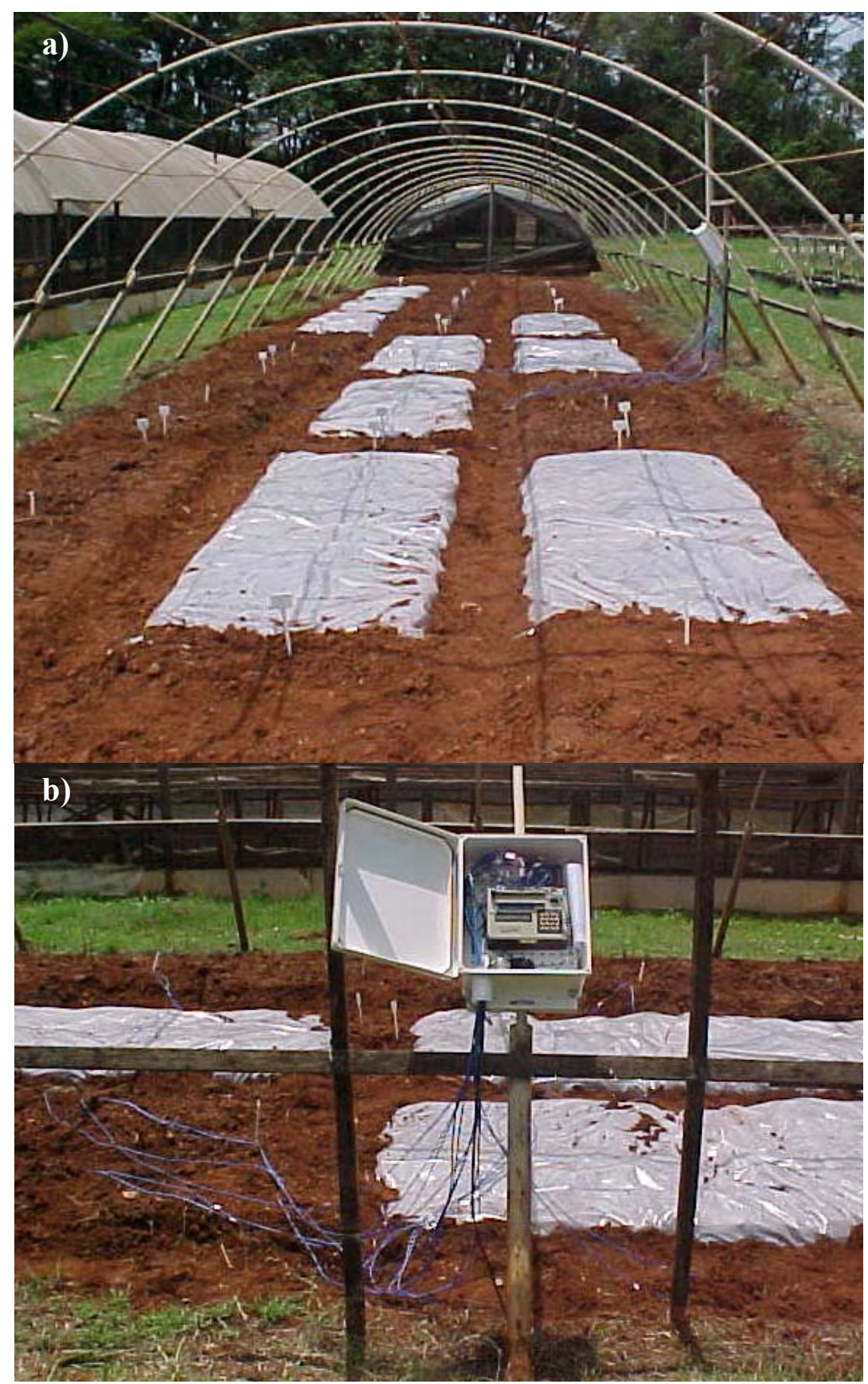

Figura 5 - Visão geral da área experimental, instalada sob a estrutura de uma estufa tipo túnel desativada (sem cobertura com plástico). a) Parcelas solarizadas e não solarizadas. b) Detalhe do Datalogger conectado aos sensores térmicos enterrados nas parcelas que tiveram a temperatura do solo avaliada durante a solarização 


\section{RESULTADOS E DISCUSSÃO}

\subsection{Obtenção dos isolados de Thielaviopsis basicola}

Quatorze isolados de Thielaviopsis basicola foram obtidos e empregados na pesquisa e suas características estão apresentadas na Tabela 2. 
Tabela 2. Isolados de Thielaviopsis basicola: data de isolamento, cultura, tipo de cultivo, estágio de crescimento da planta e local de procedência

\begin{tabular}{|c|c|c|c|c|c|}
\hline Isolado & Cultura & $\begin{array}{l}\text { Tipo de } \\
\text { cultivo }\end{array}$ & $\begin{array}{l}\text { Estágio de } \\
\text { crescimento }\end{array}$ & $\begin{array}{c}\text { Data do } \\
\text { isolamento }\end{array}$ & Procedência \\
\hline $\mathrm{L}_{1}$ & alface lisa & convencional & adulta & jan / 2002 & Paulínia (1)/SP \\
\hline $\mathrm{L}_{2}$ & alface lisa & convencional & adulta & out / 2002 & Paulínia (1)/SP \\
\hline $\mathrm{L}_{3}$ & alface lisa & convencional & adulta & out / 2002 & Paulínia (2)/SP \\
\hline $\mathrm{L}_{4}$ & alface lisa & hidroponia & intermediária & $\operatorname{mar} / 2003$ & Vinhedo/SP \\
\hline $\mathrm{L}_{5}$ & alface lisa & hidroponia & adulta & abr / 2003 & $\begin{array}{l}\text { São Miguel } \\
\text { Arcanjo/SP }\end{array}$ \\
\hline $\mathrm{A}_{1}$ & $\begin{array}{c}\text { alface } \\
\text { americana }\end{array}$ & convencional & adulta & out / 2002 & Paulínia (2)/SP \\
\hline $\mathrm{A}_{2}$ & $\begin{array}{c}\text { alface } \\
\text { americana }\end{array}$ & convencional & muda/35 dias & set / 2002 & Tietê/SP \\
\hline $\mathrm{A}_{3}$ & $\begin{array}{c}\text { alface } \\
\text { americana }\end{array}$ & convencional & muda/40 dias & set / 2002 & Tietê/SP \\
\hline $\mathrm{A}_{4}$ & $\begin{array}{c}\text { alface } \\
\text { americana }\end{array}$ & convencional & muda/25 dias & set / 2002 & Tietê/SP \\
\hline $\mathrm{A}_{5}$ & $\begin{array}{c}\text { alface } \\
\text { americana }\end{array}$ & hidroponia & adulta & mar / 2003 & Vinhedo/SP \\
\hline $\mathrm{C}_{1}$ & $\begin{array}{l}\text { alface } \\
\text { crespa }\end{array}$ & hidroponia & adulta & $\mathrm{mar} / 2003$ & Vinhedo/SP \\
\hline $\mathrm{CH}$ & chicória & convencional & adulta & jan / 2002 & Paulínia (1)/SP \\
\hline $\mathrm{R}_{1}$ & rúcula & hidroponia & intermediária & $\operatorname{mar} / 2003$ & Vinhedo/SP \\
\hline $\mathrm{R}_{2}$ & rúcula & hidroponia & intermediária & abr / 2003 & $\begin{array}{l}\text { São Miguel } \\
\text { Arcanjo/SP }\end{array}$ \\
\hline
\end{tabular}

${ }^{1}$ Propriedade A

${ }^{2}$ Propriedade B 


\subsection{Efeito da temperatura sobre a patogenicidade in vitro de Thielaviopsis basicola}

\subsubsection{Patogenicidade in vitro do isolado $L_{1}$ a várias cultivares de alface}

$\mathrm{O}$ efeito da inoculação in vitro do isolado $\mathrm{L}_{1}$ em cultivares de alface foi significativo nas duas temperaturas testadas, para os parâmetros nota e comprimento da plântula (Apêndices 1 e 2).

$\mathrm{Na}$ temperatura de $21^{\circ} \mathrm{C}$ (Tabela 3), as cultivares Elisa, Regina, Luisa (do tipo lisa), Lucy Brown, Invader, Classic e Tainá (do tipo americana) mostraram suscetibilidade. Apresentaram as maiores notas e não diferiram estatisticamente entre si. Por outro lado, a cv. New Red Fire (do tipo crespa) foi a menos sensível ao patógeno. As cultivares Verônica e Locarno (do tipo crespa) e Warrior (do tipo americana) apresentaram notas altas, acima de 4,0, enquanto Raider e Mohawk (do tipo americana) e Vera (do tipo crespa), receberam notas relativamente altas, entre 3,0 e 4,0. O isolado $\mathrm{L}_{1}$ reduziu o comprimento de todas as plântulas inoculadas em mais de $50 \%$, havendo diferença estatística entre plântulas inoculadas e não inoculadas em todas as cultivares. A maior redução do comprimento ocorreu na cv. Elisa, seguida por Vera, Regina e Luisa, consistindo em mais de 80 \%. A menor redução foi observada na cv. Warrior, com 52,84 \%. As plântulas não inoculadas exibiram desenvolvimento normal sem nenhum sintoma de apodrecimento radicular (Figura $6-\mathrm{a}, \mathrm{b}$ e d).

$\mathrm{Na}$ temperatura de $30^{\circ} \mathrm{C}$ (Tabela 4), as maiores severidades da doença foram observadas nas cultivares Regina, Elisa, Classic, Lucy Brown, Tainá, Luisa e Invader, não diferindo estatisticamente entre si. A cv. Verônica também apresentou alta severidade e não diferiu estatisticamente de Invader. Locarno foi a cultivar com a menor severidade. As demais cultivares apresentaram severidade intermediária. Nesta temperatura, o patógeno ocasionou menor redução do comprimento de plântulas que a $21^{\circ} \mathrm{C}$, reduzindo em mais de $40 \%$ o crescimento de todas as cultivares. O comprimento diferiu estatisticamente entre plântulas inoculadas e não inoculadas em todas as cultivares. A maior redução foi constatada na cv. Verônica, seguida por Regina, Tainá, Classic e Elisa, com mais de 60 \%. A menor redução, 44,15\%, ocorreu na cultivar do tipo americana Mohawk. As plântulas não inoculadas desenvolveram-se normalmente e 
Tabela 3. Patogenicidade in vitro de Thielaviopsis basicola (isolado $\mathrm{L}_{1}$ ) a cultivares de alface à $21^{\circ} \mathrm{C}$. Piracicaba, 2003

\begin{tabular}{|c|c|c|c|c|}
\hline \multirow{3}{*}{$\frac{\text { Cultivar }}{\text { Elisa }}$} & \multirow{3}{*}{$\begin{array}{c}\text { Nota }^{1,2} \\
\text { Inoculada } \\
5,00 \text { a }\end{array}$} & \multicolumn{2}{|c|}{ Comprimento da plântula $(\mathrm{cm})^{1,3}$} & \multirow{3}{*}{$\begin{array}{c}\begin{array}{c}\text { \% Redução } \\
\text { comprimento }\end{array} \\
86,17\end{array}$} \\
\hline & & Testemunha & Inoculada & \\
\hline & & $13,74 \mathrm{ab} A$ & 1,90 & \\
\hline Regina & $5,00 \mathrm{a}$ & hi A & 1,04 & 84,02 \\
\hline Luisa & 5,00 a & 12,32 bc A & 2,25 bc B & 81,74 \\
\hline Lucy Brown & 5,00 a & 10,37 & 2,32 bc B & 77,63 \\
\hline Invader & 5,00 a & efg A & 1,83 & 78,96 \\
\hline Classic & 4,89 a & ij A & 1,30 & 77,03 \\
\hline Tainá & 4,88 a & $\mathrm{jk} A$ & 1,80 & 64,64 \\
\hline Verônica & $4,66 \mathrm{ab}$ & gh A & 1,75 & 75,96 \\
\hline Warrior & $4,35 \mathrm{bc}$ & 4,22 & 1,99 cd B & 52,84 \\
\hline Locarno & $4,00 \quad \mathrm{c}$ & efg $\mathrm{A}$ & $2,44 \quad b$ B & 72,55 \\
\hline Raider & 3,53 & $9,75 \operatorname{def} \mathrm{A}$ & 3,87 a B & 60,31 \\
\hline Mohawk & 3,47 & 8,44 fg A & $2,60 \quad b B$ & 69,19 \\
\hline Vera & 3,46 & 15,52 a $\mathrm{A}$ & 2,46 b B & 84,15 \\
\hline New Red Fire & 3,00 & $10,87 \mathrm{~cd} A$ & $2,58 \quad b$ B & 76,26 \\
\hline $\mathrm{CV}(\%)$ & 1,83 & 9,97 & & \\
\hline
\end{tabular}

Média de 4 repetições, cada uma representada por uma placa de Petri com 7 plântulas. Médias seguidas por letras distintas minúsculas na coluna e maiúsculas na linha diferem entre si pelo teste de Tukey a 0,05 .

${ }^{2}$ Dados originais. Para efeito de análise estatística, os dados foram transformados em raiz quadrada de $\mathrm{x}+0,5$.

${ }^{3}$ Dados originais. Para efeito de análise estatística, os dados foram transformados em logaritmo de $\mathrm{x}$ na base 10 . 
Tabela 4. Patogenicidade in vitro de Thielaviopsis basicola (isolado $\mathrm{L}_{1}$ ) a cultivares de alface à $30^{\circ} \mathrm{C}$. Piracicaba, 2003

\begin{tabular}{|c|c|c|c|c|}
\hline \multirow{3}{*}{$\frac{\text { Cultivar }}{\text { Regina }}$} & \multirow{2}{*}{$\begin{array}{c}\text { Nota }^{1,2} \\
\text { Inoculada }\end{array}$} & \multicolumn{2}{|c|}{$\begin{array}{l}\text { Comprimento da plântula } \\
\qquad(\mathrm{cm})^{1,3}\end{array}$} & \multirow{3}{*}{$\begin{array}{c}\begin{array}{c}\text { \% Redução } \\
\text { comprimento }\end{array} \\
67,40\end{array}$} \\
\hline & & Testemunha & Inoculada & \\
\hline & $5,00 \mathrm{a}$ & 5,00 bc A & 1,63 & \\
\hline Elisa & 4,96 a & 5,81 ab A & $2,13 \quad \mathrm{~cd} \mathrm{~B}$ & 63,34 \\
\hline Classic & 4,96 a & 5,37 bc A & 1,94 de B & 63,87 \\
\hline Lucy Brown & $4,85 \mathrm{a}$ & $6,39 \mathrm{ab} \mathrm{A}$ & 2,89 b B & 54,77 \\
\hline Tainá & 4,82 a & 5,59 b A & 1,92 de B & 65,65 \\
\hline Luisa & 4,71 a & 6,21 ab A & $2,89 \quad \mathrm{~b} \mathrm{~B}$ & 53,46 \\
\hline Invader & $4,46 a b$ & $6,53 \mathrm{ab} A$ & $2,63 \quad \mathrm{~b} \mathrm{~B}$ & 59,72 \\
\hline Verônica & $3,96 \mathrm{bc}$ & 6,82 a $A$ & $2,06 \quad \mathrm{~d} B$ & 69,79 \\
\hline Raider & $3,39 \mathrm{~cd}$ & 5,35 bc A & 2,86 b B & 46,54 \\
\hline Warrior & $3,03 \quad \mathrm{~d}$ & 4,50 с A & $2,11 \quad \mathrm{~cd} \mathrm{~B}$ & 53,11 \\
\hline Vera & 2,21 & 6,74 a A & 3,67 a B & 45,55 \\
\hline Mohawk & 2,18 & 5,39 bc A & 3,01 ab B & 44,15 \\
\hline New Red Fire & 2,03 & 6,08 ab A & $2,83 \mathrm{~b} \mathrm{~B}$ & 53,45 \\
\hline Locarno & 1,65 & 6,31 ab A & $2,53 \mathrm{bc} \mathrm{B}$ & 59,90 \\
\hline CV (\%) & 3,06 & $9,8 \mathrm{~s}$ & & \\
\hline
\end{tabular}

Média de 4 repetições, cada uma representada por uma placa de Petri com 7 plântulas. Médias seguidas por letras distintas minúsculas na coluna e maiúsculas na linha diferem entre si pelo teste de Tukey a 0,05 .

${ }^{2}$ Dados originais. Para efeito de análise estatística, os dados foram transformados em raiz quadrada de $\mathrm{x}+0,5$.

${ }^{3}$ Dados originais. Para efeito de análise estatística, os dados foram transformados em logaritmo de $\mathrm{x}$ na base 10 .

sem indícios de necrose nas raízes, porém, o desenvolvimento foi menor que a $21^{\circ} \mathrm{C}$ (Figura 6 - c).

A reação das cultivares de alface ao isolado $\mathrm{L}_{1}$ de Thielaviopsis basicola foi semelhante a 21 e a $30^{\circ} \mathrm{C}$ (Tabelas 3 e 4). As maiores severidades da doença foram 
exibidas pelas mesmas cultivares nas duas condições de temperatura, exceto Verônica a $30^{\circ} \mathrm{C}$. A cv. New Red Fire, apesar de ter apresentado baixa severidade da doença, sofreu alta redução do comprimento de plântulas inoculadas, a 21 e a $30^{\circ} \mathrm{C}$. A cv. Verônica, que exibiu a segunda estatisticamente maior nota e a maior redução do comprimento a $30^{\circ} \mathrm{C}$, também apresentou a segunda estatisticamente maior nota e alta redução do comprimento das plântulas inoculadas a $21^{\circ} \mathrm{C}$. Nas duas temperaturas, as cultivares que apresentaram as menores notas, New Red Fire a $21^{\circ} \mathrm{C}$ e Locarno a $30^{\circ} \mathrm{C}$, exibiram grande diminuição no crescimento.

De modo geral, o isolado $\mathrm{L}_{1}$ foi mais agressivo a $21^{\circ} \mathrm{C}$ que a $30^{\circ} \mathrm{C}$, ocasionando maiores severidades da doença (Apêndices 3 e 4) e maior subdesenvolvimento de plântulas em todas as cultivares, na menor temperatura (Tabelas 3 e 4). Esses resultados estão de acordo com várias pesquisas realizadas com o patógeno, as quais apontam que a severidade da doença é reduzida em temperaturas acima de $28^{\circ} \mathrm{C}$ (Mauk \& Hine, 1988; Papavizas \& Lewis, 1977; Rothrock, 1992). Prinsloo et al. (1991), ao estudarem a influência de diversos fungos no desenvolvimento da podridão negra da raiz de chicória, demonstraram que T. basicola é o principal agente causal e, que o mesmo causa severa necrose em raízes sem ferimentos tanto a $25^{\circ} \mathrm{C}$ quanto à $30^{\circ} \mathrm{C}$. Entretanto, quando foram consideradas raízes apresentando ferimentos, o patógeno foi mais agressivo a $25^{\circ} \mathrm{C}$ do que a $30^{\circ} \mathrm{C}$.

O objetivo inicial da avaliação da patogenicidade in vitro de T. basicola sob duas condições de temperatura, foi o de evidenciar o efeito da temperatura na expressão da doença e pesquisar a viabilidade da realização da seleção de cultivares de alface resistentes ao patógeno em condições controladas. Porém, não houve correlação dos resultados destes testes in vitro (a 21 e $30^{\circ} \mathrm{C}$ ) com aqueles obtidos nos testes in vivo (item 4.3) e com o que é geralmente observado nos campos de produção de alface. Com relação ao efeito da temperatura na expressão da doença, observa-se, em condições naturais, pelo menos nas maiores regiões produtoras de alface do Estado de São Paulo, que a doença é mais severa no período do verão, quando ocorrem temperaturas altas (maiores que $21^{\circ} \mathrm{C}$ ). É provável que haja diferença na faixa de temperatura ótima para o desenvolvimento da doença entre diversos patossistemas e / ou isolados fúngicos, pois, 


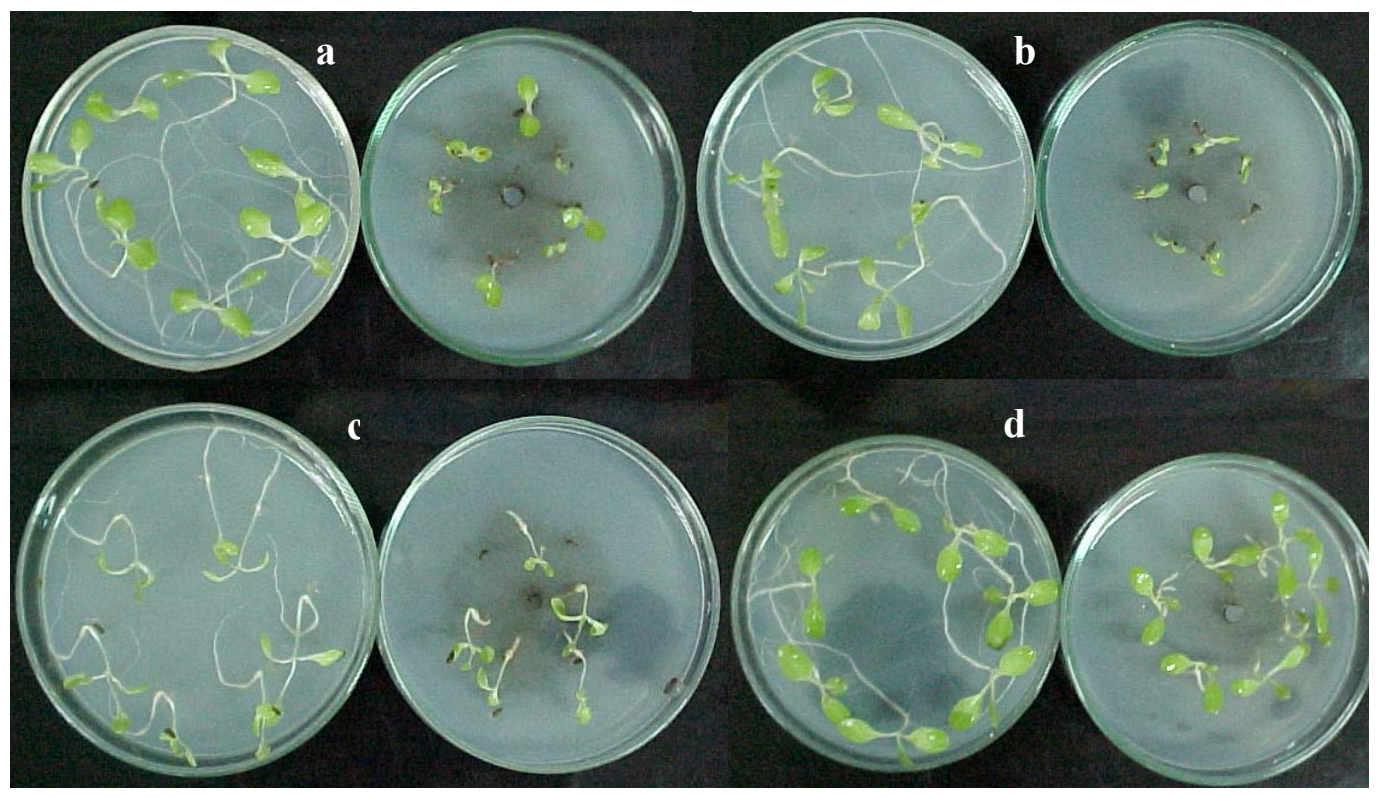

Figura 6 - Efeito da temperatura sobre a patogenicidade in vitro do isolado $\mathrm{L}_{1}$ de Thielaviopsis basicola a alface. À esquerda: plântulas não inoculadas e à direita: plântulas inoculadas. a) $\mathrm{Cv}$. Elisa a $21^{\circ} \mathrm{C}$, b) $\mathrm{Cv}$. Regina a $21^{\circ} \mathrm{C}$, c) $\mathrm{Cv}$. Elisa a $30^{\circ} \mathrm{C}$ e d) $\mathrm{Cv}$. New Red Fire a $21^{\circ} \mathrm{C}$

Mauk \& Hine (1988) encontraram que a podridão negra da raiz de algodão foi mais severa a $20^{\circ} \mathrm{C}$ que a $28^{\circ} \mathrm{C}$, enquanto Lloyd \& Lockwood (1963) demonstraram que T. basicola ocasionou sintomas mais drásticos em raízes de ervilha (Pisum sativum L.) na temperatura do solo de $28^{\circ} \mathrm{C}$, quando comparada a $16,20,24$ ou $32^{\circ} \mathrm{C}$. A reação varietal ao patógeno observada em casa-de-vegetação (item 4.3) não correspondeu à encontrada no teste in vitro. Esse fato se deve, provavelmente, à drástica metodologia de inoculação in vitro e ao estágio extremamente juvenil da planta, inábil para a expressão da resistência ao patógeno.

\subsubsection{Patogenicidade in vitro dos isolados de Thielaviopsis basicola}

Segundo a análise estatística dos resultados, houve influência significativa da inoculação de diversos isolados de T. basicola em plântulas de alface, cv. Elisa, nas duas 
temperaturas avaliadas (Apêndices 5 e 6). Todos os isolados avaliados foram capazes de incitar algum tipo de necrose radicular e promover a redução do comprimento das plântulas, diferindo estatisticamente da testemunha, tanto a $21^{\circ} \mathrm{C}$ quanto à $27^{\circ} \mathrm{C}$ (Tabela $5)$.

$\mathrm{Na}$ temperatura de $21^{\circ} \mathrm{C}$ (Tabela 5), os isolados que ocasionaram maior severidade da doença foram: $A_{2}, A_{3}, A_{5}, L_{1}$ e $L_{3}$. As menores severidades foram exibidas pelas plântulas inoculadas com os isolados $\mathrm{CH}$ e $\mathrm{R}_{1}$. Apesar do isolado $\mathrm{CH}$ ter incitado a menor severidade da doença, ocasionou a maior redução do comprimento das plântulas, seguido pelos isolados $\mathrm{A}_{2}$ e $\mathrm{C}_{1}$, que também promoveram uma redução no comprimento de mais de $80 \%$. $\mathrm{O}$ isolado $\mathrm{R}_{2}$ foi o que causou a menor restrição no crescimento das plântulas. Nessa temperatura, todos os isolados foram capazes de restringir em mais de 55 \% o comprimento das plântulas inoculadas.

$\mathrm{Na}$ temperatura de $27^{\circ} \mathrm{C}$ (Tabela 5), as maiores severidades foram incitadas pelos isolados $A_{2}, A_{3}, A_{5}, L_{3}, L_{4}, L_{5}, C_{1}$ e $R_{1}$. Os isolados $L_{2}$ e $A_{4}$ ocasionaram menor podridão radicular e $\mathrm{L}_{1}, \mathrm{~A}_{1}, \mathrm{R}_{2}$ e $\mathrm{CH}$ foram responsáveis por severidades intermediárias. Quanto ao comprimento de plântulas, a maior redução foi causada por $\mathrm{A}_{2}$, seguida por $\mathrm{C}_{1}$ e $\mathrm{R}_{1}$, com mais de $80 \%$ de restrição do crescimento. $\mathrm{O}$ isolado $\mathrm{L}_{5}$ ocasionou a menor diminuição do comprimento, entretanto, todos os isolados restringiram mais de $65 \%$ do comprimento de plântulas nessa temperatura. Apesar do isolado $\mathrm{L}_{2}$ ter promovido a menor nota, reduziu $68,15 \%$ do comprimento.

Dentre os isolados avaliados, o $\mathrm{A}_{2}$ pode ser considerado o mais agressivo. Causou alta severidade da doença nas duas temperaturas testadas, a segunda maior redução do comprimento a $21^{\circ} \mathrm{C}$ e a maior redução a $27^{\circ} \mathrm{C}$. O isolado $\mathrm{C}_{1}$ ocasionou altas severidades da doença e reduziu em mais de $80 \%$ o comprimento de plântulas nas duas condições de temperatura. A maior temperatura favoreceu os isolados $\mathrm{R}_{2}$ e $\mathrm{L}_{5}$, que causaram maior podridão radicular e subdesenvolvimento de plântulas a $27^{\circ} \mathrm{C}$. Quanto ao isolado $\mathrm{CH}$, apesar de ter incitado maior severidade da doença a $27^{\circ} \mathrm{C}$ do que a $21^{\circ} \mathrm{C}$, causou menor redução do comprimento de plântulas na maior temperatura. $\mathrm{R}_{1}$ ocasionou muito mais necrose radicular a $27^{\circ} \mathrm{C}$ que a $21^{\circ} \mathrm{C}$, mas promoveu grande subdesenvolvimento de plântulas nas duas temperaturas. A $27^{\circ} \mathrm{C}, \mathrm{L}_{5}$ ocasionou a maior 
Tabela 5. Patogenicidade in vitro de quatorze isolados de Thielaviopsis basicola a plântulas de alface, cv. Elisa, a 21 e $27^{\circ} \mathrm{C}$. Piracicaba, 2003

\begin{tabular}{|c|c|c|c|c|c|c|c|}
\hline \multirow{3}{*}{$\frac{\text { Isolado }}{\mathrm{A}_{2}}$} & \multicolumn{2}{|c|}{ Nota $^{1,2}$} & \multicolumn{3}{|c|}{$\begin{array}{l}\text { Comprimento da plântula } \\
\qquad(\mathrm{cm})^{1,3}\end{array}$} & \multicolumn{2}{|c|}{$\begin{array}{l}\text { \% Redução } \\
\text { comprimento }\end{array}$} \\
\hline & $21^{\circ} \mathrm{C}$ & $27^{\circ} \mathrm{C}$ & $21^{\circ} \mathrm{C}$ & \multicolumn{2}{|c|}{$27^{\circ} \mathrm{C}$} & $21^{\circ} \mathrm{C}$ & $27^{\circ} \mathrm{C}$ \\
\hline & $5,00 \mathrm{a}$ & $4,82 \mathrm{ab}$ & 2,54 & 2,25 & g & 82,41 & 81,04 \\
\hline $\mathrm{L}_{3}$ & $4,85 \mathrm{a}$ & 5,00 a & $3,80 \quad \mathrm{de}$ & 3,00 & cdef & 73,68 & 74,73 \\
\hline $\mathrm{A}_{5}$ & $4,71 \mathrm{ab}$ & $5,00 \mathrm{a}$ & 3,32 & 2,43 & $\mathrm{fg}$ & 77,01 & 79,53 \\
\hline $\mathrm{L}_{1}$ & $4,64 \mathrm{ab}$ & $4,09 \quad \mathrm{c}$ & 3,11 & 2,69 & efg & 78,46 & 77,34 \\
\hline $\mathrm{A}_{3}$ & $4,57 \mathrm{abc}$ & $5,00 \mathrm{a}$ & 3,34 & 2,55 & efg & 76,87 & 78,52 \\
\hline $\mathrm{L}_{4}$ & $4,25 \mathrm{bc}$ & $5,00 \mathrm{a}$ & $4,63 \mathrm{~cd}$ & 2,68 & efg & 67,94 & 77,42 \\
\hline $\mathrm{C}_{1}$ & $4,00 \quad \mathrm{c}$ & 4,93 ab & 2,87 & 2,27 & g & 80,12 & 80,88 \\
\hline $\mathrm{L}_{2}$ & 3,28 & 2,00 & 3,43 & 3,78 & $\mathrm{bc}$ & 76,25 & 68,15 \\
\hline$A_{1}$ & 3,00 & $4,00 \mathrm{~cd}$ & 3,93 de & 2,71 & defg & 72,78 & 77,17 \\
\hline $\mathrm{A}_{4}$ & 2,96 & 2,28 & $4,63 \mathrm{~cd}$ & 3,53 & bcd & 67,94 & 70,26 \\
\hline $\mathrm{L}_{5}$ & 2,93 & $5,00 \mathrm{a}$ & 5,82 bc & 3,99 & $\mathrm{~b}$ & 59,69 & 66,38 \\
\hline $\mathrm{R}_{2}$ & 2,68 & 4,32 bc & $6,32 \quad b$ & 3,27 & bcde & 56,23 & 72,45 \\
\hline $\mathrm{R}_{1}$ & 2,21 & $5,00 \mathrm{a}$ & 3,52 & 2,27 & g & 75,62 & 80,88 \\
\hline $\mathrm{CH}$ & 2,07 & $3,50 \quad \mathrm{~d}$ & 2,27 & 3,29 & bcde & 84,28 & 72,28 \\
\hline Testemunha & 1,00 & 1,00 & $14,44 \mathrm{a}$ & 11,87 & $\mathrm{a}$ & --- & --- \\
\hline CV $(\%)$ & 2,65 & 2,52 & 6,83 & 9,28 & & & \\
\hline
\end{tabular}

${ }^{\mathrm{T}}$ Média de 4 repetições, cada uma representada por uma placa de Petri com 7 plântulas. Médias seguidas por letras distintas diferem entre si pelo teste de Tukey a 0,05 .

${ }^{2}$ Dados originais. Para efeito de análise estatística, os dados foram transformados em raiz quadrada de $\mathrm{x}+0,5$.

${ }^{3}$ Dados originais. Para efeito de análise estatística, os dados foram transformados em logaritmo de $\mathrm{x}$ na base 10 . 


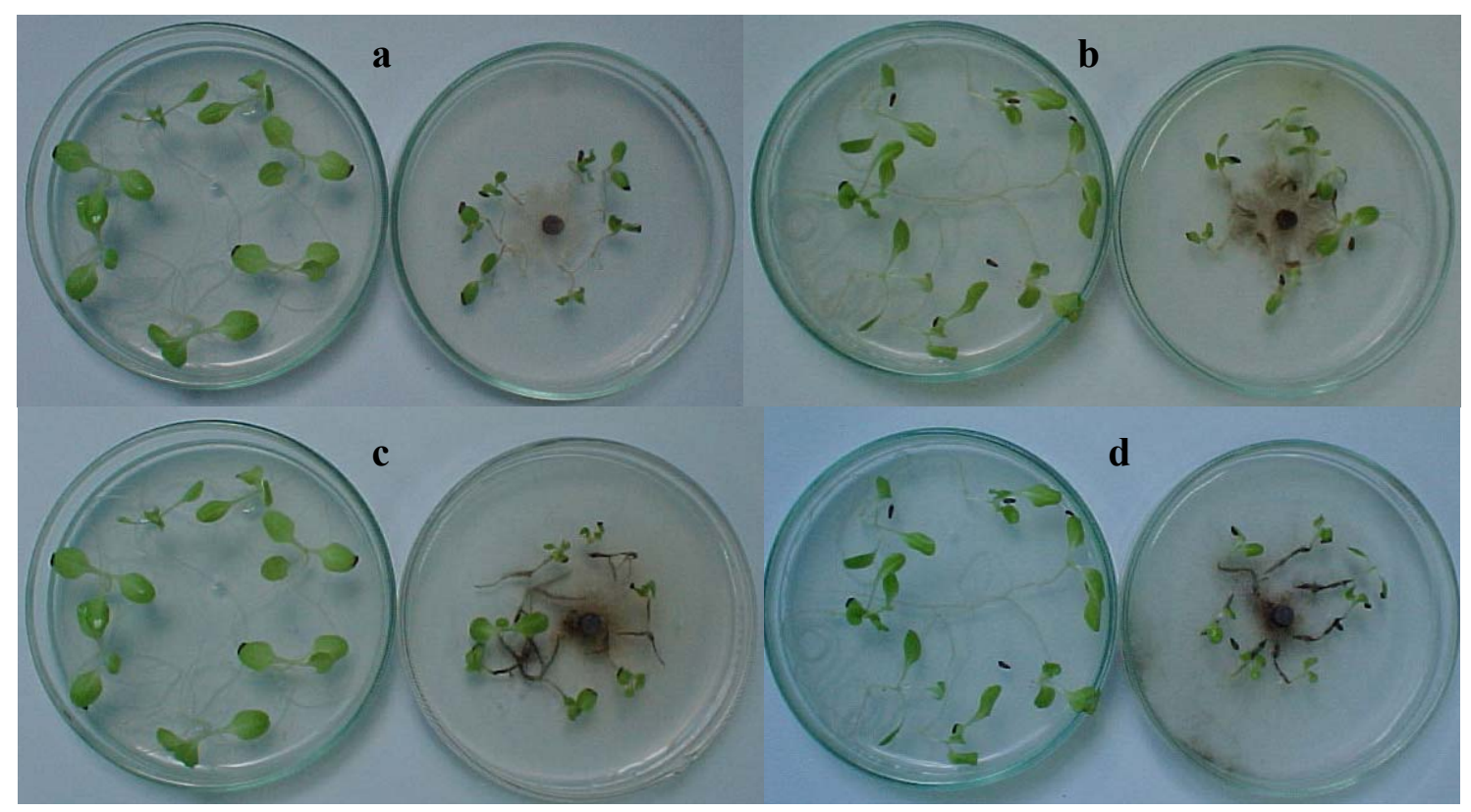

Figura 7 - Efeito da temperatura sobre a patogenicidade in vitro de dois isolados de Thielaviopsis basicola na cv. Elisa. À esquerda: plântulas não inoculadas e à direita: plântulas inoculadas. a) Isolado $\mathrm{CH}$ a $21^{\circ} \mathrm{C}$. b) Isolado $\mathrm{CH}$ a $27^{\circ} \mathrm{C}$. c) Isolado $\mathrm{A}_{2}$ a $21^{\circ} \mathrm{C}$ e d) Isolado $\mathrm{A}_{2}$ a $27^{\circ} \mathrm{C}$

severidade da doença e o menor subdesenvolvimento de plântulas, fato antagônico ao ocorrido com o isolado $\mathrm{CH}$ na temperatura de $21^{\circ} \mathrm{C}$.

A temperatura influenciou a severidade da podridão negra da raiz de alface, em placa de Petri, incitada pelos diversos isolados de T. basicola. Diversos autores relataram a maior agressividade de $T$. basicola sob condições de temperatura adversas ao desenvolvimento do hospedeiro (Bateman \& Dimock, 1959; Bhatti \& Kraft, 1992a; Lloyd \& Lockwood, 1963). Essas observações são confirmadas pelos resultados apresentados, pois, de acordo com Marcos Filho et al. (1985), a temperatura de $21^{\circ} \mathrm{C}$ é considerada ótima para a germinação das sementes e o desenvolvimento de plântulas de alface. De modo geral, os isolados avaliados foram mais agressivos a $27^{\circ} \mathrm{C}$ do que a $21^{\circ} \mathrm{C}$, exceto $\mathrm{L}_{1}$ e $\mathrm{L}_{2}$ (Tabela 5, Figura 7, Apêndices 7 e 8). Todavia, é de grande importância que mais estudos sejam realizados para determinar a faixa de temperatura 
ótima para o desenvolvimento da podridão negra da raiz de alface em condições brasileiras.

Os isolados de T. basicola apresentaram agressividade diferenciada para a cultivar de alface Elisa. A variação na virulência e na habilidade de infectar diferentes hospedeiros, exibida pelos isolados de T. basicola, foi relatada por vários pesquisadores (Lloyd \& Lockwood, 1963; Stover, 1951; Tabachnick et al., 1979). O’Brien \& Davis (1994) estudaram a capacidade de dois isolados de T. basicola obtidos de alface em infectar diversos hospedeiros. De acordo com os autores, os isolados ocasionaram severa podridão radicular em duas cultivares de alface (Classic e Great Lakes) e em feijão. Melancia (cv. Crimson Sweet), pepino (cv. Crystal Apple) e melão (Cucumis melo L. cv. Laguna) foram menos severamente afetados e pimenta (Capsicum frutescens L. - cv. Northern Bell), tomate (Lycopersicon esculentum Miller - cv. Floradade), berinjela (Solanum melongena L. - cv. N. Y. Purple), agrião (Rorippa nasturtium-aquaticum (L.) Hayek), aipo (Apium graveolens L. - cv. Tendercrisp), salsa (Petroselinum crispum (Mill.) Nym.), rabanete (Raphanus sativus L. - cv. French Breakfast) e algodão (cv. Siokra-1-4) não foram afetados pelos isolados fúngicos.

Na presente pesquisa, os isolados obtidos de outras espécies de hospedeiros $\left(R_{1}\right.$, $\mathrm{R}_{2}$ e $\mathrm{CH}$ ), apesar de terem ocasionado as menores severidades da doença a $21^{\circ} \mathrm{C}$, foram patogênicos a alface nas duas condições de temperatura e bastante agressivos a $27^{\circ} \mathrm{C}$ (Tabela 5, Figura 7, Apêndices 7 e 8).

\subsection{Reação de cultivares de alface a Thielaviopsis basicola}

\subsubsection{Reação varietal ao isolado $L_{1}$}

As cultivares de alface avaliadas apresentaram reação diferenciada à inoculação com o isolado $\mathrm{L}_{1}$ de Thielaviopsis basicola (Apêndices 9 e 10, Tabela 6).

De acordo com a Tabela 6 e Apêndices 11 e 12, as cultivares Luisa, Regina, Elisa, Invader e Classic foram suscetíveis ao patógeno, não diferindo estatisticamente entre si. New Red Fire, Mohawk, Raider, Vera, Warrior e Locarno mostraram resistência ao isolado $\mathrm{L}_{1}$, destacando-se a New Red Fire que não exibiu nenhum sintoma de necrose radicular. As cultivares Lucy Brown e Verônica apresentaram severidade intermediária 
da doença, não diferindo estatisticamente da Locarno, a qual também não foi estatisticamente diferente das variedades que se mostraram resistentes ao fungo.

Tabela 6. Reação de cultivares de alface a Thielaviopsis basicola (isolado $\mathrm{L}_{1}$ ) em casade-vegetação. Piracicaba, 2003

\begin{tabular}{cccccccc}
\hline & \multicolumn{2}{c}{$\begin{array}{c}\text { Nota } \\
\text { Cultivar }\end{array}$} & \multicolumn{2}{c}{ Comprimento da muda (cm) } & \% \\
Inoculada & \multicolumn{2}{c}{ Testemunha } & Inoculada & comprimento \\
\hline Luisa & 4,20 & a & 14,92 & abc A & 13,12 & cd A & 12,06 \\
Regina & 4,10 & a & 14,20 & bc A & 10,50 & e B & 26,06 \\
Elisa & 3,25 & ab & 14,37 & bc A & 12,32 & d B & 14,26 \\
Invader & 3,20 & ab & 15,62 & ab A & 12,82 & d B & 17,92 \\
Classic & 3,12 & ab & 14,97 & abc A & 14,92 & abc A & 0,33 \\
Lucy Brown & 2,65 & bc & 15,70 & ab A & 13,65 & bcd B & 13,06 \\
Verônica & 2,35 & bc & 15,87 & ab A & 13,90 & bcd B & 12,41 \\
Locarno & 1,65 & cd & 13,20 & c A & 12,42 & d A & 5,91 \\
Warrior & 1,25 & d & 16,37 & a A & 16,25 & a A & 0,73 \\
Vera & 1,20 & d & 15,00 & abc A & 15,00 & ab A & 0,00 \\
Raider & 1,15 & d & 14,50 & bc A & 15,27 & ab A & $-5,31$ \\
Mohawk & 1,10 & d & 14,17 & bc A & 15,22 & ab A & $-7,41$ \\
New Red Fire & 1,00 & d & 15,87 & ab A & 16,32 & a A & $-2,83$ \\
CV (\%) & 8,04 & & & 8,89 & & \\
\hline
\end{tabular}

${ }^{1}$ Média de 4 repetições, cada uma representada por 5 mudas de alface. Médias seguidas por letras distintas minúsculas na coluna e maiúsculas na linha diferem entre si pelo teste de Tukey a 0,05 .

${ }^{2}$ Dados originais. Para efeito de análise estatística, os dados foram transformados em raiz quadrada de $\mathrm{x}+0,5$. 


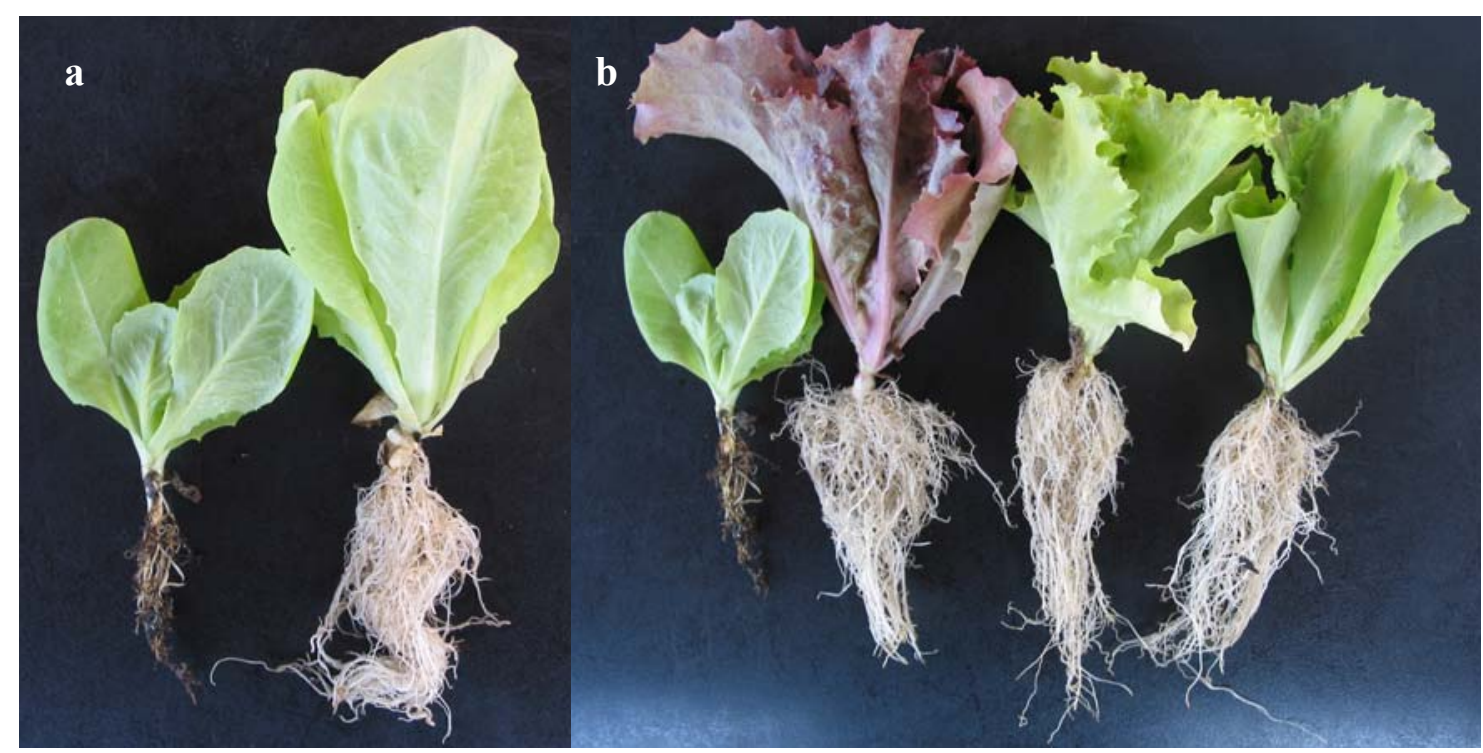

Figura 8 - Reação de cultivares de alface ao isolado $\mathrm{L}_{1}$ de Thielaviopsis basicola. a) $\mathrm{Cv}$. Elisa, à esquerda: muda inoculada e à direita: testemunha. b) Mudas inoculadas, da esquerda para a direita: cvs. Elisa, New Red Fire, Vera e Mohawk

Com respeito à porcentagem de redução do comprimento das mudas, a maior restrição ocorreu na cv. Regina, seguida por Invader, Elisa, Lucy Brown, Verônica e Luisa. Nas demais cultivares, houve pequena diminuição do crescimento. As mudas inoculadas de Raider, Mohawk e New Red Fire apresentaram maior crescimento que as não inoculadas (Tabela 6).

De maneira geral, as cultivares de alface do tipo lisa foram suscetíveis ao patógeno, enquanto as do tipo crespa foram resistentes, exceto Verônica. Entre as cultivares do tipo americana, Invader, Classic e Lucy Brown foram suscetíveis, enquanto Warrior, Raider e Mohawk foram resistentes ao fungo. Essa variação na reação de cultivares de alface (ilustrada na Figura 8) à podridão negra da raiz também foi encontrada por O’Brien \& Davis (1994). Esses pesquisadores constataram que entre diversas cultivares de alface comercializadas na Austrália, Classic, Yatesdale e Buffalo foram altamente suscetíveis, Monaro e Kirralee foram altamente resistentes e 
Nambucco, Centenary, Target e Galaxy apresentaram reação intermediária a T. basicola, em condições de casa-de-vegetação.

\subsubsection{Reação varietal aos isolados $A_{2}$ e $C H$}

Houve efeito da inoculação com os isolados $\mathrm{A}_{2}$ e $\mathrm{CH}$ de Thielaviopsis basicola sobre as cultivares de alface avaliadas. A interação entre cultivares e tipo de inóculo foi significativa (Apêndices 13 e 14).

As cultivares Raider, Warrior, New Red Fire e Vera, que foram resistentes ao isolado $\mathrm{L}_{1}$, também mostraram resistência aos isolados $\mathrm{A}_{2}$ e $\mathrm{CH}$, apresentando baixíssimas severidades da doença. Inclusive a inoculação de Vera com o isolado $\mathrm{CH}$ não resultou no aparecimento de nenhum sintoma de apodrecimento radicular. As cultivares Elisa e Lucy Brown foram bastante sensíveis ao isolado $\mathrm{A}_{2}$. Com relação ao isolado $\mathrm{CH}$, Lucy Brown exibiu apenas traços de necrose nas raízes das plantas inoculadas e Elisa apresentou severidade intermediária (Tabela 7, Figura 9, Apêndice 15).

Com respeito à redução do comprimento de plantas inoculadas (Tabela 7), o isolado $\mathrm{A}_{2}$ foi o mais agressivo, ocasionando 41,63 e 41,47 \% de restrição do crescimento das cultivares suscetíveis Lucy Brown e Elisa, respectivamente. Entre as cultivares que exibiram resistência, apenas na New Red Fire o isolado $\mathrm{A}_{2}$ ocasionou subdesenvolvimento estatisticamente significativo. Nas demais, o crescimento das plantas inoculadas não diferiu das plantas controles. $\mathrm{O}$ isolado $\mathrm{CH}$ também causou redução do comprimento de plantas nas cultivares Elisa, Lucy Brown e New Red Fire. Nas duas primeiras, proporcionou restrição do crescimento bem inferior ao isolado $\mathrm{A}_{2}$. $\mathrm{Na}$ cv. New Red Fire, ocasionou subdesenvolvimento similar a $\mathrm{A}_{2}$. Em Raider e Vera não causou subdesenvolvimento. Para a cv. Warrior, a restrição do crescimento foi desprezível. As plantas de Vera inoculadas com os dois isolados e as de Raider, inoculadas com $\mathrm{CH}$, exibiram comprimentos maiores que as testemunhas, destacando-se 
Tabela 7. Reação de cultivares de alface aos isolados $\mathrm{A}_{2}$ e CH de Thielaviopsis basicola. Piracicaba, 2004

\begin{tabular}{|c|c|c|c|c|c|c|c|c|c|c|c|c|}
\hline \multirow{3}{*}{$\begin{array}{c}\text { Cultivar } \\
\text { Elisa }\end{array}$} & \multicolumn{4}{|c|}{ Nota $^{1,2}$} & \multicolumn{6}{|c|}{ Comprimento da planta $(\mathrm{cm})^{1,3}$} & \multicolumn{2}{|c|}{$\begin{array}{c}\text { \% Redução } \\
\text { comprimento }\end{array}$} \\
\hline & \multicolumn{2}{|c|}{$\mathbf{A}_{2}$} & \multicolumn{2}{|c|}{$\mathbf{C H}$} & \multicolumn{2}{|c|}{ Testemunha } & \multicolumn{2}{|c|}{$\mathbf{A}_{2}$} & \multicolumn{2}{|c|}{$\mathbf{C H}$} & \multirow{2}{*}{$\begin{array}{c}\mathbf{A}_{2} \\
41,47\end{array}$} & \multirow{2}{*}{$\begin{array}{c}\mathbf{C H} \\
17,39\end{array}$} \\
\hline & 4,60 & a A & 2,40 & a B & 59,80 & a A & 35,00 & $\mathrm{c} \mathrm{C}$ & 49,40 & bc B & & \\
\hline Lucy Brown & 4,60 & a A & 2,00 & a B & 53,80 & bc A & 31,40 & c C & 45,60 & c B & 41,63 & 15,24 \\
\hline Raider & 1,40 & b A & 1,20 & b A & 56,60 & $\mathrm{ab} \mathrm{AB}$ & 51,20 & a B & 57,00 & a A & 9,54 & $-0,71$ \\
\hline Warrior & 1,20 & b A & 1,20 & b A & 49,60 & c A & 45,20 & $\mathrm{~b} A$ & 48,40 & $\mathrm{c} A$ & 8,87 & 2,42 \\
\hline New Red Fire & 1,20 & $\mathrm{~b} A$ & 1,20 & $\mathrm{~b} A$ & 54,00 & bc A & 47,00 & $\mathrm{ab} B$ & 47,60 & $\mathrm{c} \mathrm{B}$ & 12,96 & 11,85 \\
\hline Vera & 1,20 & b A & 1,00 & $\mathrm{~b} A$ & 48,80 & c B & 52,40 & $\mathrm{a} A B$ & 54,40 & $\mathrm{ab} A$ & $-7,38$ & $-11,47$ \\
\hline
\end{tabular}

${ }^{1}$ Média de 5 repetições, cada uma representada por um vaso com 1 planta. Médias seguidas por letras distintas minúsculas na coluna e maiúsculas na linha diferem entre si pelo teste de Tukey a 0,05 .

${ }^{2}$ Dados originais. Para efeito de análise estatística, os dados foram transformados em raiz quadrada de $\mathrm{x}+0,5(\mathrm{CV}=11,90 \%)$.

${ }^{3}$ Dados originais $(\mathrm{CV}=8,83 \%)$. 
as plantas da cv. Vera inoculadas com $\mathrm{CH}$, que mostraram crescimento estatisticamente superior ao das plantas testemunhas.

A massa fresca das plantas inoculadas foi mais severamente afetada pelo isolado $\mathrm{A}_{2}$ que pelo $\mathrm{CH}$ (Tabela 8). As cultivares Elisa e Lucy Brown exibiram redução de 64,65 e 57,39 \% quando inoculadas com $\mathrm{A}_{2}$ e de 32,34 e $32,36 \%$ quando inoculadas com $\mathrm{CH}$, respectivamente. $\mathrm{O}$ isolado $\mathrm{A}_{2}$ restringiu a massa fresca de Vera em 38,57 \%, de New Red Fire em 28,33 \% e de Raider em 20,33 \%. Na cv. Warrior, o mesmo isolado também ocasionou redução, porém, os valores da massa fresca de plantas inoculadas e não inoculadas não foram estatisticamente diferentes. As massas frescas de Raider, New Red Fire, Warrior e Vera inoculadas com $\mathrm{CH}$ não apresentaram diferenças estatísticas das plantas não inoculadas, entretanto, houve redução de 18,87 \% da massa fresca das plantas de Raider inoculadas com o referido isolado.

Tabela 8. Efeito da inoculação de diferentes cultivares de alface com os isolados $\mathrm{A}_{2}$ e CH de Thielaviopsis basicola na massa fresca das plantas. Piracicaba, 2004

\begin{tabular}{|c|c|c|c|c|c|c|c|c|}
\hline \multirow{3}{*}{$\begin{array}{c}\text { Cultivar } \\
\text { Raider }\end{array}$} & \multicolumn{6}{|c|}{ Massa fresca $(g) *$} & \multicolumn{2}{|c|}{ \% Redução } \\
\hline & \multicolumn{2}{|c|}{ Testemunha } & \multicolumn{2}{|c|}{$\mathbf{A}_{2}$} & \multicolumn{2}{|c|}{$\mathbf{C H}$} & \multirow{2}{*}{$\begin{array}{c}\mathbf{A}_{2} \\
20,33\end{array}$} & \multirow{2}{*}{$\begin{array}{c}\mathbf{C H} \\
18,87\end{array}$} \\
\hline & 160,71 & a A & 128,03 & a B & 130,39 & a $\mathrm{A}$ & & \\
\hline New Red Fire & 117,11 & $\mathrm{c} \mathrm{A}$ & 83,93 & b B & 103,69 & b AB & 28,33 & 11,46 \\
\hline Warrior & 91,90 & $\mathrm{~d} A$ & 82,54 & $\mathrm{~b} A$ & 93,27 & b A & 10,18 & $-1,49$ \\
\hline Vera & 119,43 & bc A & 73,36 & bc B & 108,46 & b A & 38,57 & 9,18 \\
\hline Lucy Brown & 125,24 & bc A & 53,36 & $\mathrm{c} \mathrm{C}$ & 84,71 & b B & 57,39 & 32,36 \\
\hline Elisa & 142,21 & $\mathrm{ab} A$ & 50,27 & c C & 96,21 & b B & 64,65 & 32,34 \\
\hline
\end{tabular}

*Média de 5 repetições, cada uma representada por um vaso com 1 planta. Médias seguidas por letras distintas minúsculas na coluna e maiúsculas na linha diferem entre si pelo teste de Tukey a $0,05(\mathrm{CV}=18,71 \%)$. 


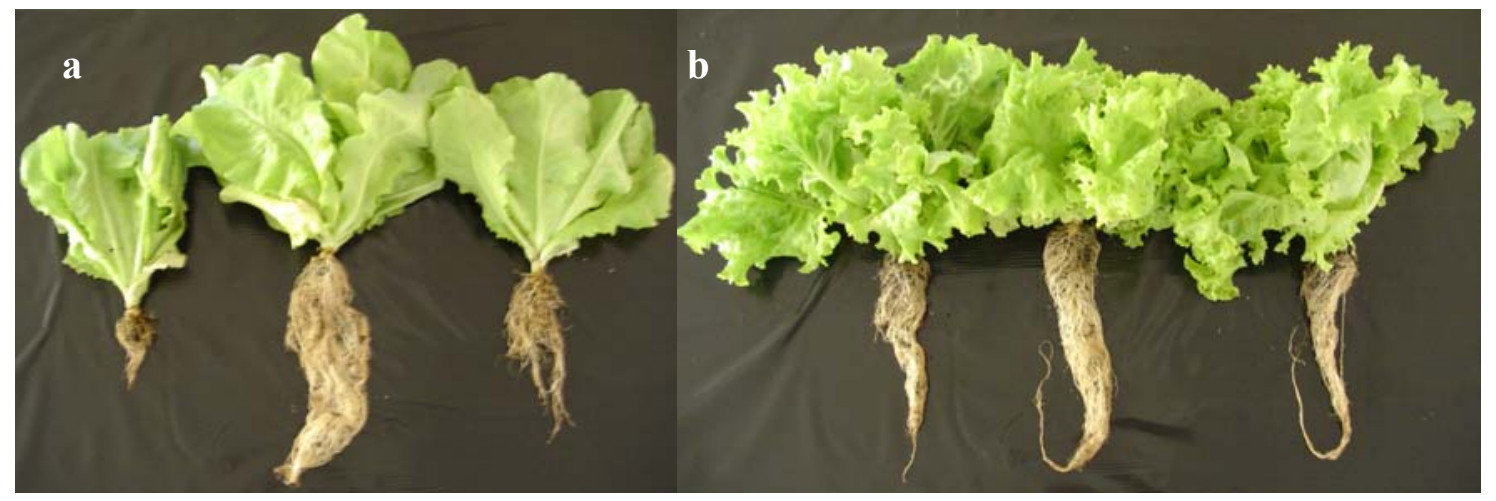

Figura 9 - Reação de cultivares de alface aos isolados $\mathrm{A}_{2}$ e $\mathrm{CH}$ de Thielaviopsis basicola. Da esquerda para a direita: planta inoculada com $\mathrm{A}_{2}$, testemunha e planta inoculada com CH. a) Cv. Elisa. b) Cv. Vera

Apesar da metodologia de inoculação e condução do presente ensaio ter sido mais eficiente que a do experimento anterior, pois permitiu mais evidente distinção entre materiais resistentes e suscetíveis (Tabelas 7 e 8, Figura 9, Apêndice 15), não houve diferença na reação das cultivares testadas aos três isolados nos dois experimentos. Entretanto, o isolado $\mathrm{CH}$ foi claramente menos agressivo que $\mathrm{A}_{2}$. Assim, contrariou as suspeitas iniciais que o mesmo seria capaz - como ocorre com Pythium spp. - de ocasionar infecção subclínica (Stanghellini \& Kronland, 1986) em alface, ou seja, reduzir consistentemente a produtividade da cultura na ausência de qualquer sintoma de apodrecimento radicular.

O emprego de cultivares resistentes é o meio mais prático, eficaz e econômico de controle da podridão negra da raiz ocasionada por T. basicola. É a principal medida de controle do patógeno na cultura de fumo do tipo Burley nos EUA (Hood \& Shew, 1996). No Brasil, como as variedades de alface do tipo crespa representam $70 \%$ do mercado desta folhosa, surpreendentemente, a resistência genética das cultivares crespas vem desempenhando papel fundamental no controle da doença. No entanto, para os cultivos de alface dos tipos lisa e americana, outras práticas de controle devem ser adotadas. Além disso, é de suma importância a busca por outras fontes de resistência, 
pois, como foi demonstrado por Sala et al. (2004a), a resistência de alface a T. basicola é conferida por um gene dominante. Pode ser que esse gene proporcione uma resistência durável como ocorre na cultivar de fumo TN 86 (Wilkinson et al., 1991). Por outro lado, cultivares com um gene de resistência, do tipo vertical, são bastante vulneráveis ao aparecimento de novas raças virulentas do patógeno.

\subsection{Efeito de fungicidas sobre o crescimento micelial e a esporulação de Thielaviopsis basicola}

Os isolados $\mathrm{L}_{1}, \mathrm{~A}_{2}$ e $\mathrm{CH}$ de Thielaviopsis basicola foram avaliados com relação a sua sensibilidade in vitro a fungicidas e os resultados estão apresentados nas Tabelas 9 a 14, Figura 10 e Apêndices 16 a 21. A análise estatística dos resultados evidenciou interações significativas entre fungicidas e concentrações ( $1^{\circ}$ ensaio - Apêndice 16) e entre fungicidas, concentrações e isolados ( $2^{\circ}$ ensaio - Apêndice 19); o teste de comparação de médias foi realizado entre os fungicidas ( $1^{\circ}$ ensaio) e entre os fungicidas e isolados ( $2^{\circ}$ ensaio) dentro de cada concentração (Johnson \& Berger, 1982), tanto para os dados de porcentagem de inibição do crescimento micelial em relação à testemunha (Tabelas 9 e 10), quanto para os dados de porcentagem de inibição da esporulação em relação à testemunha (Tabelas 12 e 13).

De acordo com o observado na Figura 10 e Apêndices 17 e 20, com o incremento na concentração de fungicidas, houve um decréscimo no crescimento micelial dos três isolados testados. Observando-se a Tabela 11, na qual são exibidos os valores de $\mathrm{ED}_{90}$ para o crescimento micelial dos isolados, constata-se que o fungicida carbendazim foi muito efetivo para o isolado $\mathrm{L}_{1}$, reduzindo $90 \%$ de seu crescimento em concentração abaixo de $0,1 \mathrm{ppm}$; carbendazim e benomyl foram os mais eficientes na inibição de $\mathrm{A}_{2}$ e carbendazim, benomyl e cyproconazole controlaram de forma eficaz o isolado $\mathrm{CH}$. Cyproconazole reduziu o crescimento micelial de $\mathrm{L}_{1}$ e $\mathrm{CH}$ com maior eficácia que de $\mathrm{A} 2$, enquanto $\mathrm{L}_{1}$ foi mais sensível a tiofanato metílico e tebuconazole que $\mathrm{A}_{2}$ e $\mathrm{CH}$. Triadimenol e hexaconazole+chlorothalonil inibiram de maneira similar os três isolados, restringiram $90 \%$ do crescimento micelial em concentrações entre 1 e 10 ppm e entre 10 e 100 ppm, respectivamente. Com respeito aos produtos azoxystrobin e 
Tabela 9. Eficiência de fungicidas, a 0,$1 ; 1 ; 10$ e 100 ppm, na inibição do crescimento micelial do isolado $\mathrm{L}_{1}$ de Thielaviopsis basicola. Piracicaba, 2003

\begin{tabular}{|c|c|c|c|c|c|c|c|c|}
\hline \multirow{3}{*}{$\begin{array}{l}\text { Fungicida } \\
\text { carbendazim }\end{array}$} & \multicolumn{8}{|c|}{ Porcentagem de Inibição do Crescimento* } \\
\hline & \multicolumn{2}{|c|}{$\mathbf{0 , 1}$} & \multirow{2}{*}{\multicolumn{2}{|c|}{$\begin{array}{l}1 \\
0 \mathrm{a}\end{array}$}} & \multicolumn{2}{|c|}{10} & \multicolumn{2}{|c|}{100} \\
\hline & 96,26 & $\mathrm{a}$ & & & 100,00 & a & 100,00 & $\mathrm{a}$ \\
\hline benomyl & 79,25 & $\mathrm{~b}$ & 100,00 & $\mathrm{a}$ & 99,88 & $\mathrm{a}$ & 100,00 & $\mathrm{a}$ \\
\hline cyproconazole & 63,73 & $\mathrm{c}$ & 92,20 & $\mathrm{~b}$ & 100,00 & $\mathrm{a}$ & 100,00 & $\mathrm{a}$ \\
\hline $\begin{array}{l}\text { tiofanato } \\
\text { metílico }\end{array}$ & 4,17 & g & 93,17 & $\mathrm{~b}$ & 100,00 & $\mathrm{a}$ & 100,00 & $\mathrm{a}$ \\
\hline propiconazole & 60,35 & $\mathrm{c}$ & 92,91 & $\mathrm{~b}$ & 99,80 & $\mathrm{a}$ & 99,58 & $\mathrm{a}$ \\
\hline tebuconazole & 51,08 & d & 91,41 & $\mathrm{~b}$ & 97,85 & $\mathrm{~b}$ & 100,00 & $\mathrm{a}$ \\
\hline triadimenol & 33,45 & e & 81,01 & $\mathrm{c}$ & 96,65 & $\mathrm{~b}$ & 100,00 & $\mathrm{a}$ \\
\hline $\begin{array}{c}\text { hexaconazole+ } \\
\text { chlorothalonil }\end{array}$ & 7,36 & g & 52,68 & $\mathrm{~d}$ & 87,94 & $\mathrm{c}$ & 100,00 & $\mathrm{a}$ \\
\hline azoxystrobin & 23,50 & $\mathrm{f}$ & 34,62 & e & 36,87 & $\mathrm{~d}$ & 55,61 & $\mathrm{~b}$ \\
\hline
\end{tabular}

*Média de quatro repetições, cada uma representada por uma placa de Petri. Médias seguidas por letras distintas diferem entre si (para cada dose separadamente) pelo teste de Tukey a 0,05 $(\mathrm{CV}=2,63 \%)$.

Dados originais. Para efeito de análise estatística, os dados foram transformados em arco seno da raiz de $\mathrm{x} / 100$. 
Tabela 10. Eficiência de fungicidas, a 0,$1 ; 1 ; 10$ e 100 ppm, na inibição do crescimento micelial dos isolados $\mathrm{A}_{2}$ e $\mathrm{CH}_{\text {de }}$ Thielaviopsis basicola. Piracicaba, 2004

\begin{tabular}{|c|c|c|c|c|c|c|c|c|}
\hline \multirow{3}{*}{ Fungicida } & \multicolumn{8}{|c|}{ Porcentagem de Inibição do Crescimento* } \\
\hline & \multicolumn{2}{|c|}{$\mathbf{0 , 1}$} & \multicolumn{2}{|c|}{$\mathbf{1}$} & \multicolumn{2}{|c|}{10} & \multicolumn{2}{|c|}{100} \\
\hline & $\mathbf{A}_{2}$ & $\mathbf{C H}$ & $\mathbf{A}_{2}$ & CH & $\mathbf{A}_{2}$ & $\mathbf{C H}$ & $\mathbf{A}_{2}$ & $\mathbf{C H}$ \\
\hline carbendazim & $25,65 \mathrm{c} \mathrm{A}$ & $26,61 \mathrm{c} \mathrm{A}$ & 100,00 a $\mathrm{A}$ & 100,00 a $\mathrm{A}$ & 100,00 a $\mathrm{A}$ & 100,00 a $\mathrm{A}$ & 100,00 a $\mathrm{A}$ & 100,00 a A \\
\hline benomyl & 1,25 e B & $13,47 \mathrm{~d} A$ & 100,00 a $\mathrm{A}$ & 100,00 a A & 100,00 a A & 100,00 a A & 100,00 a $\mathrm{A}$ & 100,00 a A \\
\hline cyproconazole & 67,63 a $A$ & 68,42 a A & $88,44 \mathrm{~b} \mathrm{~A}$ & $90,79 \mathrm{~b} \mathrm{~A}$ & 100,00 a A & 100,00 a A & 100,00 a A & 100,00 a A \\
\hline tiofanato metílico & $10,69 \mathrm{~d} A$ & 11,40 de $\mathrm{A}$ & $27,88 \mathrm{c} \mathrm{A}$ & 25,75 e $\mathrm{A}$ & 100,00 a $\mathrm{A}$ & 100,00 a $\mathrm{A}$ & 100,00 a $\mathrm{A}$ & 100,00 a $\mathrm{A}$ \\
\hline tebuconazole & $44,23 \mathrm{~b} \mathrm{~A}$ & $47,49 \mathrm{~b} \mathrm{~A}$ & 84,19 b A & 68,04 c B & 99,57 a A & 99,09 ab A & 100,00 a $\mathrm{A}$ & 100,00 a A \\
\hline triadimenol & 35,38 bc A & $39,49 \mathrm{~b} \mathrm{~A}$ & $84,94 \mathrm{~b} \mathrm{~A}$ & $84,71 \mathrm{~b} \mathrm{~A}$ & 92,47 b A & $97,34 \mathrm{~b} \mathrm{~A}$ & 100,00 a $\mathrm{A}$ & 100,00 a A \\
\hline $\begin{array}{l}\text { hexaconazole+ } \\
\text { chlorothalonil }\end{array}$ & 2,17 e $\mathrm{B}$ & 6,60 e $A$ & 19,44 с B & $40,30 \mathrm{~d} A$ & $79,11 \mathrm{c} \mathrm{A}$ & $77,61 \mathrm{c} \mathrm{A}$ & 100,00 a $\mathrm{A}$ & 99,55 a $\mathrm{A}$ \\
\hline
\end{tabular}

*Média de três repetições, cada uma representada por uma placa de Petri. Médias seguidas por letras distintas minúsculas na coluna e maiúsculas na linha (para cada dose separadamente) diferem entre si pelo teste de Tukey a $0,05(\mathrm{CV}=2,88 \%)$.

Dados originais. Para efeito de análise estatística, os dados foram transformados em arco seno da raiz de $\mathrm{x} / 100$. 
Tabela 11. $\mathrm{ED}_{90}$ dos fungicidas testados para a inibição do crescimento micelial de três isolados de Thielaviopsis basicola

\begin{tabular}{cccc}
\hline Fungicidas & $\mathbf{1}^{\mathbf{0}}$ ensaio & \multicolumn{2}{c}{$\mathbf{2}^{\mathbf{0}}$ ensaio } \\
& $\mathbf{L}_{\mathbf{1}}$ & $\mathbf{A}_{\mathbf{2}}$ & $\mathbf{C H}$ \\
\hline carbendazim & $0-0,1$ & $0,1-1$ & $0,1-1$ \\
benomyl & $0,1-1$ & $0,1-1$ & $0,1-1$ \\
cyproconazole & $0,1-1$ & $1-10$ & $0,1-1$ \\
tiofanato metílico & $0,1-1$ & $1-10$ & $1-10$ \\
tebuconazole & $0,1-1$ & $1-10$ & $1-10$ \\
triadimenol & $1-10$ & $1-10$ & $1-10$ \\
hexaconazole+chlorothalonil & $10-100$ & $10-100$ & $10-100$ \\
propiconazole & $0,1-1$ & $\mathrm{NT}$ & $\mathrm{NT}$ \\
azoxystrobin & $>100$ & $\mathrm{NT}$ & $\mathrm{NT}$ \\
\hline
\end{tabular}

*NT = Não foi testado.

propiconazole, testados apenas para $L_{1}$, somente o último foi eficiente na inibição do micélio. Todos os fungicidas avaliados, na concentração de 100 ppm, foram capazes de erradicar o micélio dos três isolados de T. basicola, exceto azoxystrobin e propiconazole para $\mathrm{L}_{1}$ (Tabela 9) e a mistura hexaconazole+chlorothalonil para $\mathrm{CH}$ (Tabela 10). Entretanto, a inibição do crescimento micelial ocasionada por propiconazole e hexaconazole+chlorothalonil para os respectivos isolados, não diferiu estatisticamente da inibição de $100 \%$ determinada pelos demais fungicidas.

Com o aumento da concentração de fungicidas, também ocorreu a diminuição da esporulação dos três isolados de T. basicola, conforme é ilustrado nos Apêndices 18 e 21. Observando-se a Tabela 14, é possível constatar que os fungicidas mais eficientes na inibição da esporulação foram: carbendazim, para os isolados $\mathrm{L}_{1}$ e $\mathrm{CH}$ e carbendazim e benomyl para $\mathrm{A}_{2}$. Na faixa de concentração entre 0,1 e 1 ppm, benomyl restringiu em 90\% a esporulação dos três isolados. Cyproconazole foi mais efetivo para $\mathrm{CH}$ que para 
Tabela 12. Eficiência de fungicidas, a 0,$1 ; 1 ; 10$ e 100 ppm, na inibição da esporulação do isolado $\mathrm{L}_{1}$ de Thielaviopsis basicola. Piracicaba, 2003

\begin{tabular}{|c|c|c|c|c|c|c|c|c|}
\hline \multirow{3}{*}{$\begin{array}{l}\text { Fungicida } \\
\text { carbendazim }\end{array}$} & \multicolumn{8}{|c|}{ Porcentagem de Inibição da Esporulação* } \\
\hline & \multicolumn{2}{|c|}{0,1} & \multicolumn{2}{|c|}{1} & \multicolumn{2}{|c|}{10} & \multicolumn{2}{|c|}{100} \\
\hline & 99,32 & $\mathrm{a}$ & 100,00 & $\mathrm{a}$ & 100,00 & $\mathrm{a}$ & 100,00 & $\mathrm{a}$ \\
\hline benomyl & 84,92 & $\mathrm{~b}$ & 100,00 & $\mathrm{a}$ & 100,00 & $\mathrm{a}$ & 100,00 & $\mathrm{a}$ \\
\hline $\begin{array}{l}\text { tiofanato } \\
\text { metílico }\end{array}$ & 46,72 & $\mathrm{f}$ & 98,83 & $\mathrm{~b}$ & 100,00 & $\mathrm{a}$ & 100,00 & $\mathrm{a}$ \\
\hline cyproconazole & 68,59 & de & 86,48 & $\mathrm{~d}$ & 100,00 & $\mathrm{a}$ & 100,00 & $\mathrm{a}$ \\
\hline tebuconazole & 76,73 & $\mathrm{c}$ & 91,33 & $\mathrm{c}$ & 99,30 & $\mathrm{~b}$ & 100,00 & $\mathrm{a}$ \\
\hline triadimenol & 70,31 & $\mathrm{~d}$ & 82,22 & de & 96,35 & $\mathrm{c}$ & 100,00 & $\mathrm{a}$ \\
\hline propiconazole & 79,75 & $\mathrm{bc}$ & 85,03 & de & 99,83 & $\mathrm{a}$ & 99,95 & $\mathrm{a}$ \\
\hline $\begin{array}{l}\text { hexaconazole+ } \\
\text { chlorothalonil }\end{array}$ & 64,42 & $\mathrm{e}$ & 80,43 & e & 87,58 & $\mathrm{~d}$ & 100,00 & $\mathrm{a}$ \\
\hline azoxystrobin & 44,90 & $\mathrm{f}$ & 54,81 & $f$ & 68,65 & $\mathrm{e}$ & 80,25 & $\mathrm{~b}$ \\
\hline
\end{tabular}

*Média de quatro repetições, cada uma representada por uma placa de Petri. Médias seguidas por letras distintas diferem entre si (para cada dose separadamente) pelo teste de Tukey a 0,05 $(\mathrm{CV}=1,67 \%)$.

Dados originais. Para efeito de análise estatística, os dados foram transformados em arco seno da raiz de $\mathrm{x} / 100$. 
Tabela 13. Eficiência de fungicidas, a 0,1; 1; 10 e 100 ppm, na inibição da esporulação dos isolados $\mathrm{A}_{2}$ e $\mathrm{CH}$ de Thielaviopsis basicola. Piracicaba, 2004

\begin{tabular}{|c|c|c|c|c|c|c|c|c|}
\hline \multirow{3}{*}{ Fungicida } & \multicolumn{8}{|c|}{ Porcentagem de Inibição da Esporulação* } \\
\hline & \multicolumn{2}{|c|}{0,1} & \multicolumn{2}{|c|}{1} & \multicolumn{2}{|c|}{10} & \multicolumn{2}{|c|}{100} \\
\hline & $\mathbf{A}_{2}$ & $\mathbf{C H}$ & $\mathbf{A}_{2}$ & $\mathbf{C H}$ & $\mathbf{A}_{2}$ & $\mathbf{C H}$ & $\mathbf{A}_{2}$ & $\mathbf{C H}$ \\
\hline carbendazim & 53,65 b B & 99,19 a $\mathrm{A}$ & 100,00 a $\mathrm{A}$ & 100,00 a $\mathrm{A}$ & 100,00 a $\mathrm{A}$ & 100,00 a $\mathrm{A}$ & 100,00 a $\mathrm{A}$ & 100,00 a $\mathrm{A}$ \\
\hline benomyl & 29,86 c A & $30,64 \mathrm{~d} \mathrm{~A}$ & 100,00 a $\mathrm{A}$ & 100,00 a $\mathrm{A}$ & 100,00 a $\mathrm{A}$ & 100,00 a $\mathrm{A}$ & 100,00 a $\mathrm{A}$ & 100,00 a $\mathrm{A}$ \\
\hline cyproconazole & 66,71 a $\mathrm{A}$ & $66,95 \mathrm{~b} \mathrm{~A}$ & 85,86 b B & $94,73 \mathrm{~b} \mathrm{~A}$ & 100,00 a $\mathrm{A}$ & 100,00 a $\mathrm{A}$ & 100,00 a $\mathrm{A}$ & 100,00 a $\mathrm{A}$ \\
\hline tiofanato metílico & $12,72 \mathrm{~d} A$ & $2,99 \mathrm{fB}$ & $47,84 \mathrm{c} \mathrm{A}$ & $22,04 \mathrm{~d} B$ & 100,00 a $\mathrm{A}$ & 100,00 a $\mathrm{A}$ & 100,00 a $\mathrm{A}$ & 100,00 a A \\
\hline tebuconazole & 66,98 a A & 53,17 c B & 88,97 b A & $82,84 \mathrm{c} \mathrm{A}$ & $99,79 \mathrm{ab} A$ & $99,21 \mathrm{ab} A$ & 100,00 a $\mathrm{A}$ & 100,00 a $A$ \\
\hline triadimenol & 39,73 с A & $40,70 \mathrm{~d} A$ & 82,96 b B & $94,07 \mathrm{~b} \mathrm{~A}$ & $97,66 \mathrm{~b} \mathrm{~A}$ & $97,97 \mathrm{bc} \mathrm{A}$ & 100,00 a A & 100,00 a $\mathrm{A}$ \\
\hline $\begin{array}{l}\text { hexaconazole+ } \\
\text { chlorothalonil }\end{array}$ & 6,67 e B & 13,46 e $A$ & 39,44 c B & $74,91 \mathrm{c} \mathrm{A}$ & 90,42 c A & $94,95 \mathrm{c} \mathrm{A}$ & 100,00 a $\mathrm{A}$ & 100,00 a $A$ \\
\hline
\end{tabular}

*Média de três repetições, cada uma representada por uma placa de Petri. Médias seguidas por letras distintas minúsculas na coluna e maiúsculas na linha (para cada dose separadamente) diferem entre si pelo teste de Tukey a 0,05 (CV=2,80 \%).

Dados originais. Para efeito de análise estatística, os dados foram transformados em arco seno da raiz de $\mathrm{x} / 100$. 
Tabela 14. $\mathrm{ED}_{90}$ dos fungicidas testados para a inibição da esporulação de três isolados de Thielaviopsis basicola

\begin{tabular}{cccc}
\hline Fungicidas & $\mathbf{1}^{\mathbf{0}}$ ensaio & \multicolumn{2}{c}{$\mathbf{2}^{\mathbf{o}}$ ensaio } \\
& $\mathbf{L}_{\mathbf{1}}$ & $\mathbf{A}_{\mathbf{2}}$ & $\mathbf{C H}$ \\
\hline carbendazim & $0-0,1$ & $0,1-1$ & $0-0,1$ \\
benomyl & $0,1-1$ & $0,1-1$ & $0,1-1$ \\
cyproconazole & $1-10$ & $1-10$ & $0,1-1$ \\
tiofanato metílico & $0,1-1$ & $1-10$ & $1-10$ \\
tebuconazole & $0,1-1$ & $1-10$ & $1-10$ \\
triadimenol & $0,1-1$ & $1-10$ & $0,1-1$ \\
hexaconazole+chlorothalonil & $10-100$ & $1-10$ & $1-10$ \\
propiconazole & $1-10$ & $\mathrm{NT}$ & $\mathrm{NT}$ \\
azoxystrobin & $>100$ & $\mathrm{NT}$ & $\mathrm{NT}$ \\
\hline
\end{tabular}

*NT = Não foi testado.

$\mathrm{L}_{1}$ e $\mathrm{A}_{2}$. Tiofanato metílico e tebuconazole controlaram a esporulação de forma mais eficaz para $L_{1}$ que para os outros dois isolados, semelhante ao que ocorreu na inibição do crescimento micelial. Triadimenol foi mais eficiente para $L_{1}$ e $C H$ que para $A_{2}$, e a mistura hexaconazole+chlorothalonil foi mais efetiva para $\mathrm{A}_{2}$ e $\mathrm{CH}$ que para $\mathrm{L}_{1}$. Quanto aos fungicidas avaliados apenas para o isolado $\mathrm{L}_{1}$, somente o propiconazole inibiu satisfatoriamente a esporulação do referido isolado. Todos os fungicidas pesquisados suprimiram a esporulação dos três isolados na concentração de 100 ppm, exceto propiconazole e azoxystrobin para $\mathrm{L}_{1}$. Entretanto, apenas o azoxystrobin ocasionou uma porcentagem de inibição da esporulação estatisticamente diferente daquelas proporcionadas pelos outros produtos nessa concentração (Tabelas 12 e 13).

De modo geral, os três isolados de T. basicola foram mais sensíveis ao fungicida carbendazim, tanto em termos de crescimento micelial quanto da esporulação. 


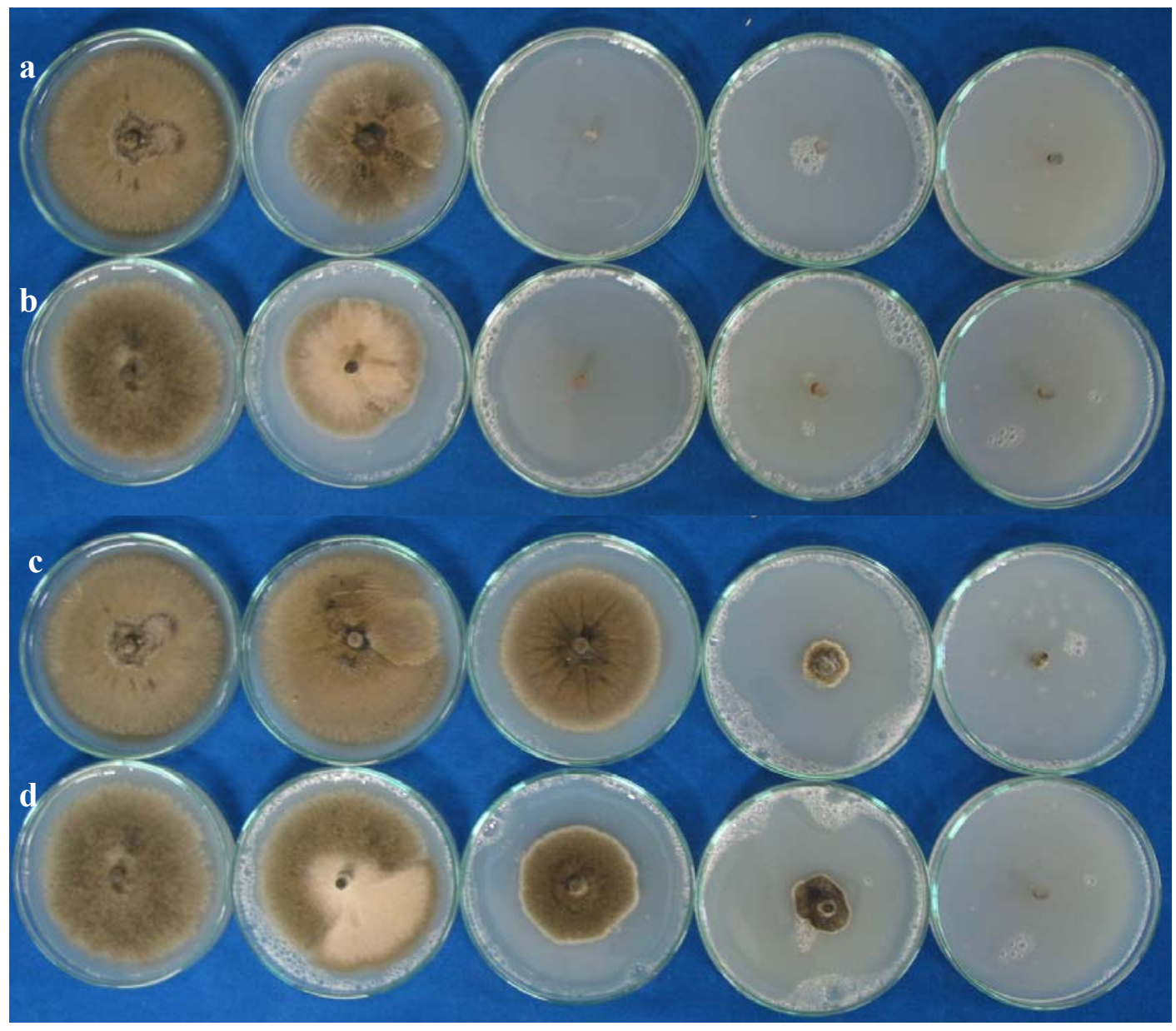

Figura 10 - Sensibilidade dos isolados $\mathrm{A}_{2}$ e $\mathrm{CH}$ de Thielaviopsis basicola a fungicidas. Da esquerda para a direita: $0 ; 0,1 ; 1,10$ e $100 \mathrm{mg} / \mathrm{L}$ de ingrediente ativo. a) carbendazim / isolado $\mathrm{A}_{2}$. b) carbendazim / isolado $\mathrm{CH}$. c) hexaconazole+chlorothalonil / isolado $A_{2}$ e d) hexaconazole+chlorothalonil / isolado $\mathrm{CH}$

Para o isolado $L_{1}$, carbendazim foi o mais eficiente na inibição tanto do crescimento micelial quanto da esporulação. Para $A_{2}$, carbendazim e benomyl destacaram-se. Carbendazim, benomyl e cyproconazole inibiram eficientemente o crescimento micelial e carbendazim, a esporulação de $\mathrm{CH}$. Esses resultados estão de acordo com o que foi encontrado por outros pesquisadores. Prinsloo et al. (1989) 
constataram que o crescimento micelial de T. basicola, isolado de fumo, foi completamente inibido por benomyl a $1 \mathrm{mg} / \mathrm{L}$ e triadimenol a $10 \mathrm{mg} / \mathrm{L}$ de ingrediente ativo. Edgington et al. (1971) verificaram que o fungicida benomyl, na concentração de $0,2 \mathrm{ppm}$ reduziu $50 \%$ do crescimento micelial de T. basicola in vitro. Segundo os últimos autores, um fungo é altamente sensível a certo fungicida quando exibe um valor de $\mathrm{ED}_{50}$ (concentração de ingrediente ativo necessária para a inibição de $50 \%$ da população do fungo) menor que $1 \mathrm{ppm}$, moderadamente sensível quando o $\mathrm{ED}_{50}$ situa-se entre 1 e 10 ppm e insensível quando o $\mathrm{ED}_{50}$ é igual ou maior que $50 \mathrm{ppm}$. Aplicando-se tal classificação aos resultados obtidos, o isolado $\mathrm{L}_{1}$ pode ser considerado altamente sensível a todos os produtos avaliados, tanto em termos de esporulação quanto de crescimento micelial, exceto ao fungicida azoxystrobin, com relação ao crescimento micelial. Os isolados $\mathrm{A}_{2}$ e $\mathrm{CH}$ podem ser classificados como altamente sensíveis, quanto ao crescimento micelial e esporulação, aos fungicidas carbendazim, benomyl, cyproconazole, tebuconazole e triadimenol. Com respeito ao tiofanato metílico, são considerados moderadamente sensíveis. Considerando-se a mistura hexaconazole + chlorothalonil, os dois isolados são moderadamente sensíveis em relação ao crescimento micelial. Quanto à esporulação, $\mathrm{A}_{2}$ é moderadamente sensível e $\mathrm{CH}$ é altamente sensível.

Tosi \& Zazzerini (1992) avaliaram o efeito dos produtos benomyl, thiabendazole, triadimenol, iprodione, vinclozolin, fosetyl-Al, tolclofos-methyl, dazomet e metham-sodium sobre o crescimento micelial in vitro e na densidade de inóculo, em condições de casa-de-vegetação, de um isolado de T. basicola proveniente da cultura de fumo. De acordo com os autores, a completa inibição do crescimento micelial ocorreu com benomyl a 2,5, 5, 10, 20, 40 e 80 ppm; thiabendazole nas mesmas concentrações (exceto a 2,5 ppm); triadimenol a 10, 20, 40 e $80 \mathrm{ppm}$ e dazomet a 40 e $80 \mathrm{ppm}$. FosetylAl e metham-sodium reduziram significativamente o micélio do fungo a 40 e $80 \mathrm{ppm}$. Os demais produtos foram ineficientes na redução do crescimento micelial. Benomyl, thiabendazole e tolclofos-methyl a $100 \mathrm{ppm}$, triadimenol a $8 \mathrm{ppm}$ e dazomet a $200 \mathrm{ppm}$ ocasionaram considerável redução da densidade de inóculo de T. basicola in vivo, após 45 dias da aplicação como rega. Apenas benomyl e dazomet suprimiram completamente os esporos do fungo no solo. Como existe uma forte correlação entre a densidade de 
inóculo de T. basicola no solo e a severidade da podridão negra da raiz, já demonstrada em vários patossistemas (Bhatti \& Kraft, 1992a; Holtz \& Weinhold, 1994; Hsi \& Ortiz Jr., 1980; Meyer \& Shew, 1991), fungicidas que reduzam a esporulação do patógeno podem ser importantes armas no controle da doença. Apesar dos resultados apresentados serem apenas preliminares, pois foram obtidos em condições de laboratório, demonstram o grande potencial de controle da esporulação de $T$. basicola pelos fungicidas carbendazim e benomyl, com grande destaque para carbendazim.

\subsection{Efeito de fungicidas no controle de Thielaviopsis basicola in vivo}

De acordo com a análise estatística dos dados, houve efeito significativo da aplicação de fungicidas no controle da podridão negra da raiz de alface, em condições de casa-de-vegetação, para os dois parâmetros avaliados, nota e comprimento de plantas (Apêndice 22).

Todos os produtos estudados reduziram a severidade da doença, diferindo estatisticamente da testemunha inoculada e não tratada (Tabela 15). O fungicida tebuconazole apresentou excepcional efeito sobre a severidade da doença, pois evitou o aparecimento de qualquer sintoma de apodrecimento radicular. A aplicação dos demais produtos, com exceção de benomyl, resultou em notas para severidade da doença que não foram estatisticamente diferentes da testemunha não inoculada, sugerindo satisfatório controle da doença. Considerando-se o comprimento das plantas, os tratamentos com todos os fungicidas proporcionaram consistentes incrementos no crescimento das mesmas, em relação à testemunha inoculada e não tratada. O fungicida triadimenol permitiu a produção de plantas com excelente aspecto (Figura 11), muito vigorosas e com comprimento estatisticamente igual ao da testemunha não inoculada (Tabela 15). 
Tabela 15. Efeito de fungicidas sobre a severidade da podridão negra da raiz e o comprimento de plantas, em condições de casa-de-vegetação. Piracicaba, 2003

\begin{tabular}{crlcl}
\hline Tratamento & Nota $^{1,2}$ & $\begin{array}{c}\text { Comprimento da } \\
\text { planta }(\mathbf{c m})^{1}\end{array}$ \\
\hline Testemunha inoculada & 4,22 & $\mathrm{a}$ & 29,89 & $\mathrm{c}$ \\
benomyl & 2,11 & $\mathrm{~b}$ & 43,44 & $\mathrm{~b}$ \\
tiofanato metílico & 1,89 & $\mathrm{bc}$ & 42,56 & $\mathrm{~b}$ \\
cyproconazole & 1,78 & $\mathrm{bc}$ & $41,44 \mathrm{~b}$ \\
hexaconazole+chlorothalonil & 1,67 & $\mathrm{bc}$ & $42,89 \mathrm{~b}$ \\
carbendazim & 1,33 & $\mathrm{bc}$ & $43,89 \mathrm{~b}$ \\
triadimenol & $1,22 \mathrm{bc}$ & $45,33 \mathrm{ab}$ \\
tebuconazole & 1,00 & $\mathrm{c}$ & $41,56 \mathrm{~b}$ \\
Testemunha não inoculada & 1,00 & $\mathrm{c}$ & $49,33 \mathrm{a}$ \\
CV (\%) & 14,50 & & 8,48 \\
\hline
\end{tabular}

${ }^{1}$ Média de 9 repetições, cada uma representada por um vaso com uma planta. Médias seguidas por letras distintas diferem entre si pelo teste de Tukey a 0,05 .

${ }^{2}$ Dados originais. Para efeito de análise estatística, os dados foram transformados em raiz quadrada de $\mathrm{x}+0,5$.

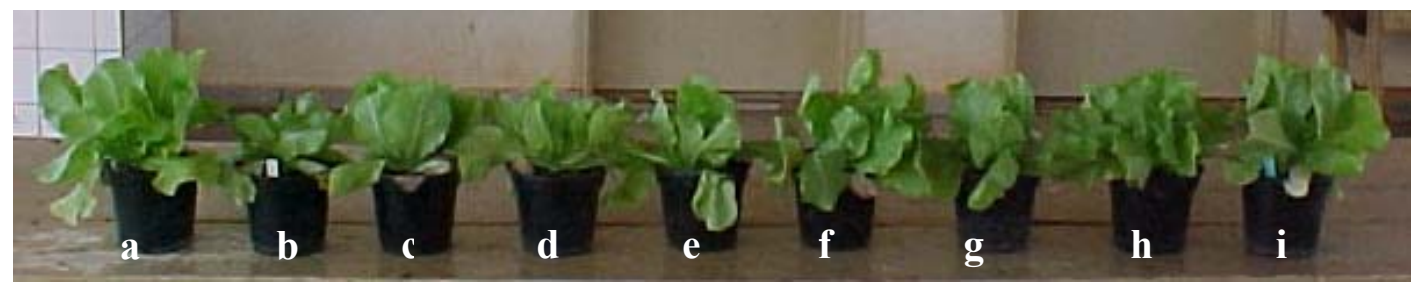

Figura 11 - Efeito de fungicidas no controle da podridão negra da raiz de alface. Aspecto das plantas nos seguintes tratamentos: a) testemunha não inoculada e não tratada, b) testemunha inoculada e não tratada, c) cyproconazole, d) benomyl, e) tiofanato metílico, f) carbendazim, g) hexaconazole+chlorothalonil, h) tebuconazole e i) triadimenol 
O emprego de fungicidas foi um eficiente método de controle de Thielaviopsis basicola na cultura de alface, confirmando os resultados obtidos in vitro (item 4.4) e por outros pesquisadores. O`Brien \& Davis (1994) também controlaram consistentemente a podridão negra da raiz de alface, em condições de casa-de-vegetação, através de regas com benomyl (500 mg / L) e propiconazole (125 mg / L), logo após o transplante das mudas. Entretanto, houve a ocorrência de leve fitotoxidez no tratamento com propiconazole. Fitotoxidez também foi observada, quando foi feita a aplicação de propiconazole (100 mg / L), na forma de rega, em experimentos preliminares em casade-vegetação. Em função de seu efeito fitóxico e do satisfatório desempenho dos demais produtos, o fungicida propiconazole foi excluído do presente ensaio.

Prinsloo et al. (1989), ao estudarem o efeito da aplicação de benomyl (3,75 g i.a. $\left./ \mathrm{m}^{2}\right)$ e de triadimenol $\left(0,0375 \mathrm{~g}\right.$ i.a. $\left./ \mathrm{m}^{2}\right)$ no controle de $T$. basicola, na cultura de fumo, em casa-de-vegetação, constataram que o tratamento com triadimenol reduziu eficientemente a severidade da doença e proporcionou mudas muito mais vigorosas que o com benomyl. Neste ensaio, a maioria das plantas que foi tratada com triadimenol apresentou ótimo aspecto, destacando-se em relação aos tratamentos com outros fungicidas e assemelhando-se à testemunha não inoculada (Figura 11).

Apesar da mistura hexaconazole + chlorothalonil não ter apresentado efeito notável sobre o patógeno em condições de laboratório (item 4.4), controlou eficientemente a doença em casa-de-vegetação. Esse é um fato relevante, pois as misturas entre fungicidas sistêmicos e protetores, além de apresentarem um amplo espectro de ação antifúngica, desempenham importante papel para evitar o aparecimento de mutantes resistentes (Cohen \& Levy, 1990).

Aplicações de benomyl e tiofanato metílico, nas linhas de plantio, no momento da semeadura, têm controlado satisfatoriamente a podridão negra da raiz de várias culturas, como fumo, feijão e poinsettia (Euphorbia pulcherrima Wild.) (Gayed, 1969; Manning et al., 1970; Papavizas et al., 1972; Raabe \& Hurlimann, 1971; Saenger, 1970). Hsi \& Ortiz Jr. (1980) encontraram que a rega com benomyl (1,7 Kg i.a / ha) e tiofanato metílico (3,2 Kg i.a. / ha) efetivamente reduziu a população de T. basicola e também a severidade da doença em amendoim. Hartill \& Campbell (1972) observaram que 
benomyl controlou T. basicola em fumo mais eficientemente que tiofanato metílico quando incorporado, na profundidade de $7,5 \mathrm{~cm}$, em canteiros de produção de mudas antes da semeadura. Quando não houve incorporação dos fungicidas ao solo, tiofanato metílico proporcionou melhor controle. No ensaio em questão, não se realizou a incorporação dos fungicidas ao substrato e o fungicida benomyl foi o menos eficiente na redução da severidade da podridão negra da raiz de alface. Talvez o controle proporcionado por esse fungicida fosse mais efetivo se o mesmo houvesse sido incorporado ao substrato após a rega. Entretanto, o benomyl não se encontra mais disponível para comercialização e os outros produtos testados apresentaram grande desempenho na redução da doença.

Os fungicidas tebuconazole, triadimenol, carbendazim, tiofanato metílico, cyproconazole e a mistura hexaconazole + chlorothalonil devem ser mais intensivamente pesquisados com o objetivo de serem registrados para a cultura de alface. Assim, no futuro, poderão ser empregados principalmente num contexto de controle integrado, associados a outras práticas de controle de T. basicola, uma ameaça que vem crescendo ano a ano nos campos comerciais de cultivo de hortaliças folhosas no Brasil.

\subsection{Efeito da solarização com e sem incorporação de matéria orgânica no controle de Thielaviopsis basicola em alface}

Houve efeito da integração entre solarização e incorporação de matéria orgânica no controle de $T$. basicola em alface. Segundo a análise estatística dos resultados, a interação entre essas duas variáveis foi significativa para os parâmetros comprimento e massa fresca de plantas e não significativa para nota (Apêndice 23).

Analisando-se os efeitos principais da incorporação de matéria orgânica e da solarização para a variável dependente nota, constata-se que a incorporação de matéria orgânica isoladamente não reduziu eficientemente a severidade da doença. Por outro lado, em todos os tratamentos solarizados, o patógeno foi controlado de forma eficaz, destacando-se aquele com incorporação de torta de mamona, que evitou o aparecimento de qualquer sintoma de necrose radicular (Tabela 16). 
Tabela 16. Efeito da incorporação de matéria-orgânica, seguida (S) ou não (NS) de solarização sobre a severidade da podridão negra da raiz, comprimento e massa fresca de plantas de alface. Piracicaba, 2004

\begin{tabular}{|c|c|c|c|c|c|c|c|c|c|c|c|c|c|}
\hline \multirow{3}{*}{$\begin{array}{c}\begin{array}{c}\text { Matéria } \\
\text { orgânica }\end{array} \\
\begin{array}{c}\text { Torta } \\
\text { Mamona }\end{array}\end{array}$} & \multicolumn{4}{|c|}{ Nota ${ }^{1,2}$} & \multicolumn{5}{|c|}{ Comprimento planta $(\mathrm{cm})^{1}$} & \multicolumn{4}{|c|}{ Massa fresca $(g)^{1,3}$} \\
\hline & \multirow{2}{*}{$\frac{\mathbf{N S}}{2,67}$} & \multirow{2}{*}{$\begin{array}{c}\mathbf{S} \\
1,00\end{array}$} & \multicolumn{2}{|c|}{ Média } & \multicolumn{2}{|c|}{ NS } & \multicolumn{2}{|c|}{$\mathbf{S}$} & \multirow{2}{*}{$\begin{array}{l}\text { Média } \\
45,00\end{array}$} & \multicolumn{2}{|c|}{ NS } & $\mathbf{S}$ & \multirow{2}{*}{$\begin{array}{l}\text { Média } \\
123,98\end{array}$} \\
\hline & & & 1,83 & $\mathrm{a}$ & 41,33 & a A & 48,67 & a B & & 50,54 & a A & 197,43 a B & \\
\hline Cama Frango & 2,33 & 1,33 & 1,83 & $\mathrm{a}$ & 44,17 & a A & 45,82 & a A & 44,99 & 38,77 & $\mathrm{~b} A$ & 96,36 b B & 67,56 \\
\hline Substrato & 3,67 & 1,33 & 2,50 & $\mathrm{a}$ & 38,00 & b A & 41,33 & b B & 39,66 & 27,05 & c A & 44,25 c B & 35,65 \\
\hline Média & $2,89 \mathrm{~A}$ & $1,22 \mathrm{~B}$ & & & 41,17 & & 45,27 & & & 38,79 & & 112,68 & \\
\hline CV $(\%)$ & & 10,47 & & & & & 3,79 & & & & & 2,96 & \\
\hline
\end{tabular}

${ }^{1}$ Média de três repetições. Médias seguidas por letras distintas minúsculas na coluna e maiúsculas na linha diferem entre si pelo teste de Tukey a 0,05.

${ }^{2}$ Dados originais. Para efeito de análise estatística, os dados foram transformados em raiz quadrada de $\mathrm{x}+0,5$.

${ }^{3}$ Dados originais. Para efeito de análise estatística, os dados foram transformados em logaritmo de x na base 10. 
Plantas com maior comprimento foram obtidas nos tratamentos solarizados e incorporados com torta de mamona e cama de frango. Entre os tratamentos não solarizados, a incorporação de matéria orgânica também resultou na produção de plantas com maior comprimento, estatisticamente diferente do comprimento das plantas do tratamento controle (substrato sem incorporação de matéria orgânica / não solarizado). Nos tratamentos incorporados com cama de frango, não houve diferença estatística para comprimento de plantas, entre o que foi solarizado e o que não foi solarizado (Tabela 16).

Todos os tratamentos aumentaram a massa fresca das plantas, quando comparados com o substrato sem incorporação de matéria orgânica e não solarizado. Aqueles que receberam solarização proporcionaram plantas com maior massa fresca que o respectivo tratamento sem solarização, havendo grande destaque para a incorporação de torta de mamona seguida de solarização, que resultou em plantas muito bem desenvolvidas, grandes e de excelente aspecto (Tabela 16, Figura 13).

Todos os tratamentos também elevaram a temperatura máxima do solo em relação à testemunha (Tabela 17). A elevação da temperatura máxima média do solo, na profundidade de $10 \mathrm{~cm}$, foi de $11,6^{\circ} \mathrm{C}$ e $3,9^{\circ} \mathrm{C}$ para os tratamentos incorporados com torta de mamona solarizados e não solarizados, respectivamente; de $7,8^{\circ} \mathrm{C}$ e $1,1^{\circ} \mathrm{C}$ para os tratamentos incorporados com cama de frango solarizados e não solarizados, respectivamente; e de $5,9^{\circ} \mathrm{C}$ para o substrato apenas solarizado, sem incorporação de matéria orgânica. A flutuação da temperatura diária do solo, durante todo o período de solarização, nos diferentes tratamentos, é apresentada no Apêndice 24.

Com respeito à concentração de gases avaliadas nos diversos tratamentos durante o período de solarização, observa-se que no segundo dia após a cobertura do solo com plástico, houve grande redução nos níveis de oxigênio $\left(\mathrm{O}_{2}\right)$ dos tratamentos solarizados, destacando-se aquele incorporado com torta de mamona, que atingiu $0,47 \%$ de $\mathrm{O}_{2}$ (Figura 12 - a). Nesses tratamentos, as concentrações de $\mathrm{O}_{2}$ aumentaram a partir do $16^{\circ}$ dia de solarização e atingiram valores similares, ao redor de $12 \%$ no $30^{\circ}$ dia. Uma maior anaerobiose ocorreu nos substratos solarizados com incorporação de matéria 
orgânica. Para os substratos não solarizados, não houve redução da concentração de $\mathrm{O}_{2}$, independente da incorporação de matéria orgânica (Figura 12 - b).

Tabela 17. Temperaturas máximas do solo registradas durante o período de solarização $(21 / 10 / 2004$ a 25/11/2004) para os diferentes tratamentos

\begin{tabular}{|c|c|c|c|c|c|}
\hline \multirow{2}{*}{ Tratamento $^{1}$} & \multicolumn{2}{|c|}{ Temp. máxima } & \multicolumn{3}{|c|}{$\mathbf{N}^{0}$ horas com temperatura } \\
\hline & Absoluta & Média & $\geq 37^{\circ} \mathrm{C}$ & $\geq 40^{\circ} \mathrm{C}$ & $\geq 48^{\circ} \mathrm{C}$ \\
\hline TMS & 52,2 & 41,6 & 177,5 & 105,5 & 15 \\
\hline CFS & 47,3 & 37,8 & 123 & 52,5 & 0 \\
\hline $\mathrm{SS}$ & 42,6 & 35,9 & 77 & 20,5 & 0 \\
\hline TMNS & 40,6 & 33,9 & 17 & 1,0 & 0 \\
\hline CFNS & 37,9 & 31,1 & 6 & 0 & 0 \\
\hline SNS & 35,5 & 30,0 & 0 & 0 & 0 \\
\hline
\end{tabular}

${ }^{1}$ TMS = incorporação de torta de mamona / solarizado; TMNS = incorporação de torta de mamona / não solarizado; CFS = incorporação de cama de frango / solarizado; CFNS = incorporação de cama de frango / não solarizado; $\mathrm{SS}$ = substrato sem incorporação de matéria orgânica / solarizado; SNS = substrato sem incorporação de matéria orgânica / não solarizado.

As concentrações de dióxido de carbono $\left(\mathrm{CO}_{2}\right)$ aumentaram nos tratamentos solarizados, principalmente no segundo dia de solarização e de forma mais marcante para o tratamento em que houve incorporação de torta de mamona, seguido daquele com incorporação de cama de frango e finalmente do substrato apenas solarizado. No $30^{\circ}$ dia esses tratamentos mostraram concentrações de $\mathrm{CO}_{2}$ semelhantes, em torno de $5 \%$ (Figura 12 - c). Nos tratamentos não solarizados, as concentrações de $\mathrm{CO}_{2}$ não sofreram elevação (Figura 12 - d). Os resultados obtidos para as concentrações de $\mathrm{O}_{2}$ e $\mathrm{CO}_{2}$ foram inversamente proporcionais, devido ao fato desses gases estarem presentes no solo em concentrações inversamente relacionadas (Souza, 2001). 

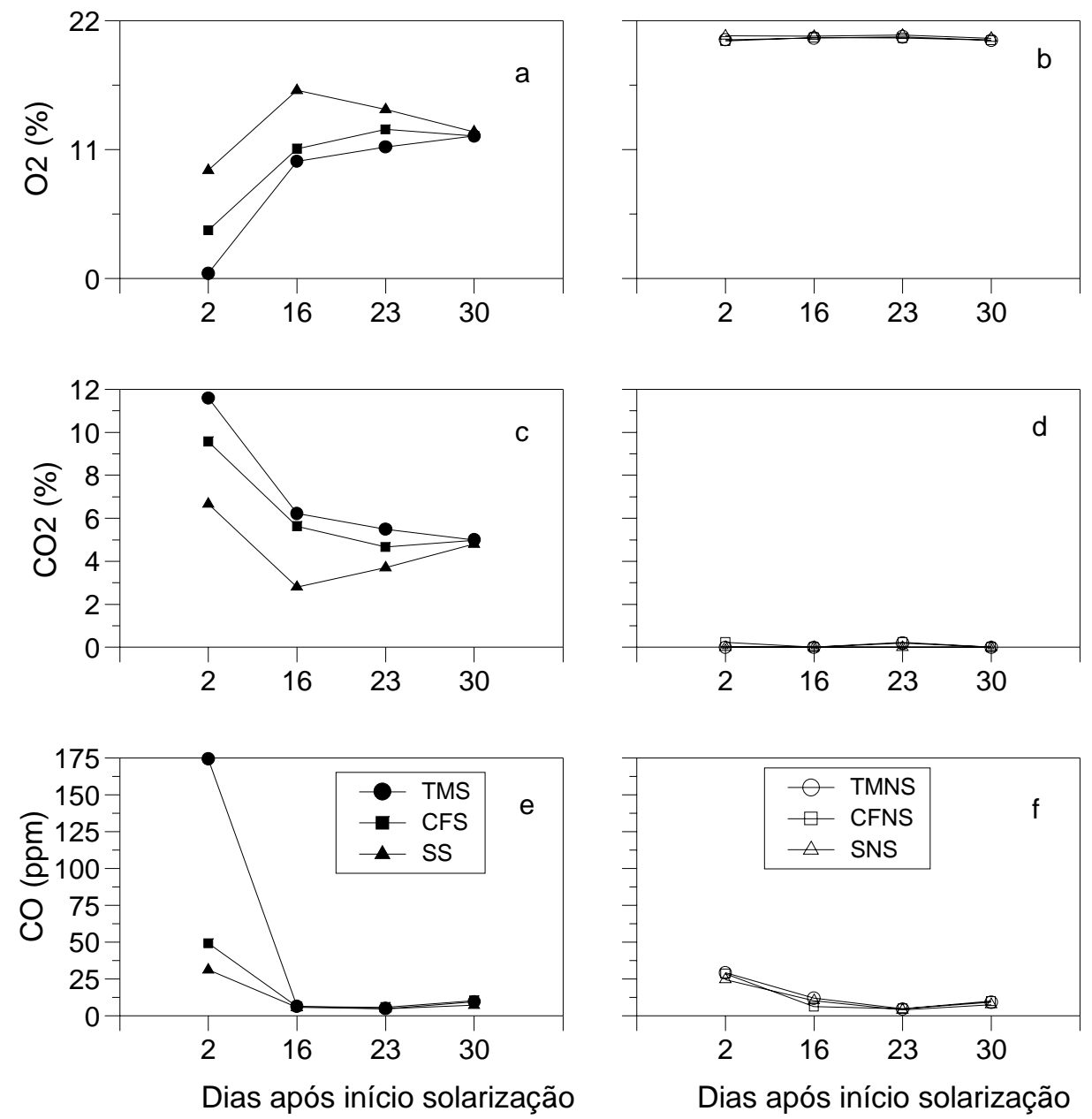

Figura 12 - Concentrações de gases no solo, registradas durante o período de solarização, na profundidade de $10 \mathrm{~cm}$. a) Oxigênio / tratamentos solarizados, b) Oxigênio / tratamentos não solarizados, c) Dióxido de carbono / tratamentos solarizados, d) Dióxido de carbono / tratamentos não solarizados, e) Monóxido de carbono / tratamentos solarizados e f) Monóxido de carbono / tratamentos não solarizados 


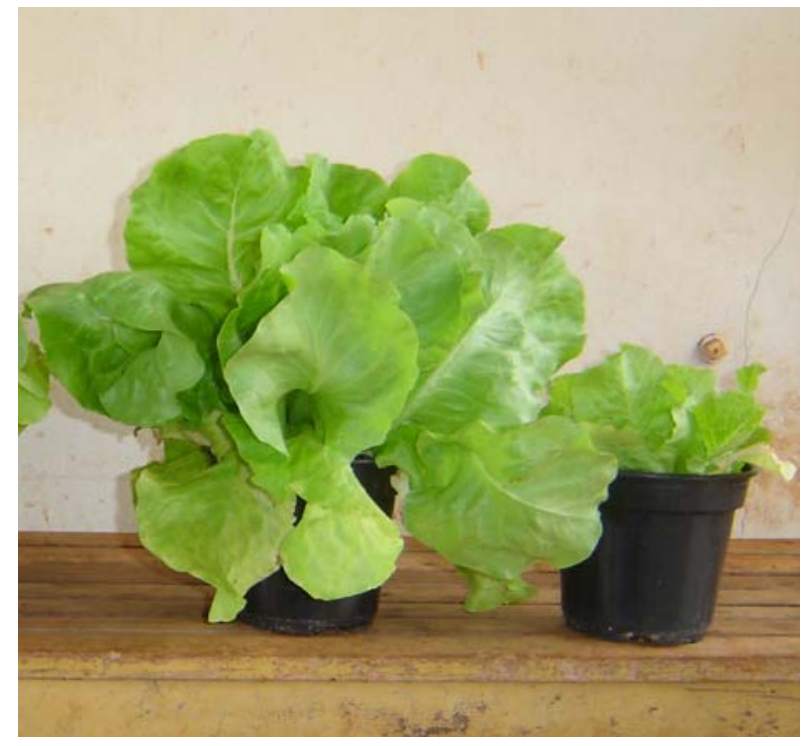

Figura 13 - Aspecto das plantas de alface nos seguintes tratamentos: substrato incorporado com torta de mamona / solarizado (esquerda) e substrato sem incorporação de matéria orgânica / não solarizado (direita)

A incorporação de torta de mamona seguida de solarização ocasionou um pico de elevação da concentração de monóxido de carbono $(\mathrm{CO})$ no solo no segundo dia de solarização, enquanto nos demais tratamentos solarizados houve apenas um pequeno acréscimo nos teores desse gás em relação aos tratamentos não solarizados. A partir do $16^{\circ}$ dia de solarização, as concentrações de $\mathrm{CO}$ nos tratamentos solarizados decresceram abruptamente e continuaram baixas até o $30^{\circ}$ dia (Figura 12 - e). Nos tratamentos não solarizados houve pequeno incremento nas concentrações de $\mathrm{CO}$ apenas na primeira avaliação, mas a partir do $16^{\circ}$ dia de solarização, esses teores mantiveram-se bastante baixos até o $30^{\circ}$ dia (Figura 12 - f).

A solarização do solo com e sem incorporação de matéria orgânica controlou eficientemente a podridão negra da raiz de alface. O tratamento de maior destaque foi aquele em que foi realizada a incorporação de 10 ton / ha de torta de mamona, seguida de solarização. Esse tratamento foi superior na redução da severidade da doença, 
proporcionou maior aumento no comprimento e na massa fresca das plantas (Tabela 16), ocasionou maior elevação da temperatura durante o período de solarização, apresentando a maior temperatura máxima do solo e o maior número de horas com temperaturas acima de $37^{\circ} \mathrm{C}$ (Tabela 17). Além disso, promoveu condições mais drásticas de anaerobiose e maior concentração de monóxido de carbono nos primeiros dias da solarização (Figura 12). Resultados similares foram obtidos por Souza (2001), que controlou eficientemente Sclerotium rolfsii através da incorporação de $0,8 \mathrm{Kg} / \mathrm{m}^{2}$ de torta de mamona imediatamente antes da solarização do solo. Apenas a solarização do solo, sem incorporação de matéria orgânica não foi efetiva na mortalidade do patógeno. O autor não encontrou notável elevação da temperatura do solo solarizado e incorporado com torta de mamona em relação ao solo apenas solarizado. Assim, sugeriu três hipóteses para explicar a eficiência do tratamento incorporado com torta de mamona e solarizado: a atuação de substâncias voláteis ainda não determinadas, responsáveis pela morte de S. rolfsii; a sensibilidade do fungo à condição de anaerobiose associada aos elevados níveis de monóxido de carbono registrados no solo na primeira semana de solarização; e a fermentação acelerada da torta de mamona, que promove um acréscimo na população de microrganismos que lisam os escleródios do patógeno.

Apesar do mecanismo de inativação de Thielaviopsis basicola não ter sido especificamente estudado no presente trabalho, os resultados obtidos permitem afirmar que as hipóteses acima, associadas às altas temperaturas do solo durante a solarização (Tabela 17, Apêndice 24), são perfeitamente adequadas para justificar o controle do patógeno pela solarização com a incorporação de torta de mamona. Esse tratamento foi o único que elevou a temperatura do solo acima de $48^{\circ} \mathrm{C}$, durante quinze horas (Tabela 17). Essas quinze horas foram registradas em apenas cinco dias, durante 2,5 horas no dia 14; 2 horas no dia 21; 2 horas no dia 22; 4 horas no dia 23 e 4,5 horas no dia 24 de novembro de 2004. Segundo Bollen (1969), a inativação térmica de T. basicola ocorre a $48^{\circ} \mathrm{C}$, com um tempo de exposição de trinta minutos.

De acordo com De Vay \& Katan (1991), é necessário um tempo de exposição entre duas e quatro semanas a temperaturas subletais (acima de $37^{\circ} \mathrm{C}$ ), para que ocorra a inativação da maioria dos fungos mesofílicos. Quando a temperatura é elevada a $47^{\circ} \mathrm{C}$, 
um período de exposição de 1 a 6 horas é suficiente para causar a morte dos propágulos. Apesar dos clamidósporos (estruturas de resistência) de T. basicola serem multicelulares e provavelmente possuírem maior número de mecanismos de reparação a injúrias causadas por estresses ambientais (De Vay \& Katan, 1991), Pullman et al. (1981) constataram atraso na germinação de clamidósporos de T. basicola quando expostos a temperaturas subletais. Esse atraso variou com a temperatura e o tempo de exposição, sendo maior em temperaturas entre 37 e $39^{\circ} \mathrm{C}$. Segundo os autores, ocorre um acúmulo gradual dos danos provocados pelo calor até o ponto em que o propágulo não é mais capaz de se recuperar. De Vay \& Katan (1991) preconizam que a exposição de um propágulo fúngico a temperaturas subletais, o torna mais sensível ao ataque de microrganismos antagonistas e também a fumigantes e outros defensivos químicos.

A solarização do substrato com incorporação de 10 ton / ha de cama de frango foi mais eficiente que apenas a solarização na redução da severidade da podridão negra da raiz de alface. Proporcionou também a produção de plantas com maiores comprimento e massa fresca (Tabela 16). A maior eficácia no controle do patógeno, deve-se, provavelmente, ao maior tempo de exposição a temperaturas subletais (Tabela 17) e à sensibilidade do patógeno às condições anaeróbias mais rigorosas nos primeiros dias de solarização (Figura 12 - a, c). Além disso, a amônia gerada durante a decomposição do esterco de frango é tóxica a microrganismos e nematóides fitopatogênicos (Gamliel et al., 2000; Riegel \& Noe, 2000), inclusive a T. basicola (Chun \& Lockwood, 1985). Uma mais alta atividade de microrganismos antagonistas também pode ter contribuído para o controle de T. basicola, devido à acelerada fermentação da cama de frango.

Gamliel \& Stapleton (1993) também controlaram eficientemente Pythium ultimum Trow em dois cultivos sucessivos de alface, através da solarização e da integração da solarização com incorporação de esterco de frango. As temperaturas do solo solarizado com incorporação do composto foram 2 a $3^{\circ} \mathrm{C}$ mais elevadas que as do solo apenas solarizado. Entretanto, nos dois tratamentos solarizados, ocorreu aumento na produtividade da cultura e intensiva colonização da rizosfera das plantas com Pseudomonas fluorescentes e Bacillus spp. 
A concentração de oxigênio na atmosfera do solo coberto com plástico, depende da difusão desse elemento a partir do solo adjacente não coberto, da difusão através do filme plástico e de seu consumo pela microflora do solo e em outros processos oxidativos (Blok et al., 2000). O rápido estabelecimento de condições anaeróbicas nas parcelas solarizadas, especialmente naquelas incorporadas com matéria orgânica, indica que houve elevada respiração microbiana logo nos primeiros dias de solarização. Após o $16^{\circ}$ dia de solarização, a redução dos teores de $\mathrm{CO}_{2}$ e o aumento nos níveis de $\mathrm{O}_{2}$, podem ser explicados pela redução da microbiota, ou seja, da respiração do solo, que ocorreu possivelmente pela associação entre a elevada concentração de $\mathrm{CO}_{2}$ nos primeiros dias de solarização e as altas temperaturas do solo (Tabela 17, Apêndice 24, Figura 12 - a, c) (Souza, 2001). O efeito supressivo do $\mathrm{CO}_{2}$, liberado durante a decomposição de materiais orgânicos, foi relatado por Bruehl (1986). O autor constatou que quanto maior a concentração de $\mathrm{CO}_{2}$ em restos de cultura de soja, menor foi a colonização do substrato por Rhizoctonia solani.

Os maiores comprimento e massa fresca das plantas de alface observados nos tratamentos solarizados, são devidos ao controle de T. basicola (Tabela 16) e à maior quantidade de nutrientes presentes nos substratos após a solarização (Apêndice 25). Segundo Katan (1980) a solarização promove a liberação de nutrientes no solo. Uma maior concentração de nutrientes, em solos solarizados em relação a solos não solarizados, também foi encontrada por Chen et al. (1991), Gamliel \& Stapleton (1993) e Sinigaglia et al. (2001). Além disso, as alterações biológicas em favor de populações de antagonistas, que ocorrem em solos solarizados, também favorecem o incremento no desenvolvimento de plantas (Chen et al., 1991).

A adoção da técnica da solarização para o controle de patógenos veiculados pelo solo tem sido restrita entre os produtores de alface. Esse fato deve-se principalmente à necessidade de gastos adicionais e à inutilização da área durante os meses mais quentes do ano, época em que essa hortaliça atinge elevados preços. Milan \& Shirota (2003) realizaram um estudo comparativo da viabilidade econômica da utilização da solarização e do cultivo convencional para o controle de fitopatógenos, plantas daninhas e algumas pragas em alface. Empregando a metodologia de análise 
custo / benefício, através da elaboração de um fluxo de caixa e cálculo de indicadores econômico-financeiros e de rentabilidade, concluíram que em um período de três anos, a produção de alface usando a solarização foi economicamente mais lucrativa que a produção convencional. Para taxas de descontos de 10, 15 e $20 \%$, o Valor Presente Líquido foi de respectivamente: $\mathrm{R} \$ 74.891,42$; $\mathrm{R} \$ 69.308,44$ e $\mathrm{R} \$ 64.416,32$ / ha para o plantio convencional; e R\$ 106.990,51; R\$ 99.335,27 e R\$ 92.620,00 / ha para o cultivo empregando a solarização.

A solarização do solo controlou eficientemente a podridão negra da raiz de alface e seu efeito foi potencializado pela incorporação de cama de frango e, especialmente, de torta de mamona. Dessa forma, se constitui numa interessante alternativa para a desinfestação química do solo, principalmente em pequenas propriedades ou cultivos protegidos, nos quais o patógeno já tenha se instalado. 


\section{CONCLUSÕES}

1 Em cultivos comerciais do interior do Estado de São Paulo, Thielaviopsis basicola ocorreu em alface dos tipos lisa, americana e crespa, chicória e rúcula.

2 A $21^{\circ} \mathrm{C}$, o isolado $\mathrm{L}_{1}$ de $T$. basicola foi mais agressivo a plântulas de alface que a $30^{\circ} \mathrm{C}$, ocasionando maiores severidade da doença e restrição do comprimento de plântulas.

3 Todos os isolados de T. basicola induziram necrose radicular e subdesenvolvimento de plântulas a 21 e $27^{\circ} \mathrm{C}$. $\mathrm{O}$ isolado $\mathrm{A}_{2}$ foi o mais agressivo. Os isolados foram mais agressivos a 27 que a $21^{\circ} \mathrm{C}$, com exceção de $\mathrm{L}_{1}$ e $\mathrm{L}_{2}$.

4 As cultivares de alface do tipo lisa foram suscetíveis a T. basicola e as do tipo crespa foram resistentes, exceto Verônica. Entre as cultivares do tipo americana, Invader, Classic e Lucy Brown foram suscetíveis, enquanto Warrior, Raider e Mohawk foram resistentes ao patógeno.

5 A resistência de alface a T. basicola não foi expressa no estágio de plântulas. Portanto, não houve correlação entre a reação de cultivares de alface ao patógeno em condições in vitro e in vivo.

6 De modo geral, o fungicida carbendazim foi o mais eficiente na inibição in vitro do crescimento micelial e da esporulação dos isolados $\mathrm{L}_{1}, \mathrm{~A}_{2}$ e $\mathrm{CH}$ de T. basicola. 
7 A aplicação dos fungicidas carbendazim, tiofanato metílico, cyproconazole, triadimenol, tebuconazole e da mistura hexaconazole+chlorothalonil, na forma de rega, controlou efetivamente a podridão negra da raiz de alface.

8 A solarização do solo, associada ou não à incorporação de cama de frango e de torta de mamona, controlou eficientemente T. basicola no cultivo de alface.

9 O efeito da solarização no controle de T. basicola foi potencializado pela incorporação no solo de cama de frango e, principalmente, de torta de mamona. 


\section{REFERÊNCIAS BIBLIOGRÁFICAS}

ABAWI, G.S. Black root rot. In: HALL, R. (Ed.). Compendium of bean diseases. St. Paul: APS Press, 1991. p.8-9.

ADAMS, P.B. Effect of soil temperature and soil amendments on Thielaviopsis root rot of sesame. Phytopathology, v.61, n.1, p.93-97, 1971.

BATEMAN, D.F.; DIMOCK, A.W. The influence of temperature on root rots of poinsettia caused by Thielaviopsis basicola, Rhizoctonia solani, and Pythium ultimum. Phytopathology, v.49, n.10, p.641-647, 1959.

BARNETT, H.L.; HUNTER, B.B. Illustrated genera of imperfect fungi. 4.ed. New York: Macmillan Publishing, 1987. 218 p.

BARROS, C.B.; PATRÍCIO, F.R.A.; LOPES, M.E.B.M.; FREITAS, S.S.; SINIGAGLIA, C.; MALAVOLTA, V.M.A.; TESSARIOLI NETO, J.; GHINI, R. Solarização do solo com filmes plásticos com e sem aditivo estabilizador de luz ultravioleta. Horticultura Brasileira, v.22, n.2, p.253-259, 2004.

BELTRÃO, N.E.M. Torta de mamona (Ricinus communis L.): fertilizante e alimento. Campina Grande: EMBRAPA ALGODÃO, 2003. 5p. (Comunicado Técnico, 171). 
BHATTI, M.A.; KRAFT, J.M. Effects of inoculum density and temperature on root rot and wilt of chickpea. Plant Disease, v.76, n.1, p.50-54, 1992a.

BHATTI, M.A.; KRAFT, J.M. Influence of soil moisture on root rot and wilt of chickpea. Plant Disease, v.76, n.12, p.1259-1262, 1992 b.

BOLLEN, G.J. The selective effect of heat treatment on the microflora of a greenhouse soil. Netherlands Journal of Plant Pathology, v.75, n.1/6, p. 157-163, 1969.

BLOK, W.J.; LAMERS, J.G.; TERMORSHUIZEN, A.J.; BOLLEN, G.J. Control of soilborne plant pathogens by incorporating fresh organic amendments followed by tarping. Phytopathology, v.90, n.3, p.253-259, 2000.

BRUEHL, G.W. Soil aeration. In: BRUEHL, G.W. Soilborne plant pathogens. New York: MacMillam, 1986. p.58-71.

CENTRAL DE ABASTECIMENTO DE CAMPINAS S.A. (CEASA-CAMPINAS). Cultura da alface.

http://www.ceasacampinas.com.br/pd01b.htm (02 mar. 2002).

CHEN, Y.; KATAN, J. Effect of solar heating of soils by transparent polyethylene mulching on their chemical properties. Soil Science, v.130, n.5, p.271-277, 1980.

CHEN, Y.; GAMLIEL, A.; STAPLETON, J.J.; AVIAD, T. Chemical, physical , and microbial changes related to plant growth in disinfested soils. In: KATAN, J.; De VAY, J.E. (Ed.). Soil Solarization. Boca Raton: CRC Press, 1991. cap.8, p.103129. 
CHUN, D.; LOCKWOOD, J.L. Reductions of Pythium ultimum, Thielaviopsis basicola and Macrophomina phaseolina populations in soil associated with ammonia generated from urea. Plant Disease, v.69, n.2, p.154-158, 1985.

CHUPP, C.; SHERF, A.F. Vegetables diseases and their control. New York: The Ronald Press, 1960. 693 p.

COHEN, Y.; LEVY, Y. Joint action of fungicides in mixtures: theory and practice. Phytoparasitica, v.18, n.2, p.159-169, 1990.

COPES, W.E.; HENDRIX, F.F. Influence of $\mathrm{NO}_{3} / \mathrm{NH}_{4}$ ratio, $\mathrm{N}, \mathrm{K}$, and $\mathrm{pH}$ on root rot of Viola $x$ wittrockiana caused by Thielaviopsis basicola. Plant Disease, v.80, n.8, p.879-884, 1996.

DAVIS, J.R.; SORENSEN, L.H. Influence of soil solarization at moderate temperatures on potato genotypes with differing resistance to Verticillium dahliae. Phytopathology, v.76, p.1021-1026, n. 10, 1986.

DAVIS, R.M. (Ed.); SUBBARAO, K.V.; RAID, R.N.; KURTZ, E.A. Compendium of lettuce diseases. St. Paul: The American Phytopathological Society, 1997. 79p.

De VAY, J.E.; KATAN, J. Mechanisms of pathogen control in solarized soils. In: KATAN, J.; De VAY, J.E. (Ed.). Soil Solarization. Boca Raton: CRC Press, 1991. cap.7, p.87-101.

EDGINGTON, L.V.; KHEW, K.L.; BARRON, G.L. Fungitoxic spectrum of benzimidazole compounds. Phytopathology, v. 61, n.1, p. 42-44, 1971.

ELAD, Y.; KATAN, J.; CHET, I. Physical, biological and chemical control integrated for soilbome diseases in potatoes. Phytopathology, v.70, n.5, p. 418-422, 1980. 
FERREIRA, A.A. Efeito da solarização no controle da podridão de esclerotínia (Sclerotinia sclerotiorum (Lib.) de Bary) em alface americana (Lactuca sativa L.). Lavras, 2000. 60p. Dissertação (M.S.) - Universidade Federal de Lavras.

FIGUEIREDO, M.B. Estudos sobre a aplicação do método de Castellani para conservação de fungos patógenos em plantas. O Biológico, v.33, p. 9-13, 1967.

GAMLIEL, A.; KATAN, J. Involvement of fluorescent Pseudomonas and other microorganisms in increased growth response of plants in solarized soils. Phytopathology, v.81, n.5, p. 494-502, 1991.

GAMLIEL, A.; STAPLETON, J.J. Effect of chicken compost or ammonium phosphate and solarization on pathogen control, rhizosphere microorganisms, and lettuce growth. Plant Disease, v.77, n.9, p.886-891, 1993.

GAMLIEL, A.; KATAN, J.; CHEN, Y.; GRINSTEIN, A. Solarization for the reclamation of container media. Acta Horticulturae, v.255, p. 181-188, 1989.

GAMLIEL, A.; AUSTERWEIL, M.; KRITZMAN, G. Non-chemical approach to soilborne pest management - organic amendments. Crop Protection, v.19, n. 8/10, p.847-853, 2000.

GAYED, S.K. Effect of benomyl on black root rot of tobacco caused by Thielaviopsis basicola. Canadian Plant Disease Survey, v.49, p. 70-74, 1969.

GHINI, R. Desinfestação do solo com o uso de energia solar: solarização e coletor solar. Jaguariúna: EMBRAPA-CNPMA, 1997. 29 p. (Circular Técnica, 1). 
GRAHAM, J.H.; TIMMER, N.H. Peat-based media as a source of Thielaviopsis basicola causing black root rot on citrus seedlings. Plant Disease, v. 75, n.12, p.1246-1249, 1991.

HARTILL, W.F.T.; CAMPBELL, J.M. Fungicides to control black root rot of tobacco. Plant Disease Reporter, v. 56, n.8, p.708-711, 1972.

HOOD, M.E.; SHEW, H.D. Pathogenesis of Thielaviopsis basicola on a susceptible and a resistant cultivar of burley tobacco. Phytopathology, v.86, n.1, p.38-44, 1996.

HOLTZ, B.A.; WEINHOLD, A.R. Thielaviopsis basicola in San Joaquin Valley soils and the relationship between inoculum density and disease severity of cotton seedlings. Plant Disease, v.78, n.10, p.986-990, 1994.

HSI, D.C.H. Relationship between crop sequences and several diseases of Valencia peanuts. Phytopathology, v.57, n.5, p.461, 1967. /Resumo/

HSI, D.C.H.; ORTIZ JÚNIOR, M. Suppression of Thielaviopsis basicola by two fungicides applied to sandy loam soils in New Mexico. Plant Disease, v.64, n.11, p.1011-1012, 1980.

HUBER, D.M.; WATSON, R.D. Nitrogen form and plant disease. Annual Review of Phytopathology, v.12, p.139-165, 1974.

INSTITUTO BRASILEIRO DE GEOGRAFIA E ESTATÍSTICA (IBGE). Censo Agropecuário: Brasil, 1996.

http://www.sidra.ibge.gov.br/bda/tabela/protabl.asp?z=t\&o=l (08 mar. 2002).

JOHNSON, S.B.; BERGER, R.D. On the status of statistics in Phytopathology. Phytopathology, v.72, n.8, p.1014-1015, 1982. 
KATAN, J. Solar pasteurization on soils for disease control: status and prospects. Plant Disease, v.64, n.5, p. 450-454, 1980.

KATAN, J. Solar heating (solarization) of soil for control of soilborne pest. Annual Review of Phytopathology, v.19, p. 211-236, 1981.

LEE, F.N. Effect of soil solarization with clear plastic and shallow flood on the survival of Rhizoctonia solani sclerotia. Phytopathology, v.75, n.11, p. 1291, 1985. /Resumo/

LEFÈVRE, A.F.V.; SOUZA, N.L. Efeitos da solarização sobre algumas variáveis do solo. Summa Phytopathologica,v.19, n.2, p.113-118, 1993.

LLOYD, A.B.; LOCKWOOD, J.L. Precautions in isolating Thielaviopsis basicola with carrot discs. Phytopathological Notes, v.52, p.1314-1315, 1962.

LLOYD, A.B.; LOCKWOOD, J.L. Effect of soil temperature, host variety, and fungus strain on Thielaviopsis root rot of peas. Phytopathology, v.53, n.3, p.329-331, 1963.

LOPES, C.A.; QUEZADO-DUVAL, A.M. Doenças da alface. Brasília: EMBRAPA HORTALIÇAS, 1998. 18p. (Circular Técnica, 14).

MANNING, E.J.; CAMPBELL, E.J.; PAPIA, P.M.; HUGHES, P.A. Effectiveness of benomyl soil drenches for control of Thielaviopsis basicola root rot of poinsettia. Plant Disease Reporter, v.54, n.4, p.328-330, 1970. 
MARCOS FILHO, J.; CICERO, S.M.; TOLEDO, F.F. Teste de germinação. In: MARCOS FILHO, J.; CICERO, S.M.; TOLEDO, F.F. Manual de análise de sementes. Piracicaba: s. ed., 1985. cap. 5, p. 35-60.

MATHRE, D.E.; RAVENSCROFT, A.V.; GARBER, R.H. The role of Thielaviopsis basicola as a primary cause of yield reduction of cotton in California. Phytopathology, v.56, n.11, p.1213-1216, 1966.

MAUK, P.A.; HINE, R.B. Infection, colonization of Gossypium hirsutum and G. barbadense, and development of black root rot caused by Thielaviopsis basicola. Phytopathology, v.78, n.12, p.1662-1667, 1988.

MEYER, J.R.; SHEW, H.D. Development of black root rot on burley tobacco as influenced by inoculum density of Thielaviopsis basicola, host resistance, and soil chemistry. Plant Disease, v.75, n.6, p.601-605, 1991.

MEYER, J.R.; SHEW, H.D.; HARRISON, U.J. Inhibition of germination and growth of Thielaviopsis basicola by aluminum. Phytopathology, v.84, n.6, p.598-602, 1994.

MILAN, P.; SHIROTA, R. Análise econômica e financeira da solarização na cultura da alface. In: SIMPÓSIO INTERNACIONAL DE INICIAÇÃO CIENTÍFICA DA UNIVERSIDADE DE SÃO PAULO, 11., Piracicaba, 2003. Resumos. São Paulo: EDUSP, 2003. p.210.

NAG RAJ, T.R.; KENDRICK, B. A monograph of Chalara and allied genera. Ontario: Wilfrid Laurier University Press, 1975. 200p. 
NUNES, M.E.T. Solarização do solo e seleção de microrganismos antagônicos para o controle de Sclerotium cepivorum Berk., agente causal da podridão branca da cebola (Allium cepa L.). Piracicaba, 1992. 75 p. Dissertação (Mestrado) - Escola Superior de Agricultura “Luiz de Queiroz”, Universidade de São Paulo.

O'BRIEN, R.G.; DAVIS, R.D. Lettuce black root rot -a disease caused by Chalara elegans. Australasian Plant Pathology, v.23, n.3, p.106-111, 1994.

O'BRIEN, R.G.; DAVIS, R.D. Black root rot of lettuce - dpi note. http://www.dpi.qld.gov.au/horticulture/4759.html (22 jan. 2002).

OSMAN, A.R.; SAHAB, A.F. Control of Rhizoctonia solani by soil solarization. Acta Horticulturae, v.152, p. 245-251, 1984.

PAPAVIZAS, G.C.; LEWIS, J.A. Effect of cottonseed treatment with systemic fungicides on seedling disease. Plant Disease Reporter, v. 61, n.7, p.538-542, 1977.

PAPAVIZAS, G.C.; LEWIS, J.A.; RUSSELL, H. Chemical control of black root rot of bean and tobacco caused by Thielaviopsis basicola. Plant Disease Reporter, v. 56, n.1, p.15-19, 1972.

PAVAN, M.A.; KUROSAWA, C. Doenças da alface (Lactuca sativa L.). In: KIMATI, H.; AMORIM, L.; BERGAMIN FILHO, A.; CAMARGO, L.E.A.; REZENDE, J.A.M. (Ed.). Manual de Fitopatologia. v.2: Doenças das plantas cultivadas. 3.ed. São Paulo: Editora Agronômica Ceres, 1997. cap.4, p.18-25.

PRINSLOO, G.C.; DE VILLIERS, D.A.; DE BRUIN, D.J. Activity of triadimenol and flusilazol against Thielaviopsis basicola in tobacco. Phytophylactica, v.21, n.1, p.83-84, 1989. 
PRINSLOO, G.C.; BAARD, S.W.; FERREIRA, J.F. Organisms associated with black root rot of chicory in South Africa. Phytophylactica, v.23, n.1, p.59-67, 1991.

PULLMAN, G.S.; De VAY, J.E.; GARBER, R.H.; WEINHOLD, A.R. Soil solarization: Effects on verticillium wilt of cotton and soilborne population of Verticillium dahliae, Pythium spp., Rhizoctonia solani and Thielaviopsis basicola. Phytopathology, v.71, n.9, p. 954-959, 1981.

PUNJA, Z.K.; CHITTARANJAN, S. Prevalence and inoculum density of Chalara elegans in soils in the Fraser Valley of British Columbia. Canadian Journal of Plant Pathology, v.16, n.1, p.21-24, 1994.

RAABE, R.D.; HURLIMANN, J.H. Control of Thielaviopsis basicola root rot of poinsettia with benomyl and thiabendazole. Plant Disease Reporter, v. 55, n. 3, p.238-240, 1971.

RIEGEL, C.; NOE, J. Chicken litter soil amendment effects on soilborne microbes and Meloidogyne incognita on cotton. Plant Disease, v.84, n.12, p.1275-1281, 2000.

ROTHROCK, C.S. Influence of soil temperature, water, and texture on Thielaviopsis basicola and black root rot of cotton. Phytopathology, v.82, n.10, p.1202-1206, 1992.

SAENGER, H.L. Control of Thielaviopsis basicola root rot of tobacco with benomyl fungicide drenches. Plant Disease Reporter, v. 54, n.2, p.136-140, 1970.

SALA, F.C.; COSTA, C.P.; TEIXEIRA-YAÑEZ, L.D.D.; BLAT, S.F. Herança da reação de alface a murchadeira (Thielaviopsis basicola) (compact disc). Horticultura Brasileira, v.22, n.2, supl. jul. 2004a. 
SALA, F.C.; COSTA, C.P.; TEIXEIRA-YAÑEZ, L.D.D.; BLAT, S.F. Seleção de variantes resistentes a Thielaviopsis basicola na alface Lucy Brown (compact disc). Horticultura Brasileira, v.22, n.2, supl. jul. 2004b.

SCHOENMAKER, I.A.S. Solarização do solo associada à incorporação de matérias orgânicas para o controle de Pyhtium spp. Piracicaba, 2001. 50p. Dissertação (Mestrado) - Escola Superior de Agricultura "Luiz de Queiroz", Universidade de São Paulo.

SHEW, H.D.; MEYER, J.R. Thielaviopsis. In: SINGLETON, L.L.; MIHAIL, J.D.; RUSH, C.M. (Ed.). Methods for research on soilborne phytopathogenic fungi. St. Paul: APS Press, 1992. p.171-174.

SILVA, A.M.S.; AKIBA, F.; CARVALHO, A.O.; RIBEIRO, R.L.D., ARAÚJO, J.S.P. Podridão negra de raízes de quiabeiro e alface incitada por Thielaviopsis sp. Fitopatologia Brasileira, v.24, supl. p.328, 1999. /Resumo/

SINIGAGLIA, C.; PATRÍCIO, F.R.A.; GHINI, R.; MALAVOLTA, V.M.A.; TESSARIOLI, J.; FREITAS, S.S. Controle de Sclerotinia minor, Rhizoctonia solani e plantas daninhas em alface pela solarização do solo e sua integração com controle químico. Summa Phytopathologica, v.27, n.2, p. 229-235, 2001.

SOUZA, N.L. Solarização do solo. Summa Phytopathologica, v.20, n.1, p. 3-15, 1994.

SOUZA, N.L. Sobrevivência de Fusarium oxysporum f. sp. lycopersici e Sclerotium rolfsii em solo solarizado incorporado com matéria orgânica. Piracicaba, 2001. 46p. Tese (Livre-Docência) - Escola Superior de Agricultura "Luiz de Queiroz", Universidade de São Paulo. 
SOUZA, N.L.; LEFÈVRE, A.F.V. Efeito da solarização do solo sobre a cultura do feijoeiro e populações de micorrizas e nematóides. Fitopatologia Brasileira, v.15, n.2, p.148, 1990. /Resumo/

STANGHELLINI, M.E.; KRONLAND, W.C. Yield loss in hydroponically grown lettuce attributed to subclinical infection of feeder rootlets by Pythium dissotocum. Plant Disease, v.70, n.11, p.1053-1056, 1986.

STAPLETON, J.J.; De VAY, J.E. Effect of soil solarization on populations of selected soilbome microrganisms and growth of deciduous fruit tree seedlings. Phytopathology, v.72, n.3, p. 323-326, 1982.

STAPLETON, J.J.; De VAY, J.E. Thermal components of soil solarization as related to changes in soil and rot microflora and increased plant growth response. Phytopathology, v.74, n.3, p. 255-259, 1984.

STOVER, R.H. Physiological specialization and mutations in Thielaviopsis basicola. Phytopathology, v.41, n.1, p. 34, 1951. /Resumo/

TABACHNIK, M.; De VAY, J.E.; GARBER, R.H.; WAKEMAN, R.J. Influence of soil inoculum concentrations on host range and disease reactions caused by isolates of Thielaviopsis basicola and comparison of soil assay methods. Phytopathology, v.69, n.9, p.974-977, 1979.

TEIXEIRA-YAÑEZ, L.D.D.; SALA, F.C.; COSTA, C.P.; KIMATI, H. Da raiz às folhas. Cultivar HF, v.4, n. 20, p. 6-7, 2003.

TOSI, L.; ZAZZERINI, A. Evaluation of chemicals against Thielaviopsis basicola on tobacco in vitro and in soil. Petria, v.2, n.1, p.19-27, 1992. 
TREBILCO, E.; HOWELL, J.; FORSBERG, L.; BODMAN, K. Beware of Chalara elegans black root rot.

http://www.ngia.com.au/np/99_13/99_13.htm1 (30 jan. 2002).

TSAO, P.H.; Van GUNDY, S.D. Thielaviopsis basicola as a citrus root pathogen. Phytopathology, v.52, n.8, p.781-786, 1962.

YARWOOD, C.E. Isolation of Thielaviopsis basicola from soil by means of carrot disks. Mycologia, v..38, p.346-348, 1946.

WILKINSON, C.A.; RUFTY, R.C.; SHEW, H.D. Inheritance of partial resistance to black root rot in burley tobacco. Plant Disease, v.75, n.9, p.889-892, 1991. 


\section{APÊNDICES}


APÊNDICE 1. Resumo da análise de variância para comparação entre cultivares, do parâmetro nota, no teste de patogenicidade in vitro do isolado $\mathrm{L}_{1}$ a várias cultivares de alface. Piracicaba, 2003

\begin{tabular}{crcccc}
\hline & & \multicolumn{2}{c}{$\mathbf{2 1}^{\mathbf{0}} \mathbf{C}$} & \multicolumn{2}{c}{$\mathbf{3 0}^{\mathbf{0}} \mathbf{C}$} \\
Causas da Variação & GL & QM & F & QM & F \\
\hline Cultivar & 13 & 0,116450 & $71,81^{* *}$ & 0,407364 & $104,92^{* *}$ \\
Resíduo & 42 & 0,001621 & & 0,003882 & \\
Total & 55 & & & & \\
\hline
\end{tabular}

**Significativo ao nível de significância $\alpha=0,01$.

APÊNDICE 2. Resumo da análise de variância para comparação entre cultivar, inóculo e sua interação, do parâmetro comprimento da plântula, no teste de patogenicidade in vitro do isolado $L_{1}$ a várias cultivares de alface. Piracicaba, 2003

\begin{tabular}{|c|c|c|c|c|c|}
\hline \multirow[b]{2}{*}{ Causas da Variação } & \multirow[b]{2}{*}{$\mathbf{G L}$} & \multicolumn{2}{|c|}{$21^{\circ} \mathrm{C}$} & \multicolumn{2}{|c|}{$30^{\circ} \mathrm{C}$} \\
\hline & & QM & $\mathbf{F}$ & QM & $\mathbf{F}$ \\
\hline Cultivar & 13 & 0,138226 & $36,26^{* *}$ & 0,034267 & $10,63 * *$ \\
\hline Inóculo & 1 & 10,684588 & $2803,03 * *$ & 3,964917 & $1229,38 * *$ \\
\hline Cultivar x Inóculo & 13 & 0,049844 & $13,08 * *$ & 0,014778 & $4,58 * *$ \\
\hline Resíduo & 84 & 0,003811 & & 0,003225 & \\
\hline Total & 111 & & & & \\
\hline
\end{tabular}

**Significativo ao nível de significância $\alpha=0,01$. 

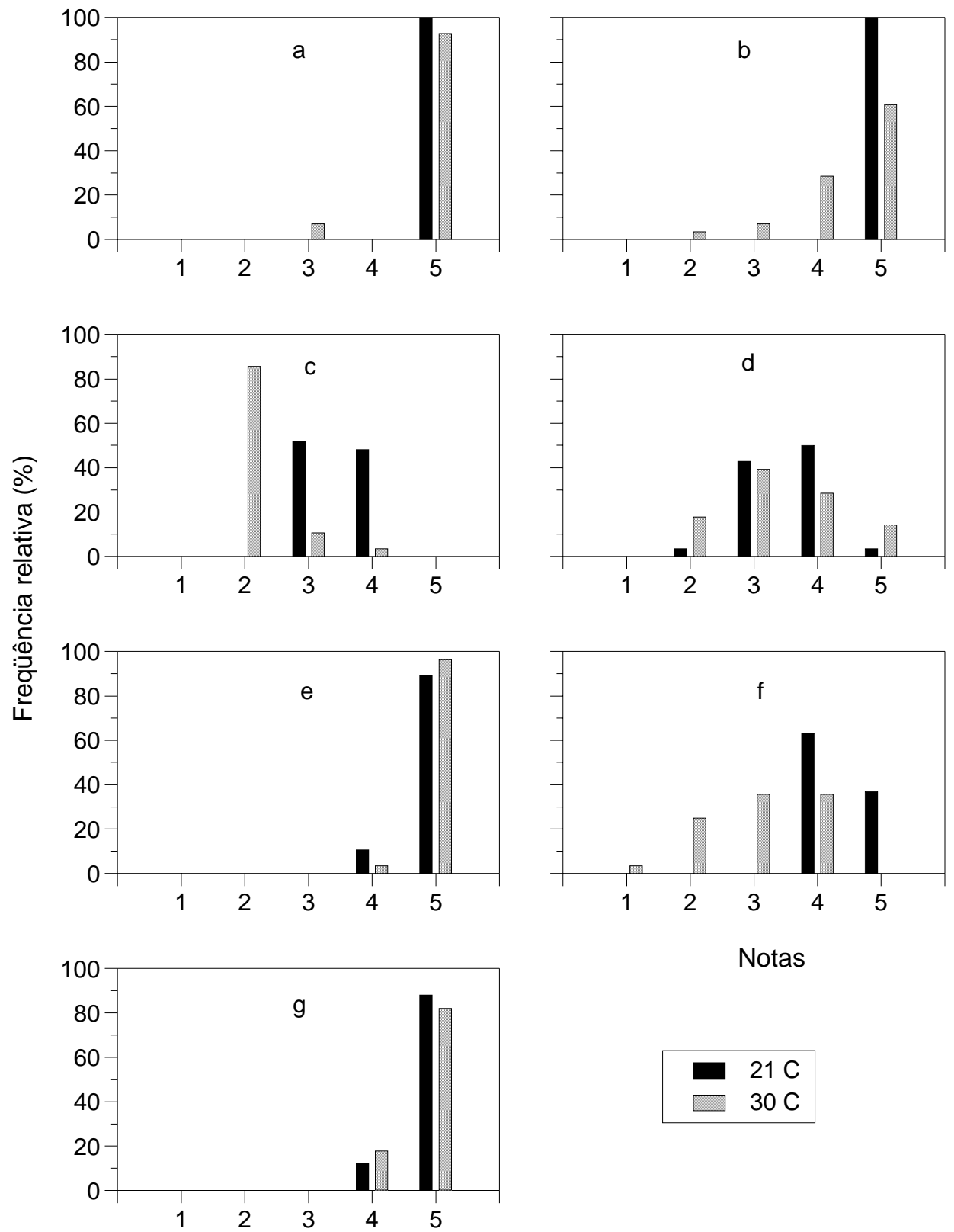

Notas

Notas

APÊNDICE 3 - Severidade da podridão negra da raiz, ocasionada pelo isolado $L_{1}$, em placa de Petri a 21 e $30^{\circ} \mathrm{C}$, nas cultivares de alface do tipo americana. a) Lucy Brown, b) Invader, c) Mohawk, d) Raider, e) Classic, f) Warrior e g)Tainá 

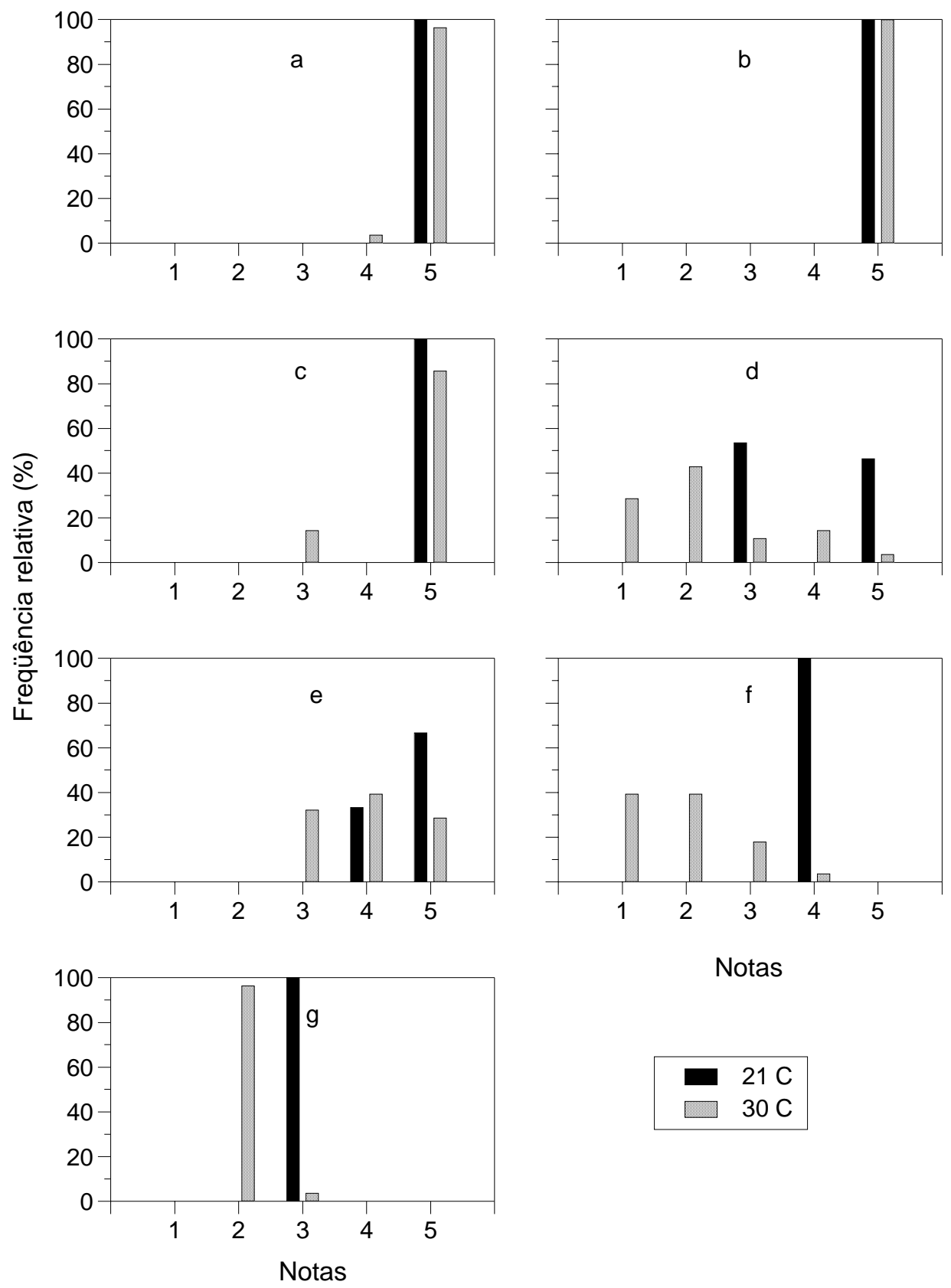

Notas

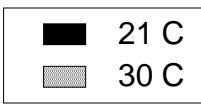

APÊNDICE 4 - Severidade da podridão negra da raiz, ocasionada pelo isolado $L_{1}$, em placa de Petri a 21 e $30^{\circ} \mathrm{C}$, nas cultivares de alface dos tipos lisa e crespa. a) Elisa, b) Regina, c) Luisa, d) Vera, e) Verônica, f) Locarno e g) New Red Fire 
APÊNDICE 5. Resumo da análise de variância para comparação entre isolados, do parâmetro nota, no teste de patogenicidade in vitro dos isolados de Thielaviopsis basicola. Piracicaba, 2003

\begin{tabular}{|c|c|c|c|c|c|}
\hline \multirow[b]{2}{*}{ Causas da Variação } & \multirow[b]{2}{*}{ GL } & \multicolumn{2}{|c|}{$21^{\circ} \mathrm{C}$} & \multicolumn{2}{|c|}{$27^{\circ} \mathrm{C}$} \\
\hline & & QM & $\mathbf{F}$ & QM & $\mathbf{F}$ \\
\hline Isolado & 14 & 0,416685 & $152,53 * *$ & 0,485501 & $172,15^{* *}$ \\
\hline Resíduo & 45 & 0,002731 & & 0,002820 & \\
\hline Total & 59 & & & & \\
\hline
\end{tabular}

**Significativo ao nível de significância $\alpha=0,01$

APÊNDICE 6. Resumo da análise de variância para comparação entre isolados, do parâmetro comprimento da plântula, no teste de patogenicidade in vitro dos isolados de Thielaviopsis basicola. Piracicaba, 2003

\begin{tabular}{cccccc}
\hline Causas da Variação & GL & QM & F & QM & F \\
\hline Isolado & 14 & 0,154112 & $90,93^{* *}$ & 0,128161 & $60,59^{* *}$ \\
Resíduo & 45 & 0,001694 & & 0,002115 & \\
Total & 59 & & & & \\
\end{tabular}

**Significativo ao nível de significância $\alpha=0,01$. 

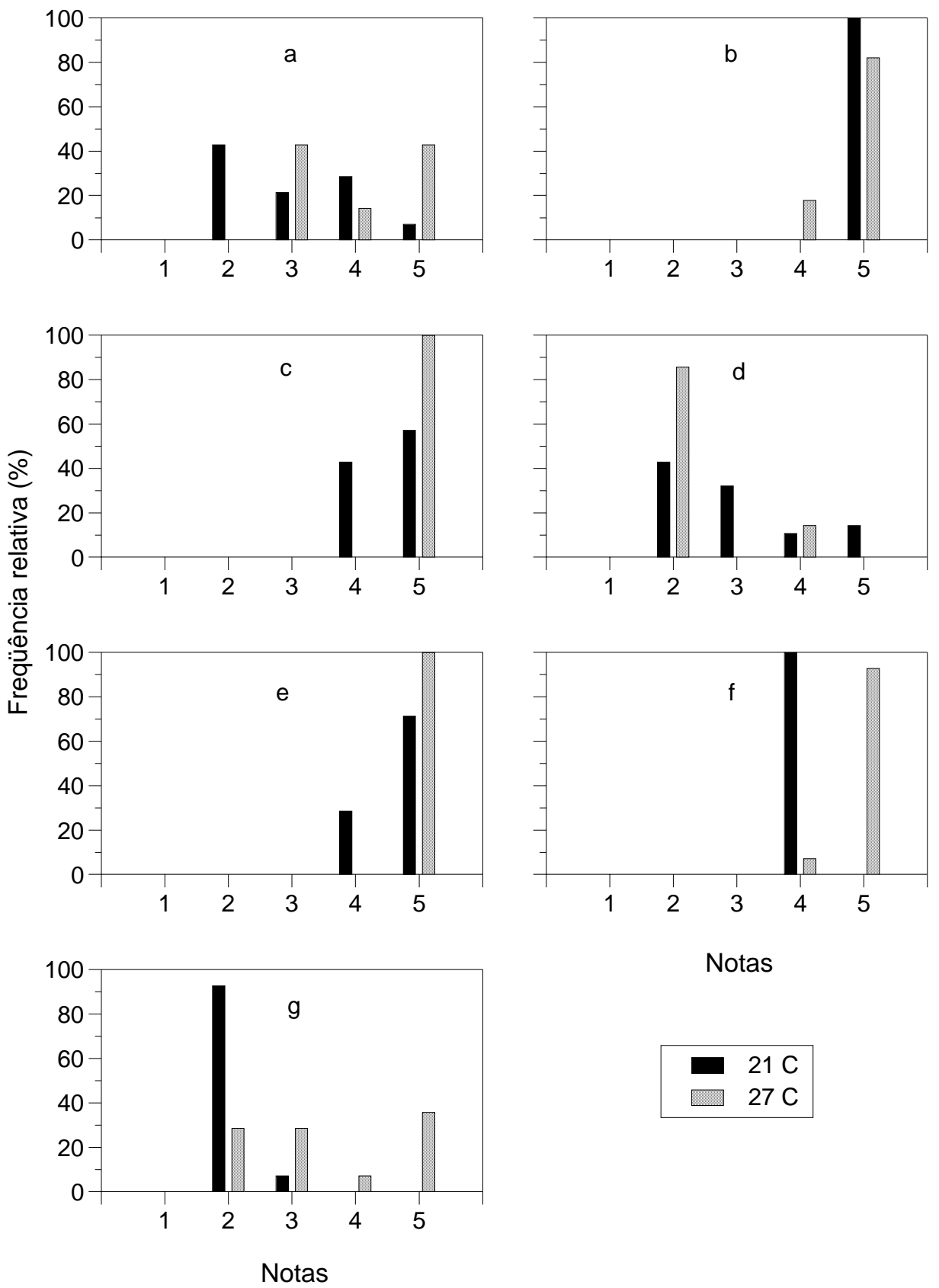

Notas

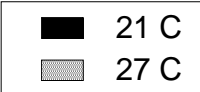

APÊNDICE 7 - Severidade da podridão negra da raiz, na cultivar de alface Elisa, em placa de Petri a 21 e $27^{\circ} \mathrm{C}$, incitada pelos isolados: a) $\mathrm{A}_{1}$, b) $\mathrm{A}_{2}$, c) $\mathrm{A}_{3}$, d) $\mathrm{A}_{4}$, e) $\mathrm{A}_{5}$, f) $\mathrm{C}_{1}$ e g) $\mathrm{CH}$ 

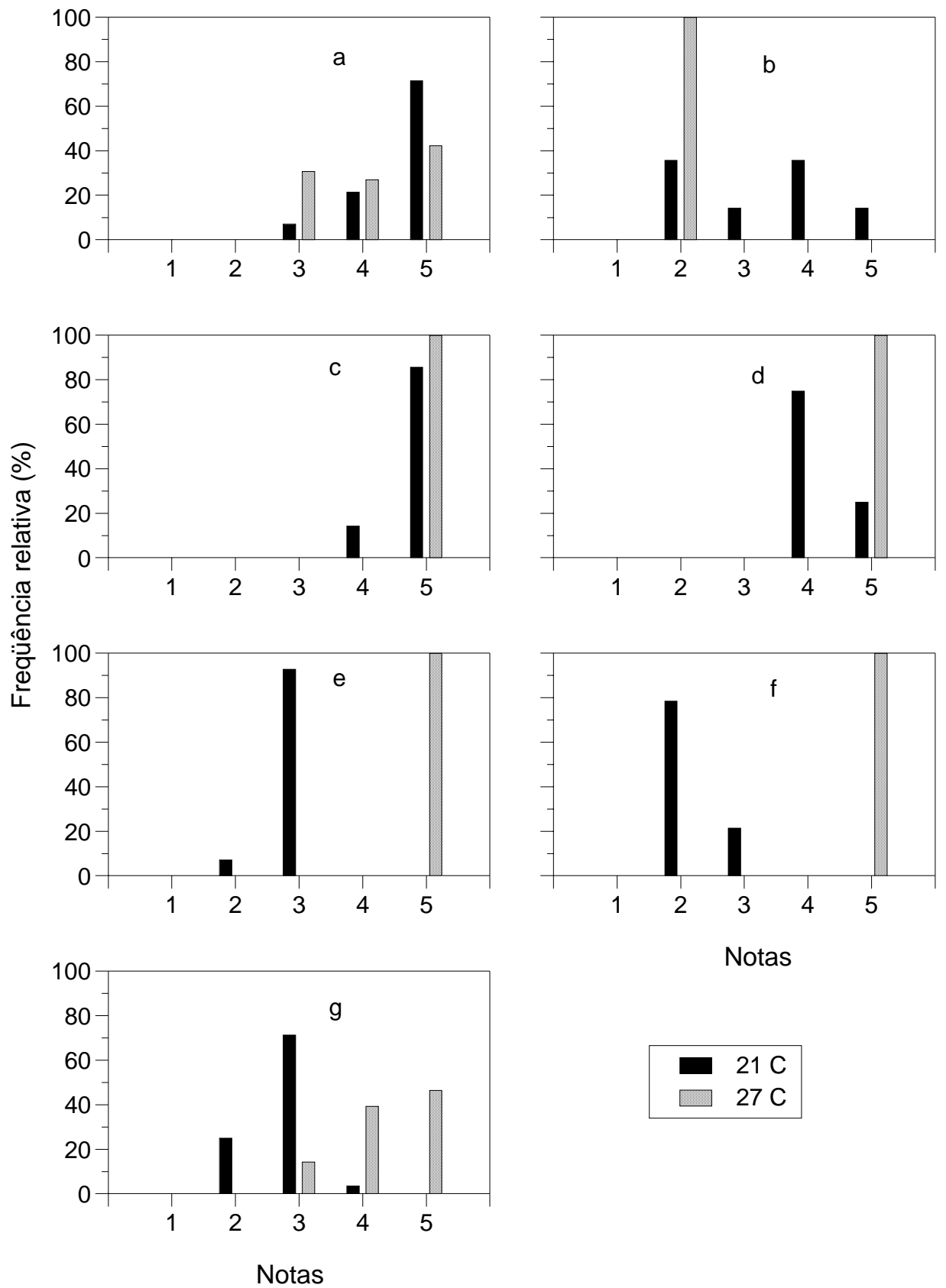

Notas

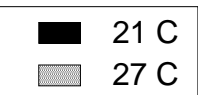

APÊNDICE 8 - Severidade da podridão negra da raiz, na cultivar de alface Elisa, em placa de Petri a 21 e $27^{\circ} \mathrm{C}$, incitada pelos isolados: a) $\mathrm{L}_{1}$, b) $\mathrm{L}_{2}$, c) $\mathrm{L}_{3}$, d) $L_{4}$, e) $L_{5}$, f) $R_{1}$ e g) $R_{2}$ 
APÊNDICE 9. Resumo da análise de variância para comparação entre cultivares, do parâmetro nota, no ensaio de reação varietal ao isolado $L_{1}$ de Thielaviopsis basicola. Piracicaba, 2003

\begin{tabular}{cccc}
\hline Causas da Variação & GL & QM & F \\
\hline Cultivar & 12 & 0,489412 & $28,07^{* *}$ \\
Resíduo & 39 & 0,017437 & \\
Total & 51 & & \\
\hline
\end{tabular}

**Significativo ao nível de significância $\alpha=0,01$.

APÊNDICE 10. Resumo da análise de variância para comparação entre cultivar, inóculo e sua interação, do parâmetro comprimento da muda, no ensaio de reação varietal ao isolado $\mathrm{L}_{1}$ de Thielaviopsis basicola. Piracicaba, 2003

\begin{tabular}{cccc}
\hline Causas da Variação & GL & QM & F \\
\hline Cultivar & 12 & 10,505737 & $6,33^{* *}$ \\
Inóculo & 1 & 26,200384 & $15,79^{* *}$ \\
Cultivar x Inóculo & 12 & 4,416634 & $2,66^{* *}$ \\
Resíduo & 78 & 1,659487 & \\
Total & 103 & & \\
\hline
\end{tabular}

**Significativo ao nível de significância $\alpha=0,01$. 

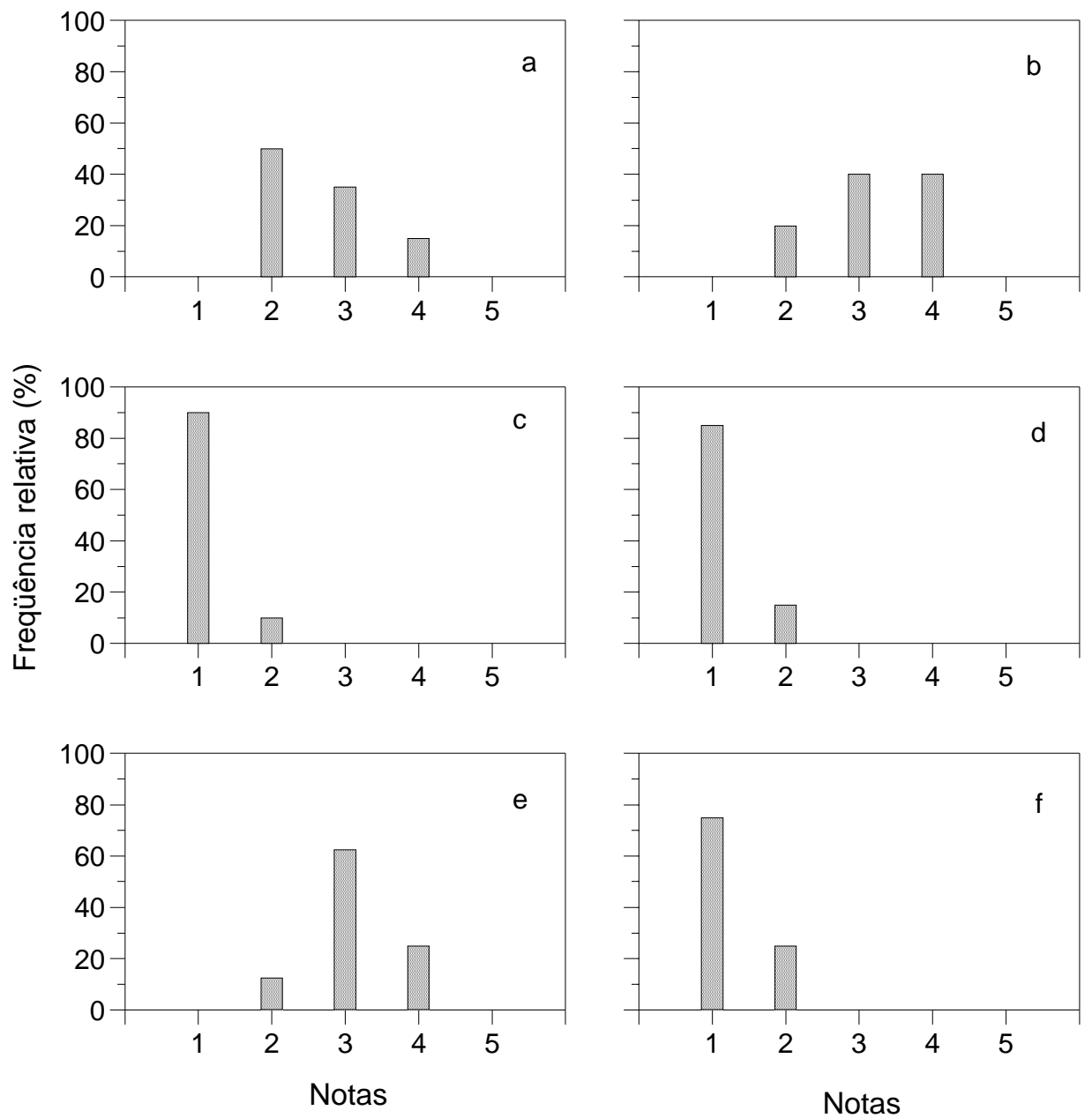

APÊNDICE 11 - Severidade da podridão negra da raiz, ocasionada pelo isolado $\mathrm{L}_{1}$, em casa-de-vegetação, nas cultivares de alface do tipo americana. a) Lucy Brown, b) Invader, c) Mohawk, d) Raider, e) Classic e f) Warrior 

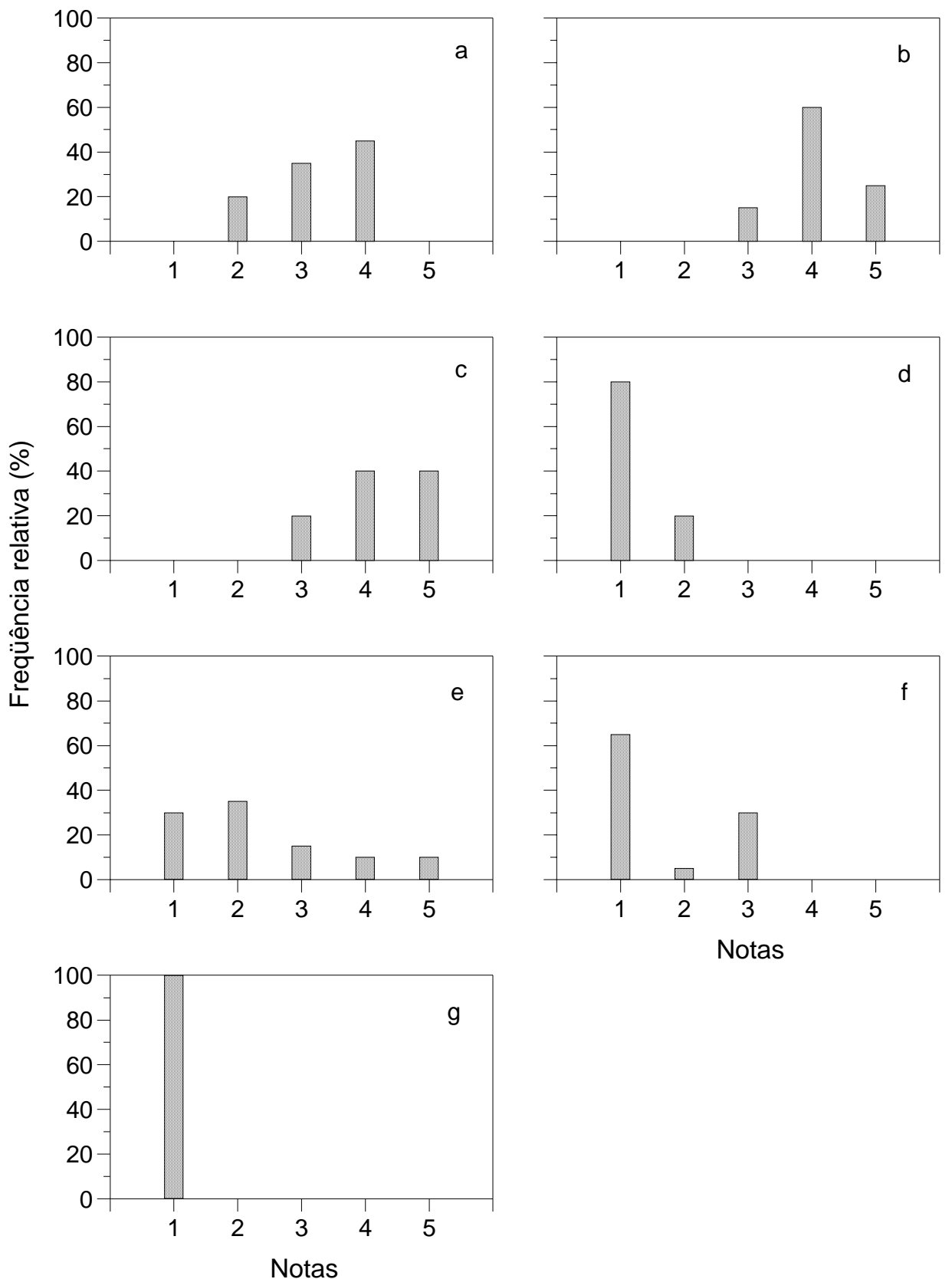

APÊNDICE 12 - Severidade da podridão negra da raiz, ocasionada pelo isolado $L_{1}$, em casa-de-vegetação, nas cultivares de alface dos tipos lisa e crespa. a) Elisa, b) Regina, c) Luisa, d) Vera, e) Verônica, f) Locarno e g) New Red Fire 
APÊNDICE 13. Resumo da análise de variância para comparação entre cultivar, inóculo e sua interação, do parâmetro nota, no ensaio de reação varietal aos isolados $\mathrm{A}_{2}$ e CH de Thielaviopsis basicola. Piracicaba, 2004

\begin{tabular}{cccc}
\hline Causas da Variação & GL & QM & F \\
\hline Cultivar & 5 & 1,109537 & $34,35^{* *}$ \\
Inóculo & 1 & 0,828646 & $25,66^{* *}$ \\
Cultivar x Inóculo & 5 & 0,244018 & $7,56^{* *}$ \\
Resíduo & 48 & 0,032298 & \\
Total & 59 & & \\
\hline
\end{tabular}

**Significativo ao nível de significância $\alpha=0,01$. 
APÊNDICE 14. Resumo da análise de variância para comparação entre cultivar, inóculo e sua interação, dos parâmetros comprimento e massa fresca da planta, no ensaio de reação varietal aos isolados $\mathrm{A}_{2}$ e $\mathrm{CH}$ de Thielaviopsis basicola. Piracicaba, 2004

\begin{tabular}{cccccc}
\hline Causas da Variação & GL & \multicolumn{2}{c}{ Comprimento } & \multicolumn{2}{c}{ Massa Fresca } \\
& & QM & F & QM & F \\
\hline Cultivar & 5 & 224,524444 & $11,86^{* *}$ & 5466,29931 & $14,87^{* *}$ \\
Inóculo & 2 & 787,811111 & $41,62^{* *}$ & 16938,62820 & $46,07^{* *}$ \\
Cultivar x Inóculo & 10 & 164,744444 & $8,70^{* *}$ & 1248,46506 & $3,40^{* *}$ \\
Resíduo & 72 & 18,927778 & & 367,7042 & \\
Total & 89 & & & & \\
\hline
\end{tabular}

**Significativo ao nível de significância $\alpha=0,01$. 

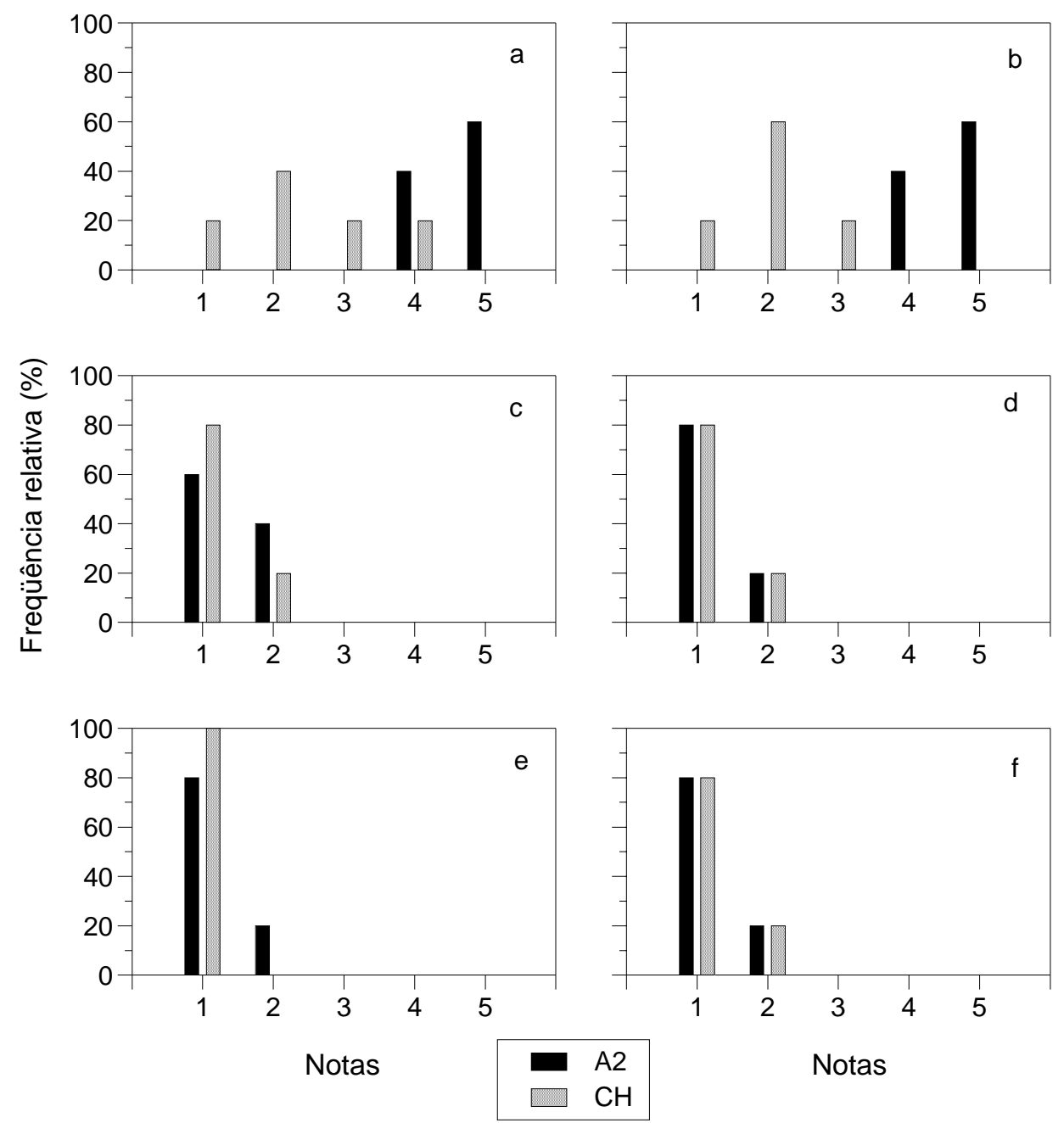

APÊNDICE 15 - Severidade da podridão negra da raiz, ocasionada pelos isolados $\mathrm{A}_{2} \mathrm{e}$ CH, em casa-de-vegetação, nas cultivares de alface: a) Elisa, b) Lucy Brown, c) Raider, d) Warrior, e) Vera e f) New Red Fire 
APÊNDICE 16. Resumo da análise de variância para comparação entre fungicida, dose e sua interação, dos parâmetros porcentagem de inibição do crescimento micelial (PIC) e porcentagem de inibição da esporulação (PIE) do isolado $\mathrm{L}_{1}$, no ensaio de efeito de fungicidas sobre o crescimento micelial e esporulação de Thielaviopsis basicola. Piracicaba, 2003

\begin{tabular}{cccccc}
\hline Causas da Variação & GL & \multicolumn{2}{c}{ PIC } & \multicolumn{2}{c}{ PIE } \\
& & QM & F & QM & F \\
\hline Fungicida & 8 & 1,106974 & $1096,99^{* *}$ & 0,513918 & $1079,43^{* *}$ \\
Dose & 3 & 3,906927 & $3871,70^{* *}$ & 1,705959 & $3583,19^{* *}$ \\
Fungicida x Dose & 24 & 0,157884 & $156,46^{* *}$ & 0,065660 & $137,91^{* *}$ \\
Resíduo & 108 & 0,001009 & & 0,000476 & \\
Total & 143 & & & & \\
\end{tabular}

**Significativo ao nível de significância $\alpha=0,01$. 


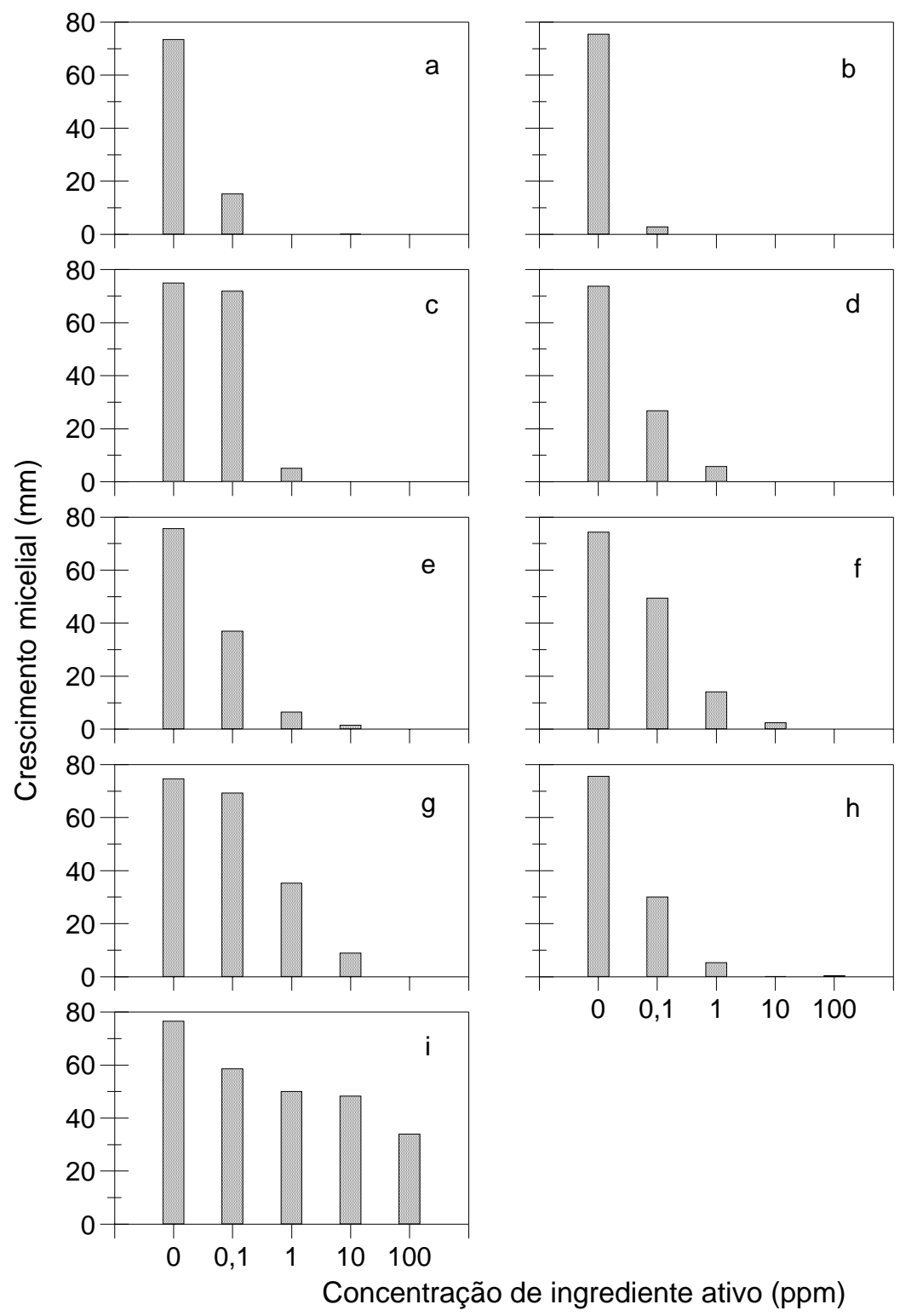

APÊNDICE 17 - Efeito de fungicidas no crescimento micelial do isolado $L_{1}$ de Thielaviopsis basicola. a) benomyl, b) carbendazim, c) tiofanato metílico, d) cyproconazole, e) tebuconazole, f) triadimenol, g) hexaconazole+chlorothalonil, h) propiconazole e i) azoxystrobin 


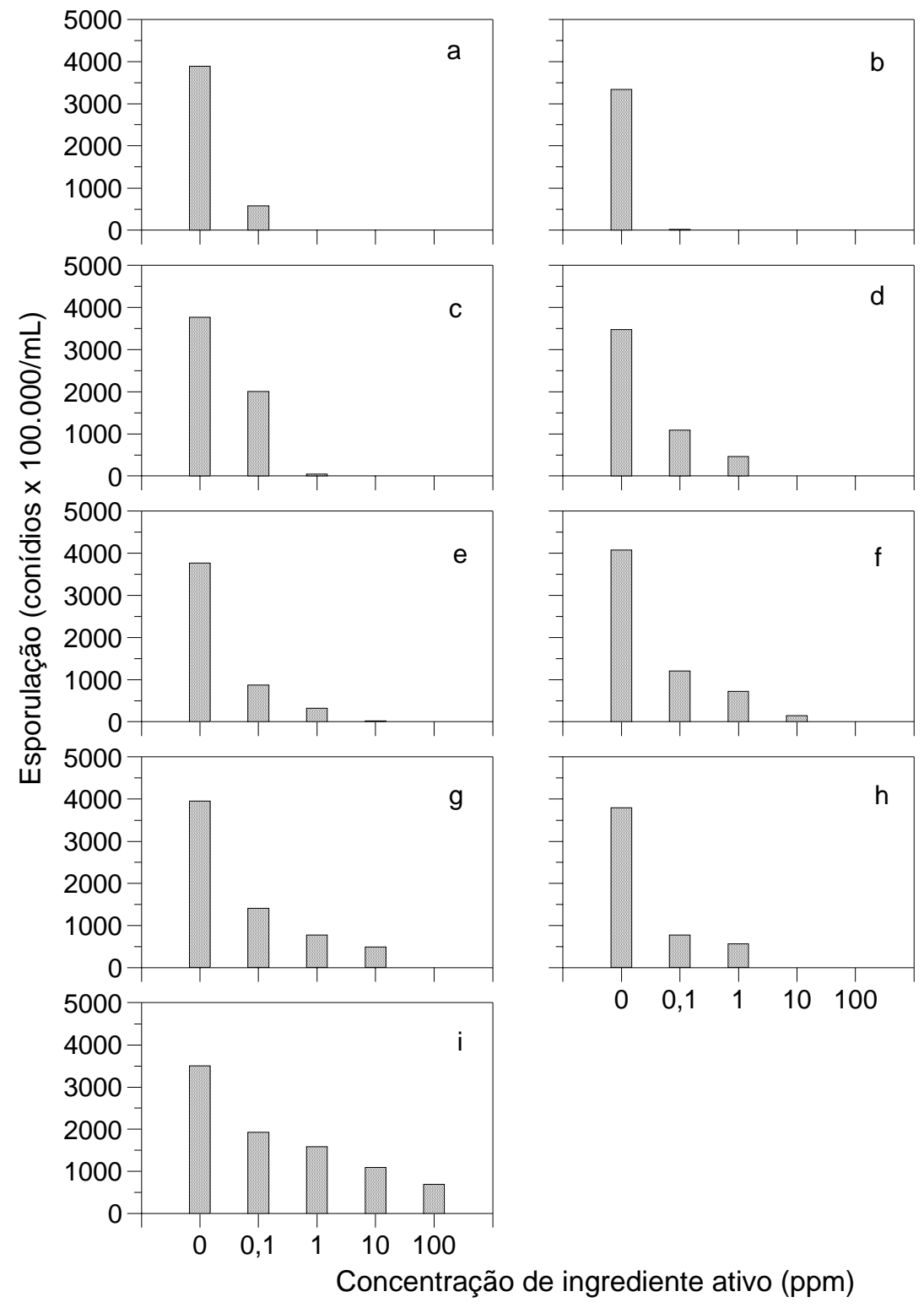

APÊNDICE 18 - Efeito de fungicidas na esporulação do isolado $\mathrm{L}_{1}$ de Thielaviopsis basicola. a) benomyl, b) carbendazim, c) tiofanato metílico, d) cyproconazole, e) tebuconazole, f) triadimenol, g) hexaconazole+chlorothalonil, h) propiconazole e i) azoxystrobin 
APÊNDICE 19. Resumo da análise de variância para comparação entre fungicida, dose, isolado e suas interações, dos parâmetros porcentagem de inibição do crescimento micelial (PIC) e porcentagem de inibição da esporulação (PIE) dos isolados $\mathrm{A}_{2}$ e $\mathrm{CH}$, no ensaio de efeito de fungicidas sobre o crescimento micelial e esporulação de Thielaviopsis basicola. Piracicaba, 2004

\begin{tabular}{|c|c|c|c|c|c|}
\hline \multirow{2}{*}{ Causas da Variação } & \multirow{2}{*}{ GL } & \multicolumn{2}{|c|}{ PIC } & \multicolumn{2}{|c|}{ PIE } \\
\hline & & QM & $\mathbf{F}$ & QM & $\mathbf{F}$ \\
\hline Fungicida & 6 & 0,742648 & $657,78 * *$ & 0,705263 & $585,09 * *$ \\
\hline Dose & 3 & 9,255760 & $8198,06^{* *}$ & 6,745934 & $5596,44 * *$ \\
\hline Isolado & 1 & 0,017575 & $15,57 * *$ & 0,042295 & $35,09 * *$ \\
\hline Fungicida $\mathrm{x}$ Dose & 18 & 0,334944 & $296,67 * *$ & 0,246371 & $204,39 * *$ \\
\hline Fungicida $\mathrm{x}$ Isolado & 6 & 0,009286 & $8,23 * *$ & 0,064452 & $53,47 * *$ \\
\hline Dose $\mathrm{x}$ Isolado & 3 & 0,012312 & $10,91 * *$ & 0,011132 & $9,24 * *$ \\
\hline $\begin{array}{c}\text { Fungicida } \mathrm{x} \text { Dose } \mathrm{x} \\
\text { Isolado }\end{array}$ & 18 & 0,010182 & $9,02 * *$ & 0,040943 & $33,97 * *$ \\
\hline Resíduo & 112 & 0,001129 & & 0,001205 & \\
\hline Total & 167 & & & & \\
\hline
\end{tabular}

**Significativo ao nível de significância $\alpha=0,01$. 


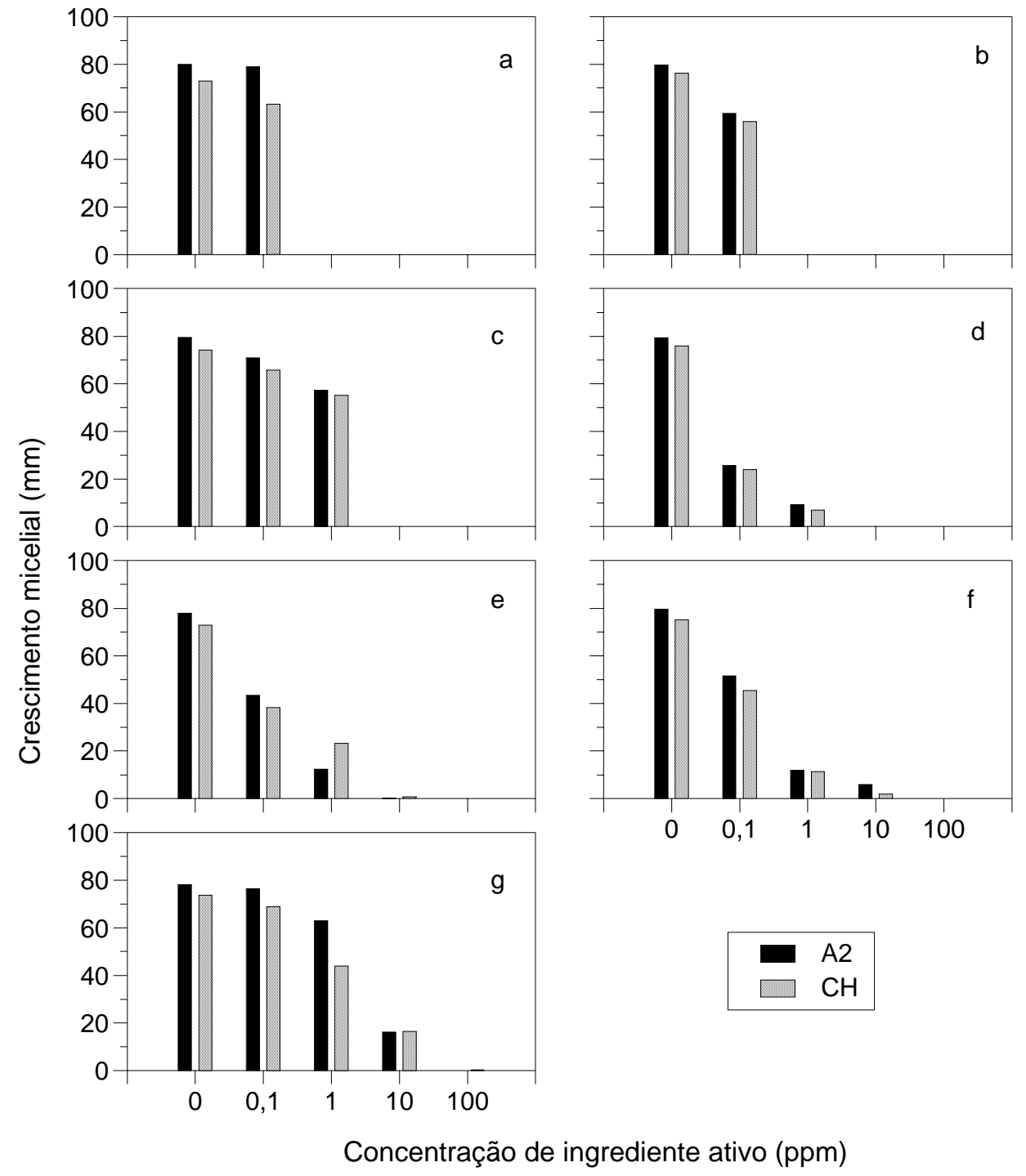

APÊNDICE 20 - Efeito de fungicidas no crescimento micelial dos isolados $\mathrm{A}_{2}$ e $\mathrm{CH}$ de Thielaviopsis basicola. a) benomyl, b) carbendazim, c) tiofanato metílico, d) cyproconazole, e) tebuconazole, f) triadimenol e g) hexaconazole+chlorothalonil 


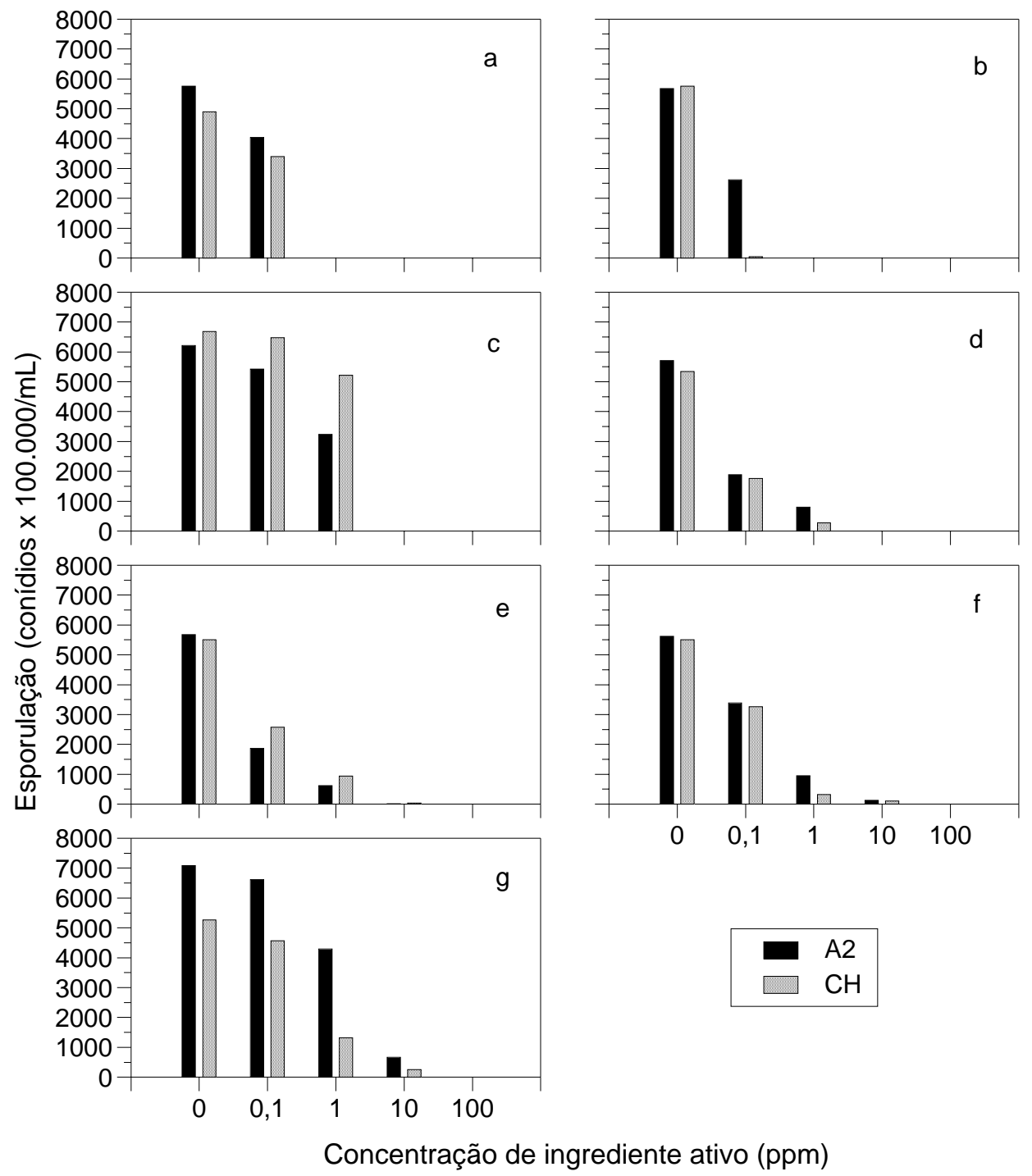

APÊNDICE 21 - Efeito de fungicidas na esporulação dos isolados $\mathrm{A}_{2}$ e $\mathrm{CH}$ de Thielaviopsis basicola. a) benomyl, b) carbendazim, c) tiofanato metílico, d) cyproconazole, e) tebuconazole, f) triadimenol e g) hexaconazole+chlorothalonil 
APÊNDICE 22. Resumo da análise de variância para comparação entre fungicidas, dos parâmetros nota e comprimento da planta, no teste de efeito de fungicidas no controle de Thielaviopsis basicola in vivo. Piracicaba, 2003

\begin{tabular}{cccccc}
\hline \multirow{2}{*}{ Causas da Variação } & GL & \multicolumn{2}{c}{ Nota } & \multicolumn{2}{c}{ Comprimento planta } \\
& & QM & F & QM & F \\
\hline Fungicida & 8 & 0,752832 & $16,36^{* *}$ & 245,5000 & $19,10^{* *}$ \\
Resíduo & 72 & 0,046008 & & 12,8549 & \\
Total & 80 & & & & \\
\end{tabular}

**Significativo ao nível de significância $\alpha=0,01$. 
APÊNDICE 23. Resumo da análise de variância para comparação entre matéria orgânica, solarização e sua interação, dos parâmetros nota, comprimento e massa fresca da planta, no ensaio de efeito da solarização com e sem incorporação de matéria orgânica no controle de Thielaviopsis basicola em alface. Piracicaba, 2004

\begin{tabular}{cccccccc}
\hline Causas da Variação & GL & \multicolumn{2}{c}{ Nota } & \multicolumn{2}{c}{ Comprimento } & \multicolumn{2}{c}{ Massa Fresca } \\
& & QM & F & QM & F & QM & F \\
\hline Matéria orgânica (MO) & 2 & 0,069094 & $2,57^{\text {ns }}$ & 56,835605 & $21,22^{* *}$ & 0,316170 & $114,77^{* *}$ \\
Solarização (S) & 1 & 1,244978 & $46,24^{* *}$ & 75,932272 & $28,35^{* *}$ & 0,717465 & $260,44^{* *}$ \\
MO x S & 2 & 0,049255 & $1,83^{\mathrm{ns}}$ & 12,758938 & $4,76^{*}$ & 0,052827 & $19,18^{* *}$ \\
Resíduo & 12 & 0,026923 & & 2,678494 & & 0,002754 & \\
Total & 17 & & & & & &
\end{tabular}

*Significativo ao nível de significância $\alpha=0,05$.

**Significativo ao nível de significância $\alpha=0,01$. 


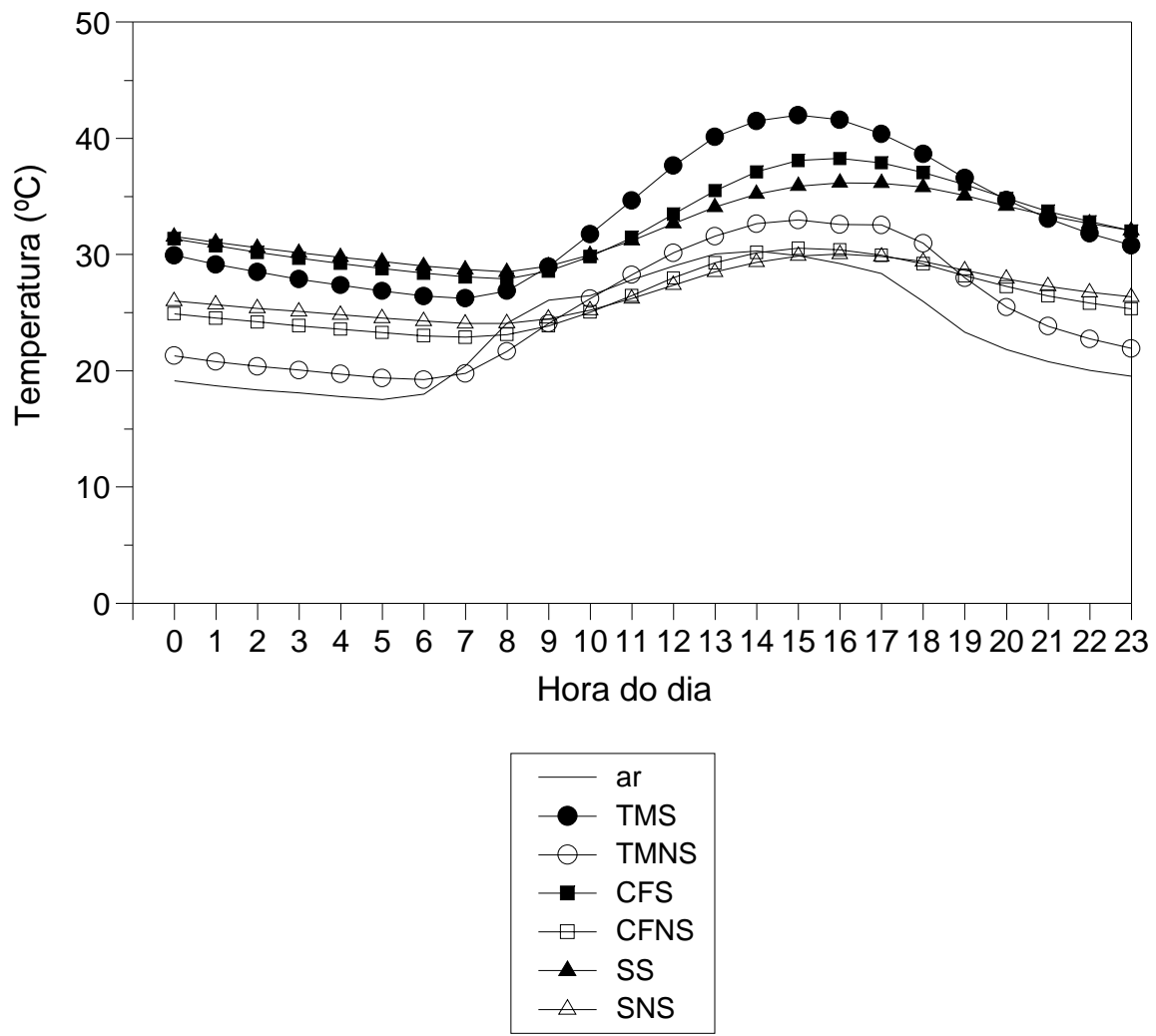

APÊNDICE 24 - Temperaturas médias do solo registradas durante o período de solarização para os diferentes tratamentos: TMS (incorporação de torta de mamona / solarizado), TMNS (incorporação de torta de mamona / não solarizado), CFS (incorporação de cama de frango / solarizado), CFNS (incorporação de cama de frango / não solarizado), SS (substrato sem incorporação de matéria orgânica / solarizado) e SNS (substrato sem incorporação de matéria orgânica / não solarizado) 
APÊNDICE 25. Análise química dos substratos submetidos aos diferentes tratamentos no ensaio de efeito da solarização com e sem incorporação de matéria orgânica no controle de Thielaviopsis basicola em alface

\begin{tabular}{ccccccc}
\hline \multirow{2}{*}{ Parâmetro } & \multicolumn{2}{c}{ Torta Mamona } & \multicolumn{2}{c}{ Cama Frango } & \multicolumn{2}{c}{ Substrato } \\
& $\mathbf{N S}^{\mathbf{1}}$ & $\mathbf{S}^{\mathbf{2}}$ & $\mathbf{N S}$ & $\mathbf{S}$ & $\mathbf{N S}$ & $\mathbf{S}$ \\
\hline $\mathrm{pH}\left(\mathrm{CaCl}_{2}\right)$ & 4,5 & 5,0 & 4,7 & 4,7 & 4,7 & 4,8 \\
$\mathrm{MO}\left(\mathrm{g} / \mathrm{dm}^{3}\right)$ & 153 & 162 & 170 & 165 & 156 & 153 \\
$\mathrm{~N}\left(\mathrm{~g} / \mathrm{dm}^{3}\right)$ & 6 & 7 & 4 & 6 & 5 & 6 \\
$\mathrm{P}\left(\mathrm{mg} / \mathrm{dm}^{3}\right)$ & 211 & 271 & 251 & 281 & 216 & 244 \\
$\mathrm{~K}\left(\mathrm{mmol} / \mathrm{dm}^{3}\right)$ & 2,3 & 5,9 & 5,4 & 5,6 & 3,6 & 5,5 \\
$\mathrm{Ca}\left(\mathrm{mmol} / \mathrm{dm}^{3}\right)$ & 91 & 113 & 123 & 110 & 107 & 110 \\
$\mathrm{Mg}\left(\mathrm{mmol} / \mathrm{dm}^{3}\right)$ & 36 & 52 & 48 & 48 & 40 & 40 \\
$\mathrm{H}+\mathrm{Al}\left(\mathrm{mmol} / \mathrm{dm}^{3}\right)$ & 80 & 58 & 80 & 64 & 64 & 64 \\
$\mathrm{SB}\left(\mathrm{mmol} / \mathrm{dm}^{3}\right)$ & 129,3 & 170,9 & 176,4 & 163,6 & 150,6 & 155,5 \\
$\mathrm{~V}(\%)$ & 62 & 75 & 69 & 72 & 70 & 71 \\
$\mathrm{~m}(\%)$ & 2 & 0 & 1 & 1 & 1 & 1 \\
\hline
\end{tabular}

${ }^{\mathrm{Não}}$ Solarizado

${ }^{2}$ Solarizado 